\title{
A SPATIAL AND TEMPORAL ANALYSIS OF ALGAE IN THE RIDEAU CANAL, ONTARIO, CANADA
}

\author{
by \\ Lindsay Louise Trottier
}

A thesis submitted to the Faculty of Graduate and Postdoctoral Affairs in partial fulfillment of the requirements for the degree of

Master of Science

in

Geography

Carleton University

Ottawa, Ontario

(C) 2021

Lindsay Louise Trottier 


\begin{abstract}
Human activity causes various negative impacts on freshwater ecosystems. The Rideau Canal, and its watersheds, in Ontario, Canada is a freshwater ecosystem altered by humans which faces pressure from nutrient loading, land-use change, and invasive species. This thesis examined spatial and temporal drivers of algal abundance, biomass, and community composition in the Rideau Canal. First, the chemical and biological changes that have occurred since 1995 were quantified by comparing water samples and periphyton biomass collected in 1995 and 2019. This study found that periphyton biomass, despite experiencing changes in its environment, demonstrated little temporal variation. Second, environmental, spatial, and temporal drivers of phytoplankton abundance, biomass, and community composition in the Rideau Canal in 2019 were quantified using a FlowCam to enumerate and identify the phytoplankton. This study showed that phytoplankton community composition in the waterway is largely driven by environmental factors, with spatial and temporal controls having lesser effects.
\end{abstract}




\section{PREFACE}

Chapter 3 will be submitted for publication to the Canadian Journal of Fisheries and Aquatic Sciences. I was the lead investigator for this project, and responsible for overall project conceptualization, data collection, analysis, curation, and visualization, and writing of the original draft of the manuscript. John Chételat assisted in project conceptualization and methodology and reviewed the manuscript. Chantal Vis was involved with funding acquisition and reviewed the manuscript. Paul B. Hamilton also contributed to the review of the manuscript. Frances R. Pick assisted in project conceptualization and methodology, and reviewed the manuscript. Jesse C. Vermaire supervised the project, and was involved with funding acquisition, conceptualization, and reviewed the manuscript.

Chapter 4 will also be submitted for publication in the journal Freshwater Biology. I was the lead investigator for this project, and responsible for overall project conceptualization, data collection, analysis, curation, and visualization, and writing of the original draft of the manuscript. Adam K. J. Williamson assisted with data analysis and reviewed the manuscript. Paul B. Hamilton assisted with project conceptualization and methodology and reviewed the manuscript. Chantal Vis was involved with funding acquisition and reviewed the manuscript. Jesse $C$. Vermaire supervised the project, and was involved with funding acquisition, conceptualization, and reviewed the manuscript.

\section{Lindsay L. Trottier}

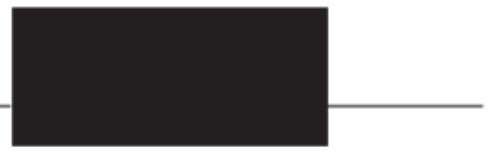

August 2, 2021

Signature

Date

We are in agreement with the above contribution statement.

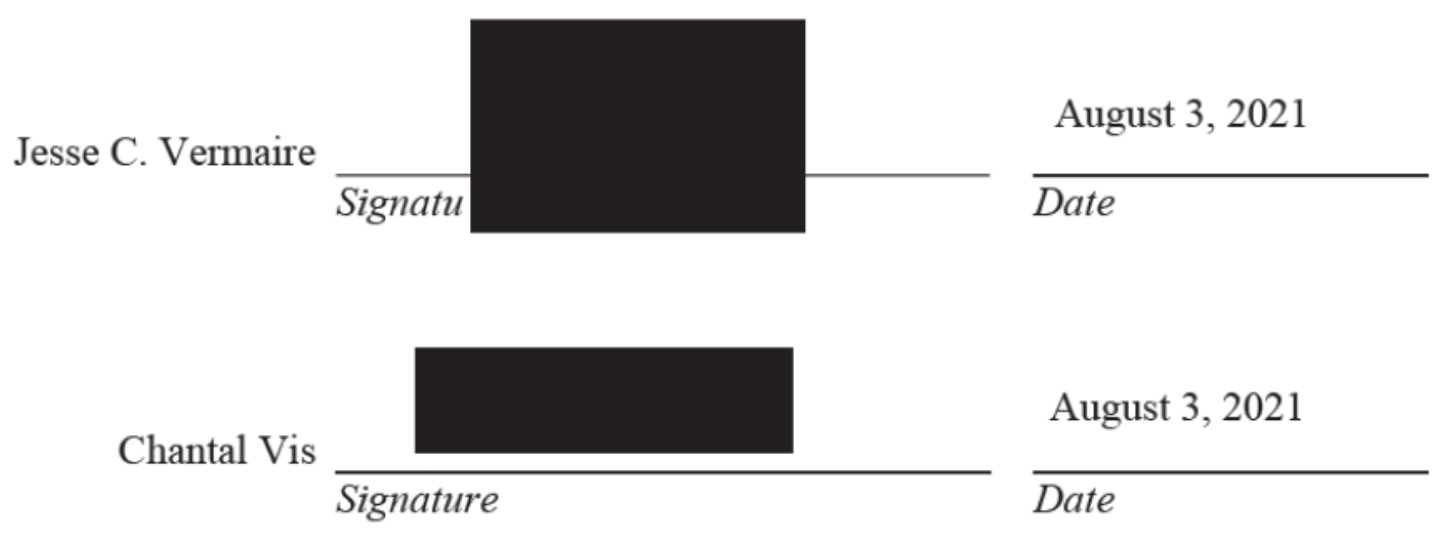




\section{ACKNOWLEDGEMENTS}

Who would have thought I would be completing my master's degree during a global pandemic? This would not have been possible without the support of my supervisors, mentors, friends, and family.

I would like to take this opportunity to thank Dr. Jesse Vermaire for his support, helpful comments, and for reminding me that while a p-value of 0.056 is not significant, it's close. I am also thankful for the helpful comments, feedback, and perspectives provided by Dr. Chantal Vis. I am extremely appreciative of Paul Hamilton's expertise in phytoplankton identification and patience to respond to my many questions and e-mails. I also want to thank Adam Williamson for his tremendous help sorting through phytoplankton particles with me.

I want to thank Kayla McIntee, Emma Stockton, Patrick Beaupre, and Madelaine Bourdages for always being there for me: whether that involved "talking it out" or accompanying me for a much-needed beverage.

I am grateful to my siblings, Kayleigh, Hayden, and Camryn Trottier, for their love and ability to help me see the humour in everything. I am especially thankful of my aunt and grandma, Louise and Jessie Griffin, for their love and for always reminding me of the bigger picture. Last but not least, I would like to thank my mum and dad, Gillian and Daniel Trottier, for their love and encouragement, and for supporting me while I do whatever makes me happy. 


\section{TABLE OF CONTENTS}

ABSTRACT ........................................................................................................................

PREFACE ...............................................................................................................ii

ACKNOWLEDGEMENTS .......................................................................................iv

TABLE OF CONTENTS ...................................................................................... v

LIST OF TABLES .............................................................................................................. vii

LIST OF FIGURES ..............................................................................................iii

LIST OF APPENDICES .............................................................................................. $\mathrm{x}$

1 INTRODUCTION ............................................................................................... 1

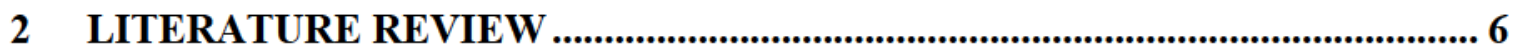

2.1 HUMAN IMPACTS ON FRESHWATER ECOSYSTEMS _............................. 6

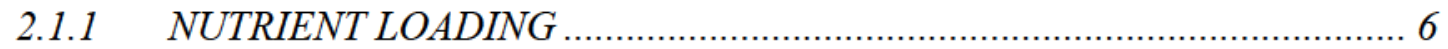

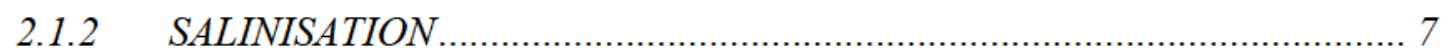

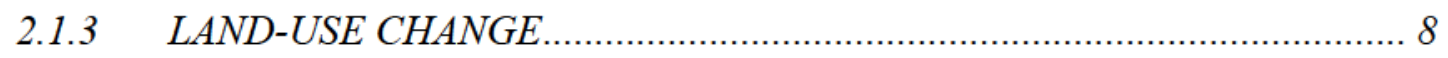

2.1.4 PHYSICAL ALTERATIONS OF HYDROLOGIC FLOWS …………….... 9

2.1.5 INTRODUCTION OF INVASIVE SPECIES …………….................... 10

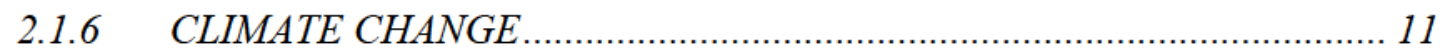

2.1.7 CUMULATIVE EFFECTS OF MULTIPLE STRESSORS ….................... 12

2.2 ALGAE IN LACUSTRINE AND RIVERINE ECOSYSTEMS ........................ 13

2.3 MONITORING CHANGES IN FRESHWATER ECOSYSTEMS WITH

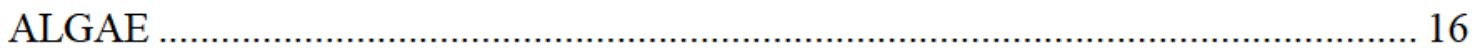

2.4 GEOGRAPHY OF THE RIDEAU CANAL …………………………..... 17

2.5 DRIVERS OF ALGAL BIOMASS AND COMMUNITY COMPOSITION IN

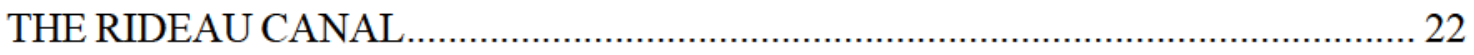

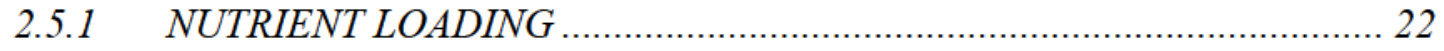

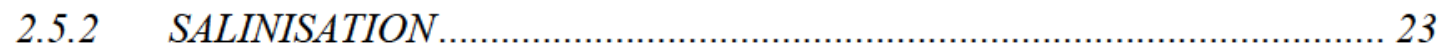

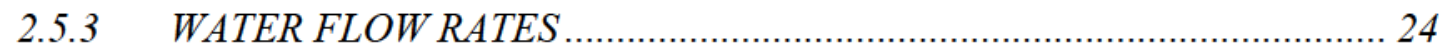

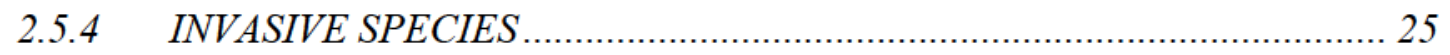

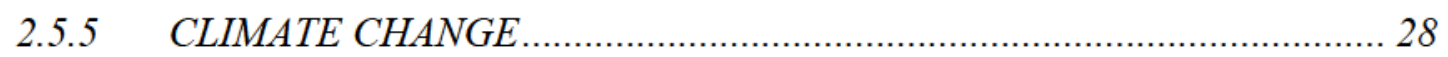

3 WATER CHEMISTRY AND PERIPHYTON BIOMASS IN THE RIDEAU RIVER: HAVE CONCENTRATIONS CHANGED AFTER 24 YEARS? ................ 30

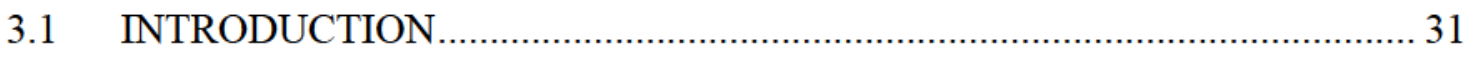

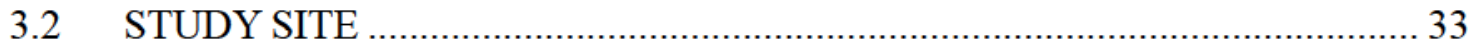

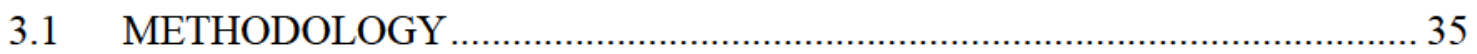

3.2 RESULTS

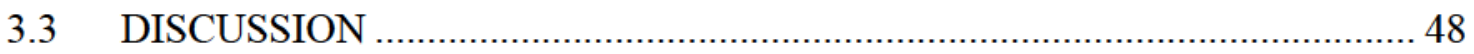




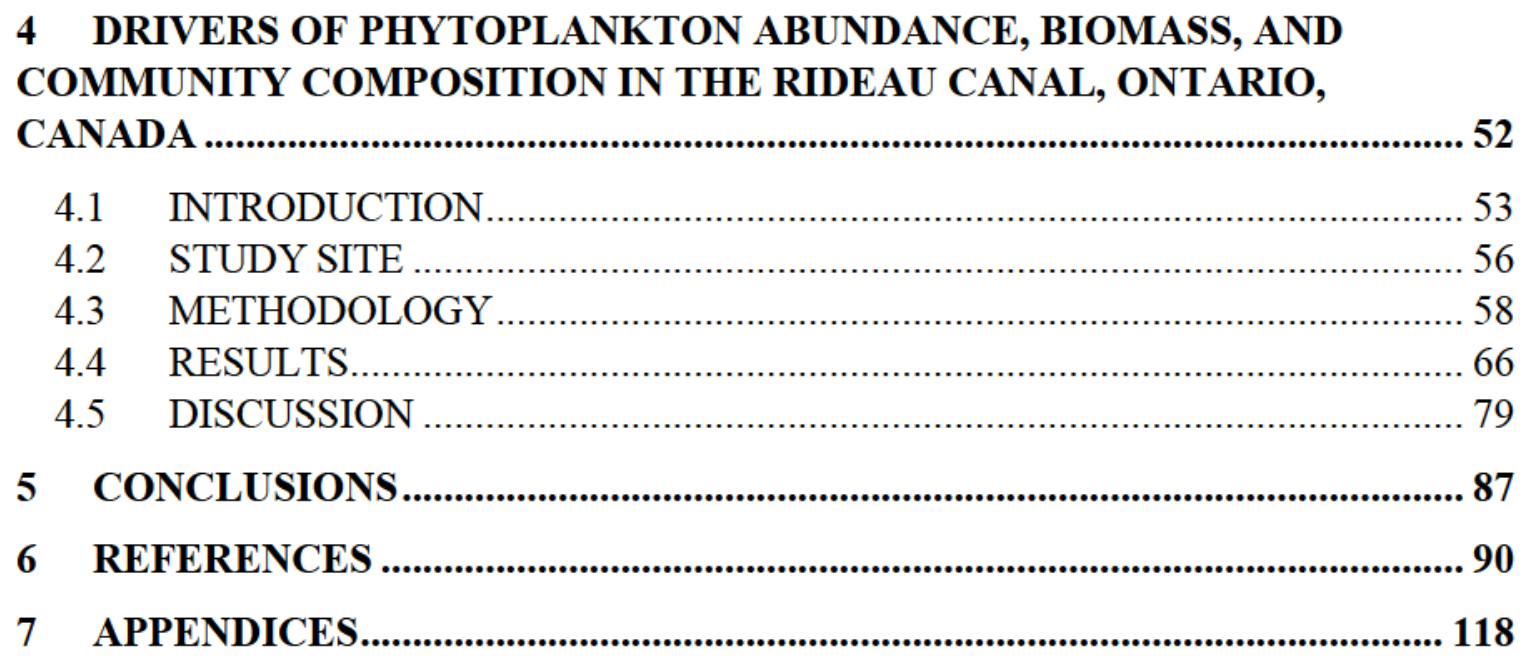




\section{LIST OF TABLES}

Table 3-1. Comparison of biological, chemical, and physical parameters (mean $\pm \mathrm{SE}$ ) and sample sizes (n) between data collected in 1995 (Chételat et al. 2000) and 2019.... 43

Table 4-1. The mean ( \pm s.d.) environmental and water chemistry characteristics of the monthly $(1-6)$ and grab-sample (A, B) sites by month.

Table 4-2. Correlation matrix of environmental variables, and significant principal component axes. Bold indicates p-values $<0.05$ and underline indicates p-values $<0.001$. 


\section{LIST OF FIGURES}

Figure 2-1. Map of the Rideau Canal in Ontario, Canada with the Rideau River (north) and the Cataraqui River - St. Lawrence River (south) tertiary watersheds outlined in dark blue. The quaternary watersheds that drain into the Rideau River and Cataraqui River are outlined in light blue. Map created in ArcGIS Pro 2.1.0 using geospatial data acquired from Natural Earth (2018), Natural Resources Canada (2017), and Ontario Ministry of Natural Resources and Forestry (OMNRF; 2020)......

Figure 2-2. Examples of harmful algal blooms in the Rideau Canal. A) Kingston Mills lock station B) Dog Lake C) downtown Ottawa D) Kingston Mills lock station.

Figure 3-1. Map showing the seven sample sites (stars, 1-7), the six Provincial Water Quality Monitoring Network stations (squares, A-F), and anthropogenic land-use change from 2000 to 2015 (pink) along the Rideau River in Ontario, Canada. Map created in ArcGIS Pro 2.1.0 using geospatial data acquired from Natural Earth (2018), Natural Resources Canada (2017), and Ontario Ministry of Natural Resources and Forestry (OMNRF; 2019).

Figure 3-2. The relationship between chlorophyll-a concentration calculated with a trichromatic equation (chlorophyll-a $=11.85 \mathrm{E}_{664}-1.54 \mathrm{E}_{647}-0.08 \mathrm{E}_{630}$; Jefferey and Humphrey 1975) and with a monochromatic equation (chlorophyll-a $=29.5 \mathrm{E} 665$; Lorenzen 1967; Wintermans and De Mots 1965).

Figure 3-3. The concentration of total phosphorus (a), chloride (b) and total nitrogen (c) at the six provincial water quality monitoring stations (A-F) in the Rideau River in Ontario, Canada between 2000 and 2018 with trendlines showing significant relationships. Stations are in order from upstream to downstream (top-right to bottomleft). Data acquired from the Ontario Provincial (Stream) Water Quality Monitoring Network (OMECC 2018). a) Station C: $\mathrm{r}^{2}=0.060, \mathrm{p}=0.0017$; Station D: $\mathrm{r}^{2}=0.031, \mathrm{p}=$ 0.029. b) Station C: $\mathrm{r}^{2}=0.16, \mathrm{p}=9.40 \times 10^{-7}$; Station $\mathrm{D}: \mathrm{r}^{2}=0.15, \mathrm{p}=3.31 \times 10^{-6}$; Station F: $r^{2}=0.030, p=0.041$. c) Station A: $r^{2}=0.049, p=0.013$; Station B: $r^{2}=0.036$, $\mathrm{p}=0.036$; Station $\mathrm{E}: \mathrm{r}^{2}=0.12, \mathrm{p}=6.73 \times 10^{-5}$.

Figure 3-4. The log concentration of chlorophyll-a (open circles, dashed line) and ashfree dry mass (AFDM; black triangles, solid line) with trendlines with respect to total phosphorus collected in the Rideau River, Ontario, Canada in 2019. Each point provides the mean chlorophyll-a or ash-free dry mass for eight rocks at each site on one sampling date (June 4 or August 2, 2019), and the mean total phosphorus concentration of three water samples collected at each site on the corresponding sampling date (June 4 or August 2, 2019). Chlorophyll-a: $\mathrm{r}^{2}=0.14, \mathrm{p}=0.19$; AFDM: $\mathrm{r}^{2}=0.15, \mathrm{p}=0.17$. 
Figure 3-5. The log concentration of total phosphorus (A), conductivity (B), log concentration of chlorophyll-a (C), and log ash-free dry mass (D) with trendlines in 1995 (open circles, dashed line; Chételat et al. 2000) and 2019 (black triangles, solid line) with respect to distance downstream in the Rideau River in Ontario, Canada. A) 1995: $\mathrm{r}^{2}=$ $0.12, \mathrm{p}=0.065 ; 2019: \mathrm{r}^{2}=0.082, \mathrm{p}=0.14$. B) $1995: \mathrm{r}^{2}=0.93, \mathrm{p}=0.00045 ; 2019 ; \mathrm{r}^{2}=$ 0.86, $\mathrm{p}=0.0026$. C) $1995: \mathrm{r}^{2}=0.071, \mathrm{p}=0.0046 ; 2019: \mathrm{r}^{2}=0.028, \mathrm{p}=0.078$. D) 1995: $\mathrm{r}^{2}=0.086, \mathrm{p}=0.0017,2019: \mathrm{r}^{2}=0.00011, \mathrm{p}=0.91$

Figure 4-1. Map of the Rideau waterway in Ontario, Canada from Ottawa to Kingston with six monthly sample sites (stars; $1-6$ ) and two grab sample sites (squares; A, B). The total number of phytoplankton living units per $\mathrm{mL}$ counted in each of the eight key phytoplankton classes at monthly sample sites between June and August 2019 are presented. Map created in ArcGIS Pro 2.1.0 using geospatial data acquired from Natural Earth (2018) and Natural Resources Canada (2017).

Figure 4-2. FlowCam images demonstrating the diversity of phytoplankton living units in each of the eight key phytoplankton classes. Scale bars (red) represent $100 \mu \mathrm{m}$. 64

Figure 4-3. Physical and chemical characteristics of water quality (mean \pm s.d.) collected at monthly (1 - 6) and grab (A, B) sample sites from June to August 2019.

Figure 4-4. Relative abundance (\%) of each of the eight key classes of phytoplankton at monthly (1 - 6) and grab (A, B) sample sites between June and August 2019.

Figure 4-5. A comparison of the average number of phytoplankton living units per $\mathrm{mL}$ (grey bars; \pm s.d.) and average concentrations (black points; \pm s.d.) of total phosphorus ( $\mu \mathrm{g} / \mathrm{L}$; top row), total Kjeldahl nitrogen $(\mathrm{mg} / \mathrm{L} ;$ middle row), and chlorophyll-a $(\mu \mathrm{g} / \mathrm{L}$; bottom row) in monthly (1 - 6) and grab (A, B) samples between June and August 2019.

Figure 4-6. Principal component analysis (PCA) of the most common phytoplankton groups by sample site. Sites are presented by month (purple $=$ June, blue $=$ July, green $=$ August) in panel A using PCA scaling 1, and phytoplankton groups are presented in panel B using PCA scaling 2. PCA axis 1 represents $21.94 \%$ of the variance explained, while PCA axis 2 represented $15.16 \%$ of the variance explained. Abbreviated and full phytoplankton sub-group names are provided in Table 7-1

Figure 4-7. Variance partitioning of the most common phytoplankton groups at each site using redundancy and partial redundancy analyses. The proportion of variance explained by environmental variables (temperature, logConductivity, oxygen concentration, $\mathrm{pH}$, total phosphorus, and dissolved organic carbon), distance of sample site from Ottawa, month in which the sample was collected, and residual variance are presented as percentages (\%). All testable proportions are significant with p-values $<0.02$. 


\section{LIST OF APPENDICES}

Table 7-1. Abbreviated names of phytoplankton sub-groups used in PCA plot (Figure 4-

6). 118 


\section{INTRODUCTION}

Humans have been noticeably and irreversibly altering the global climate and ecosystems for the past 200 years (e.g., Ricciardi and Macisaac 2010; Abram et al. 2016). Along with climate change, humans have profoundly impacted freshwater ecosystems through nutrient loading, land-use change and urbanization, physical alterations to hydrologic flows, overexploitation, salinisation, light and noise pollution, and the introduction of invasive species (Carpenter et al. 2011; Reid et al. 2019). Individually, the impact of each of these drivers may be considerable but together, the cumulative effects of multiple stressors on aquatic ecosystems and species can be devastating (Schindler 2001; Su et al. 2021). Human reliance on fresh water for industrial and residential uses can exacerbate negative impacts on freshwater ecosystems, which increases the need to monitor these changes and manage freshwater resources in a sustainable way (Revenga et al. 2005).

Algae can be found free-floating in the water (phytoplankton), attached to the surface of rooted aquatic plants (epiphyton) and rocks (periphyton), and anchored to littoral substrates (e.g., genus Chara). Aside from their location in aquatic ecosystems, a key difference between phytoplankton and periphyton is their reliance on light and nutrients for growth. As phytoplankton are suspended in the water column, they generally have superior access to light but have a tendency toward nutrient limitation, whereas benthic periphyton have easier access to nutrients released from the sediment but are limited by light availability (Hansson 1988). This difference drives competition between the two algae, with phytoplankton dominating ecosystems with high nutrient 
concentrations, and periphyton and rooted aquatic plants (macrophytes) dominating clearwater and shallow aquatic ecosystems (Sand-Jensen and Borum 1991).

Changes in freshwater ecosystems are primarily monitored using chemical analyses and biological indicator (bioindicator) species of bacteria, macroinvertebrates, and algae that are sensitive to changes in their environment (Bonada et al. 2006; Friberg et al. 2011). Algae, in particular, are important indicators of the status of freshwater ecosystems for a number of reasons (McCormick and Cairns 1994). First, algae are abundant and omnipresent in freshwater ecosystems. Both attached and free-floating algae provide useful information about the environment, and their widespread availability makes monitoring accessible and cost-effective (Collins and Weber 1978; Whitton and Kelly 1995). Second, algal biomass and community composition are driven by chemical, physical, and biological aspects of the environment. Phosphorus, nitrogen, water flow rates, water residence time, temperature, light availability, competitive interactions, grazing, and the presence of aquatic invasive species all have impacts on algae in freshwater ecosystems (Biggs and Close 1989; Reynolds 1989; Schindler 1971; Tilman 1977; Walsh et al. 2016). As a result, monitoring changes in algal biomass and community is essential for quantifying spatial and temporal trends in water quality, and characterizing the overall status of an ecosystem (Ibelings et al. 1998; Lorenz et al. 1997). Third, algae have an important role in aquatic food webs, acting as a nutrient-rich food source for planktivorous fish, zooplankton, and macroinvertebrates (Brett et al. 2009; Vadeboncoeur and Power 2017). Changes to algae biomass can elicit impacts on other trophic levels of aquatic food webs, causing whole-system shifts (Scheffer et al. 1993). The opposite also holds true, where impacts on other trophic levels of freshwater 
ecosystems also cause changes to algal communities (Simon and Townsend 2003; Timms and Moss 1984; Walsh et al. 2016).

One result of human impacts on freshwater ecosystems is the noticeable accrual of algae; a phenomenon called algal blooms (Reynolds and Walsby 1975). Harmful algal blooms are those which have harmful impacts on ecosystems and on the humans and animals that interact with them, through the release of toxins or changes to the odour, taste, or clarity of the water (Carmichael 2001; Paerl et al. 2001). The formation of harmful algal blooms has been associated with widespread nutrient loading (eutrophication), climate change, and the introduction of invasive species like Dreissena polymorpha (zebra mussels; Knoll et al. 2008; Paerl et al. 2011). The prevalence of harmful algal blooms is increasing globally (Hallegraeff 1993), and in Ontario specifically (Winter et al. 2011a), which reinforces the need for further research on the drivers of algal composition and abundance as well as management approaches (Brooks et al. 2016).

The Rideau Canal in Ontario, Canada is a National Historic Site and UNESCO world heritage site built between 1826 and 1832, with significant ecological, cultural, and socioeconomic importance (Ballinger 1994; Bergmann et al. 2021; Parks Canada 2021). This $202-\mathrm{km}$ long waterway connects the Ottawa River to Lake Ontario via the Rideau and Cataraqui rivers, which flow through a series of lakes in the Rideau Lakes region of Ontario, Canada. The Rideau Canal was designated as a Canadian Heritage River by the Canadian Heritage Rivers System in 2000 and a World Heritage Site by the United Nations Educational, Scientific and Cultural Organization (UNESCO) in 2007. 
Paleolimnological analyses have shown that several lakes forming the Rideau Canal were oligo-mesotrophic before European settlements formed, then had large changes in the diatom community composition as a result of increasing nutrient concentrations until the 1970s, at which point nutrients began to decline again (Christie and Smol 1996; Forrest et al. 2003; Sonnenburg et al. 2009). However, local residents, lake associations, and users of the waterway have voiced their growing concerns about the deteriorating water quality and prevalence of harmful algal blooms in the Rideau Canal resulting from increased temperatures and decreased water flow rates in recent years (Mistry et al. 2021; Pick 2016).

Algae in the Rideau River were the subject of many studies in the 1990s and 2000s, with a focus on phytoplankton (Basu and Pick 1997, 1995; Chételat et al. 2000; Hamilton et al. 2012, 2011; Poulin 2001; Vidal et al. 2004; Yang et al. 1997). However, algae abundance, biomass, and community composition of the Rideau River has not been studied recently, nor have the algae of the two rivers composing the Rideau Canal, the Rideau and Cataraqui rivers, been studied together. With recent reports of poor water quality and harmful algal blooms in the Rideau Canal, it is important that environmental, temporal, and spatial trends of algae are quantified to better understand which factors are driving the changes in algal biomass and community composition. This information can help inform the many partners, stakeholders, decision-makers, and users of the Rideau Canal of the specific impacts human activities have on this important heritage waterway, which will enhance management plans and improve water quality (Bergman et al. 2021).

The overall objective of this thesis was to analyse the environmental (biological, chemical, and physical), temporal, and spatial drivers of algal abundance and community 
composition in the Rideau Canal. This research is the first to use algal biomass measurements in combination with fluid imaging microscopy (FlowCam) to quantify algal abundance and identify phytoplankton community composition in the Rideau Canal. To meet the overarching research objective, I specifically:

1. Examined periphyton biomass in the Rideau River to quantify biological and chemical changes that have occurred since 1995 in response to environmental conditions (Chapter 3); and,

2. Examined phytoplankton abundance, biomass, and community composition using a FlowCam, and quantified the importance of environmental, spatial, and temporal variables on phytoplankton community composition in the Rideau Canal (Chapter 4).

This thesis has been prepared in the integrated thesis format. An in-depth review of the literature pertaining to human impacts on freshwater ecosystems and algae, and the geography of the Rideau Canal are discussed in Chapter 2. In Chapter 3, a temporal and spatial analysis of riverine periphyton biomass and water quality are examined, using data collected in 1995 and 2019, along a 70-km stretch of the Rideau River. A seasonal and spatial analysis of phytoplankton biomass, abundance, and community composition along the length of the Rideau Canal in 2019 is presented in Chapter 4. The key findings, future directions, and conclusions are discussed in Chapter 5, with supplemental information provided in the appendix. 


\section{LITERATURE REVIEW}

Since the beginning of the industrial era in the mid-1700s, humans have dramatically altered both terrestrial and aquatic ecosystems. In freshwater ecosystems, the human (anthropogenic) stressors are numerous, have varying effects on chemical, physical, and biological aspects of the ecosystem, and ultimately affects the biodiversity of species (Dudgeon et al. 2006). In the past 50 years, 3741 freshwater populations have declined by $84 \%$ on average (WWF 2020). One third of all freshwater species face extinction, and biodiversity in lotic habitats (i.e., rivers, streams) is more threatened than that of species in lentic habitats (i.e., lakes, wetlands; Sala et al. 2000; Collen et al. 2014).

Documenting changes in biodiversity as a result of human impacts is essential for understanding the severity of the changes and for identifying approaches to conserve and protect species (Reid et al. 2019). Human activity in and near freshwater ecosystems may have negative impacts such as the excess input of nutrients and salts, land-use change, alteration to water flows and connectivity, decreases in dissolved oxygen, and the introduction of invasive species (Carpenter et al. 2011; Dudgeon et al. 2006; Jane et al. 2021; Reid et al. 2019; Strayer and Dudgeon 2010).

\subsection{HUMAN IMPACTS ON FRESHWATER ECOSYSTEMS}

\subsubsection{NUTRIENT LOADING}

Eutrophication occurs as a result of excess nutrient loading, mainly phosphorus and nitrogen, into an aquatic ecosystem (Burkholder 2000). Phosphorus and nitrogen may enter an ecosystem from point (direct) and nonpoint (indirect) sources. Common point sources include runoff from industrial sites, wastewater effluent, and stormwater overflows, and nonpoint sources of nutrients include runoff from agricultural fields, 
construction sites, and urban land, septic leachate, and atmospheric deposition of nutrients into water (Novotny and Olem 1994). Nonpoint sources are responsible for a large proportion of nutrient loading into fresh water, whereas point sources are more easily located and managed (Carpenter et al. 1998).

Nutrient loading is an issue faced by both fresh water and coastal ecosystems globally (Smith 2003). In fresh water, eutrophication may result in increased algal biomass (Janus and Vollenweider 1981; Schindler 1971), changes in the species composing the algal community (Anderson et al. 2002; Schindler et al. 1971), decreased water clarity and oxygen concentration (Foley et al. 2012; Lathrop et al. 1996), an unpleasant taste, smell, and/or appearance of water (Paerl et al. 2001), and a loss of economic benefits stemming from recreational uses and property sales (Dodds et al. 2009).

\subsubsection{SALINISATION}

Salinisation refers to the increasing concentration of inorganic ions, mainly chloride and sodium (Williams 1987). These salts may accumulate naturally from rainwater and may leach into fresh water through the weathering of the surrounding terrestrial land (primary salinisation; Williams 2001). Human activities that cause anthropogenic (secondary) salinisation of fresh water include the application of salts for road de-icing, mining, clearing and irrigating land for agricultural use, and increasing impervious surfaces in residential and urban areas (Cañedo-Argüelles et al. 2013; Kaushal et al. 2005). The secondary salinisation of inland waters was first noted as a concern in arid and semi-arid regions under pressure from farming (Williams 1987), but has more recently been observed in humid continental regions in the northern United States (Corsi et al. 2015; Kaushal et al. 2005), and across Canada (Kerr 2017; Winter et al. 2011b). 
In Canada, over four million tonnes of chloride salts (sodium chloride, calcium chloride, magnesium chloride, and potassium chloride) are used to de-ice roads and improve winter driving conditions (Ecoplans and Hodgins 2013; Environment Canada 2012). The de-icing of highways and roads in the winter causes increased chloride concentrations at multiple spatial scales (local, regional, and national; Thunqvist 2004; Corsi et al. 2010). Chloride is also known to accumulate in groundwater and release gradually over time (Kaushal et al. 2005), and is linked to increasing conductivity (a measurement related to ion concentration; Morgan II et al. 2007). The Canadian Council of Ministers of the Environment (CCME) has established chloride concentrations that are known to cause acute $\left(640 \mathrm{mg} \mathrm{Cl}^{-} / \mathrm{L}\right)$ and chronic $\left(120 \mathrm{mg} \mathrm{Cl}^{-} / \mathrm{L}\right)$ harm in aquatic ecosystems (CCME 2011). Increased chloride levels can cause physiological disruptions in aquatic organisms resulting from the inability to properly regulate ion exchange (Holland et al. 2011), which ultimately impacts trophic cascades (Hintz et al. 2017) and biodiversity (Castillo et al. 2017; Hintz and Relyea 2019).

\subsubsection{LAND-USE CHANGE}

Land-use change refers to alterations in both land use (the specific human uses of the land) and land cover (the variety and condition of the biological and physical aspects of the land; Meyer and Turner 1996). Generally, patterns of land-use change trend toward converting natural ecosystems into urban, residential, agricultural, or industrial areas that provide benefits to humans (Foley et al. 2005). This is the case in southern Ontario, Canada, where there is a trend towards urban land replacing agricultural land (Hofmann et al. 2005). However, these same land-use categories that benefit humans put a strain on freshwater ecosystems by increasing water demands (Rosegrant et al. 2003), increasing 
the susceptibility to invasions by non-native species (Scott and Helfman 2001), degrading riparian vegetation buffers which filter pollutants and reduce runoff (Osborne and Kovacic 1993), altering hydrologic regimes (Allan 2004), and by decreasing biodiversity (Weijters et al. 2009).

Surrounding land-use type also dictates the chemical and physical composition of aquatic ecosystems (Carpenter et al. 2011). In riverine ecosystems where urban land has replaced agricultural land, salinisation has been observed (Kaushal et al. 2005; Bazinet et al. 2010; Winter et al. 2011b). Nutrient loading from both urban and agricultural lands are well-documented (Carpenter et al. 1998; Soranno et al. 1996), and increased inputs of sediment from agricultural land (Walling 1999) and construction sites have also been noted (Wolman and Schick 1967).

\subsubsection{PHYSICAL ALTERATIONS OF HYDROLOGIC FLOWS}

The hydrology of freshwater ecosystems has been altered with dams, reservoirs, dikes, and canals, for storage, hydroelectric, flood prevention, agricultural, and navigational purposes (Dynesius and Nilsson 1994; Meybeck 2003). Altered water flows harm riverine habitats by modifying channel morphology and in-stream substrates (Poff et al. 1997; Sparks 1995) and harm riparian habitats by causing flooding and erosion upstream, and channel straightening and salinisation downstream (Nilsson and Berggren 2000). Changing the natural flow regimes of rivers can also negatively impact aquatic species who have stages in their life cycle that rely upon specific flow conditions and water levels (Bunn and Arthington 2002). The biodiversity of algae, plants, invertebrates, and fish in freshwater habitats at local, landscape, and regional scales are all ultimately impacted by changing flow regimes (Bunn and Arthington 2002; Rolls et al. 2018). The 
increased connectivity provided by canals is also a cause for concern, as it can facilitate invasion by non-native species between areas that are not historically connected (Rahel 2007). However, dams and dikes have the opposite effect; fragmenting historically connected rivers and streams, and creating barriers for fish passage (Fuller et al. 2015).

\subsubsection{INTRODUCTION OF INVASIVE SPECIES}

There are a number of mechanisms by which invasive species are introduced outside of their natural range, but humans are largely responsible for the homogenisation of freshwater ecosystems (Rahel 2002). For example, urbanisation creates pathways and opportunities for invasion (i.e., canals, boats; Dextrase and Mandrak 2006) and increases the frequency of introductions of non-native species for human use (i.e., aquaculture, recreational and sport fishing, for ornamental purposes, and global commerce; McKinney 2006; Rahel 2007). Climate change-induced warming, alteration to flow regimes, and salinisation also increase the probability of the introduction and permanence of invasive species by making their non-native habitats more suitable for survival (Rahel and Olden 2008).

The introduction of invasive species into ecosystems outside their native biogeographic range is another threat to freshwater biodiversity at a global scale (Bunn and Arthington 2002; Dudgeon et al. 2006). Losses of biodiversity are associated with invasive species outcompeting native species for resources (Moyle and Light 1996; Ricciardi et al. 1998) and with the hybridization of native species to the point of extinction (Miller et al. 1989; Mooney and Cleland 2001). Invasive species also degrade the habitats they invade, making them less suitable for their native counterparts (Wilson and Ricciardi 2009), and have implications for other species in the trophic cascade 
(Ricciardi and MacIsaac 2010). For example, invasions can impact insectivorous fish and invertebrate communities (Flecker and Townsend 1994), and alter nutrient cycles (Schindler et al. 2001), which both result in increased algal biomass.

\subsubsection{CLIMATE CHANGE}

It is well known that climate change has numerous harmful effects on freshwater ecosystems (Carpenter et al. 1992; Kernan et al. 2010; Schindler 1997). Climate warming alters precipitation patterns, which increases the frequency and severity of storms, floods, and droughts (Trenberth 2011). Changes to the hydrologic flows can cause flood-induced channel erosion and drought-induced fragmentation, among other impacts (Palmer et al. 2009). Global warming can also cause increased snowfall in the winter and thus increased spring snowmelt and runoff in high-latitude regions, and decreased precipitation and runoff in in lower-latitude regions (Nijssen et al. 2001).

Climate change also alters the cycle of lake ice freezing and melting (Latifovic and Pouliot 2007) and the frequency of annual lake mixing (Woolway and Merchant 2019), causing changes to biogeochemical cycles and the concentration of dissolved substances, including oxygen (Boehrer and Schultze 2008). Furthermore, water clarity in lakes can be enhanced as more frequent droughts reduce terrestrial runoff, and therefore decrease allochthonous inputs of carbon (Schindler et al. 1996). Increased global temperatures also lowers the solubility of dissolved oxygen in shallow freshwater ecosystems, and can cause deep lakes to become increasingly stratified (Jane et al. 2021); oxygen depletion in fresh water has implications for biodiversity and biogeochemical cycles (Palmer et al. 1997). 


\subsubsection{CUMULATIVE EFFECTS OF MULTIPLE STRESSORS}

Finally, it is important to take note of the cumulative effects caused by the occurrence of multiple stressors in freshwater ecosystems. Cumulative effects are the combined environmental changes that occur as a result of past, present, and potential impacts (Naiman and Turner 2000). However, the cumulative effects and interactions between multiple stressors are not easy to disentangle and quantify (Ormerod et al. 2010). In many cases $(56 \%)$, multiple stressors counteract one another resulting in a reduced or inverse impact on the environment, but synergistic (28\%) and additive (16\%) environmental impacts do not go unnoticed (Jackson et al. 2016). Beyond antagonistic, synergistic, and additive environmental impacts, the cumulative effects of land-use change together with the physical alteration of hydrologic flows, can result in an ecological regime shift from one state of balance between biological, chemical, and physical conditions, to another (Davis et al. 2010). In freshwater ecosystems, these states may range from macrophyte- to phytoplankton-dominated, and from turbid to clear (Davis et al. 2003; Scheffer et al. 1993).

With climate change having an impact on freshwater ecosystems globally, it is equally important to consider the cumulative effects of climate change with other stressors. For example, despite nutrient concentrations high enough to cause high algal biomass, climate change and salinisation have instead forced low algal biomass in Canadian prairie lakes (Sereda et al. 2011). Climate warming in combination with urbanization and increased agricultural land-use is also expected to cause declines in freshwater biodiversity as a result of increased quantities of nutrient-rich runoff from urban land, increased sedimentation rates, and increased water temperatures (MantykaPringle et al. 2014; Piggott et al. 2015). 


\subsection{ALGAE IN LACUSTRINE AND RIVERINE ECOSYSTEMS}

The abundance, biomass, and community composition of algae is shaped by the chemical, biological, and physical characteristics of their environment, over temporal and spatial scales (Wetzel 2001). While periphyton and phytoplankton differ in their growing location (attached versus free-floating) and their primary growth-limiting factors (light versus nutrients; Hansson 1988), they are both found in lacustrine and riverine ecosystems. However, lacustrine phytoplankton dynamics are better understood than riverine phytoplankton, and periphyton in rivers is better studied than periphyton in lakes (Cantonati and Lowe 2014).

Algae require both phosphorus and nitrogen to maintain metabolic activity and sustain growth (Dignum et al. 2005; Wetzel 2001), however phosphorus is most often the limiting nutrient for algal growth in freshwater ecosystems (Hecky and Kilham 1988). Generally, rivers are less likely to be nutrient limited than lakes as nutrient retention and recycling rates are high; however, large rivers may behave similarly to shallow lakes in this regard and can experience nutrient limitation (Reynolds et al. 1994; Wetzel 2001).

When phosphorus concentrations are increased in a phosphorus-limited ecosystem, algal growth increases dramatically and is sustained until phosphorus is limited again (Schindler 1971; Schindler et al. 2008, 1971). Algal growth can also become limited by nitrogen, but certain species of cyanobacteria (i.e., Anabaena) are capable of fixing atmospheric nitrogen, which ultimately increases nitrogen concentrations and makes it available for use by other species (Schindler 1977; Schindler et al. 2008). Therefore, low nitrogen to phosphorus ratios can be problematic in freshwater ecosystems as nitrogenfixing species of cyanobacteria often form nuisance algal blooms that are a detriment to ecosystem and human health (Schindler et al. 2008). 
Biotic interactions (competition and grazing) also impact phytoplankton and periphyton biomass and community composition. The "paradox of the plankton" first described that multiple species of algae are able to coexist and utilize the same resources in an aquatic ecosystem without experiencing competitive exclusion (Hutchinson 1961; Tilman 1977). There are a number of reasons why algae are able to coexist with high biodiversity, including the instability of environmental conditions which prevents competitive exclusion by changing resource availability, symbiotic relationships between algal species, and selective grazing by predators (Wetzel 2001). Algal species also avoid interspecific competition for resources by having species-specific habitats and seasonal succession (Moss 1972), and unique buoyancies, motile capabilities, and optima for light, temperature, and nutrients (Jöhnk et al. 2008).

Algae are the primary producers forming the basis of aquatic food webs, with both phytoplankton and periphyton contributing to whole ecosystem productivity (Vadeboncoeur et al. 2002). The main consumers of phytoplankton are zooplankton and macroinvertebrates (Carpenter et al. 1985), while periphyton are mainly consumed by macroinvertebrates and herbivorous fish (Vadeboncoeur and Power 2017). In lakes, grazing pressure on phytoplankton can be particularly intense and can cause noticeable declines in biomass (Lampert et al. 1986; Vanni and Temte 1990). The intense grazing pressure on algae by zooplankton seen in lacustrine ecosystems is not frequently observed in riverine ecosystems where the physical environment plays a larger role in the formation of algal communities (Reynolds et al. 1994). However, grazing pressure from macroinvertebrates has been noted in riverine ecosystems (Basu and Pick 1997; Biggs et al. 1998b). 
Evidently, lacustrine and riverine ecosystems differ in their physical environments. Water current velocity and water residence time structure algal communities in rivers and streams (Biggs and Close 1989; Cha et al. 2017). The flow regime of rivers creates unique habitats through sedimentation and interactions between the floodplain and main river channel (Poff et al. 1997), impacts nutrient cycling (Houser and Richardson 2010), and creates an upstream to downstream gradient of chemical and biological conditions (Vannote et al. 1980). Riverine algae also do not often experience the same degree of light limitation experienced in lakes as smaller rivers normally allow full light penetration to the bottom of the water column, unless the water is particularly turbid or shaded by tree cover (Allan et al. 2021; Vannote et al. 1980).

Initially, it was unclear if phytoplankton in rivers were distinct from phytoplankton that form in lacustrine environments; however it is now known that rivers are capable of forming a "true" riverine phytoplankton called potamoplankton (Chételat et al. 2006; Köhler 1994; Reynolds and Descy 1996; Reynolds and Glaister 1993). Potamoplankton are distinct from lacustrine phytoplankton because their physical environment is more variable; this variability limits the algal response to the chemical aspects of their environment during the time in which they are exposed (Reynolds 2000). For example, if water flow rates are very high, potamoplankton are not exposed to nutrients for a long enough period of time to enable further growth, whereas during low flows, the prolonged exposure to nutrients facilitates growth (Reynolds 2000).

Algal biomass can be estimated in a number of ways, but chlorophyll-a concentration and ash-free dry mass are two common methods for analysing phytoplankton and periphyton samples (Wetzel and Likens 2000). The characterization of 
algal community composition is done by identifying and enumerating algal cells using various microscopy techniques (Wetzel and Likens 2000). Advances in flow cytometry and imaging technology since the late 1990s have allowed researchers to more quickly quantify algal abundance and enumerate algal cells (Sieracki et al. 1998) which has implications for monitoring algae and zooplankton in fresh water (Detmer et al. 2019; Graham et al. 2018; Hrycik et al. 2019; Tarrant et al. 2009).

\subsection{MONITORING CHANGES IN FRESHWATER ECOSYSTEMS WITH ALGAE}

The long-standing principle stemming from microbiology that "everything is everywhere, but the environment selects" has been used to describe the biogeography of algae (Baas Becking 1934). Algae do not experience the same limitations to dispersal as larger organisms and are generally without barriers that prevent their distribution on a global scale (Fenchel and Finlay 2004). Furthermore, the increasing homogenization of the world's water as a result of globalization (Perrings et al. 2005; Vitousek et al. 1996) facilitates and enhances the already numerous modes of dispersal that algae have (wind, water, animals, and humans; Kristiansen 1996). However, the biological, chemical, and physical characteristics of the surrounding environment structure the algal community in a given location (Wetzel 2001). This is why algae can effectively be used to monitor environmental changes across a variety of ecosystems (McCormick and Cairns 1994) and detect the impacts of human activity early (Schindler 1987).

Environmental changes can be monitored more effectively with lower algal classifications (i.e., genus, species) as they are more sensitive to changes than higher classifications (i.e., biomass, presence-absence; Schindler 1990). While lacustrine and riverine ecosystems vary in their water flow characteristics, the same algal indicators of 
ecosystem status are frequently used (DeNicola and Kelly 2014). However, some differences exist between algal community composition in lakes and rivers, and this should be considered when developing monitoring programs. For example, in rivers and lakes with similar nutrient concentrations, lakes demonstrated higher species richness, while diatom cell lengths in rivers were greater (Kahlert and Gottschalk 2014).

Furthermore, diatom assemblages in rivers are somewhat more spatially structured than those in lakes; however, both lacustrine and riverine diatom communities are still primarily shaped by environmental factors which could justify similar monitoring guidelines between the two ecosystems (Soininen and Weckström 2009).

\subsection{GEOGRAPHY OF THE RIDEAU CANAL}

The Rideau Canal (202 km long) is located in southeastern Ontario, Canada and is composed of two distinct rivers: the Rideau River, which flows from Upper Rideau Lake in Rideau Lakes to the Ottawa River in Ottawa; and the Cataraqui River which flows from Newboro Lake in Rideau Lakes to Lake Ontario in Kingston, Ontario, with a series of natural lakes in the central section. Upper Rideau Lake marks the highest point in the Rideau Canal, approximately $125 \mathrm{~m}$ above sea level. The canal features 47 locks at 24 lock stations, and was constructed in a manner that preserved a large proportion of the natural rivers and lakes (only $9 \%$ of the waterway was excavated during construction; Parks Canada 2006).

The Rideau River watershed has an area of $3830 \mathrm{~km}^{2}$ and is mainly surrounded by forested and wetland-covered land (50\%), agricultural land (30\%), and urban land (12\%; RVCA 2019). The Rideau River tertiary watershed is comprised of 10 quaternary watersheds (Bobs Lake, Lower Rideau Lake - Rideau River, Tay River, Edmonds Dam Rideau River, Irish Creek, Burritts Rapids Dam - Rideau River, Kemptville Creek, 
Stevens Creek - Rideau River, Jock River, Rideau Falls - Rideau River) which all eventually drain into the Rideau River (Figure 2-1). The south-western section of the Rideau River watershed lies on the Canadian Shield (Frontenac Axis; a rock formation composed of Precambrian rock) while the remainder of the watershed sits upon limestone, dolomite, and shale (Davidson 1990; Guillet 1977).

In comparison, the Cataraqui River watershed is much smaller, draining an area of only $910 \mathrm{~km}^{2}$, and is mainly surrounded by forested land $(60 \%)$, some agricultural land (22\%), and only $1 \%$ urban land (CRCA 2008). The Cataraqui River - St. Lawrence River tertiary watershed is comprised of 6 quaternary watersheds (Cataraqui River, Lake of the Isles - St. Lawrence River, Gananoque River, Wiltse Creek, Jones Creek, Butlers Creek St. Lawrence River), of which only the Cataraqui River quaternary watershed drains into the Cataraqui River (Figure 2-1). Most of the Cataraqui River watershed sits on top of the Canadian Shield, with only the southern-most area lying upon limestone and clay (Guillet 1977; CRCA 2011). 


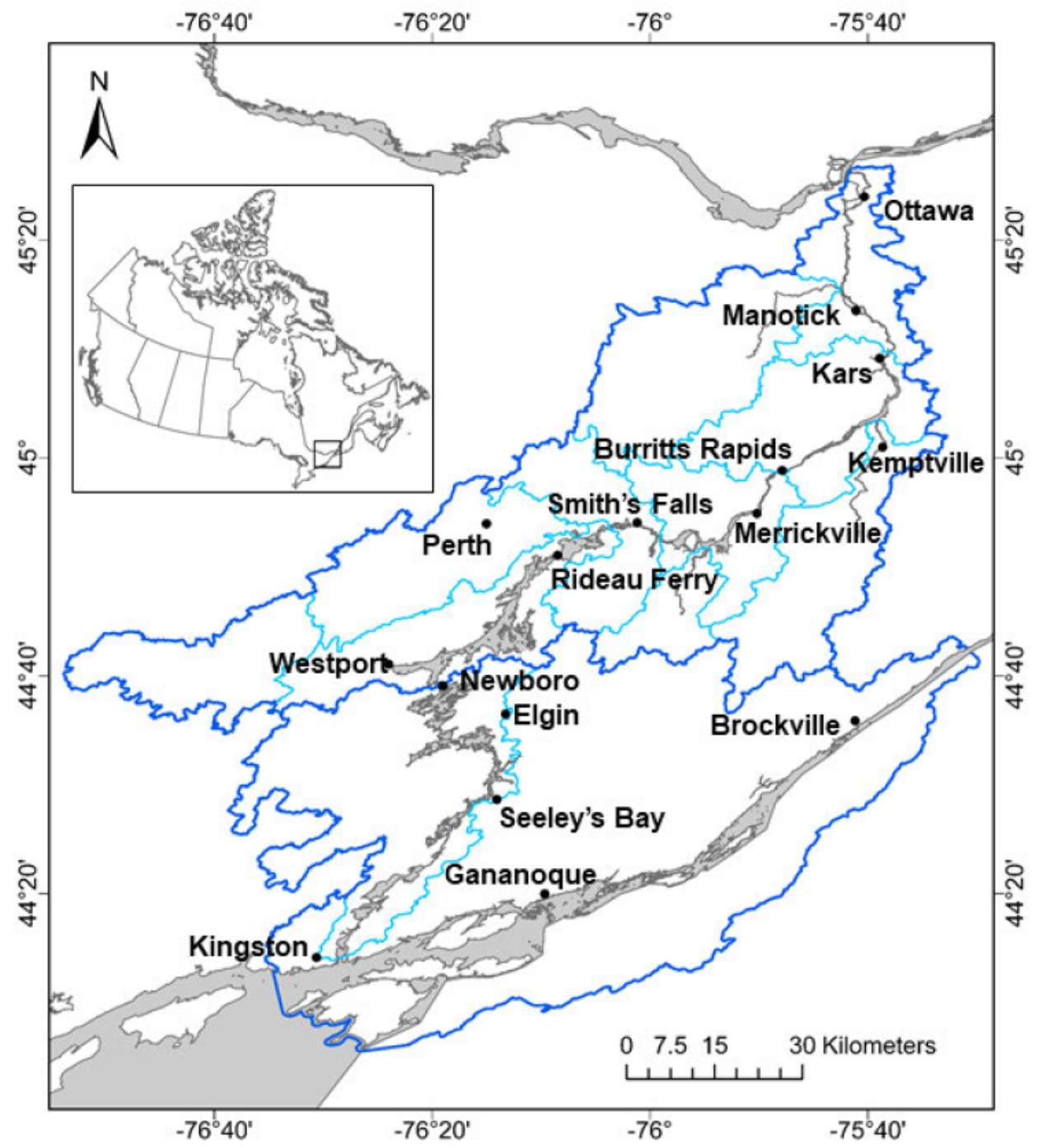

Figure 2-1. Map of the Rideau Canal in Ontario, Canada with the Rideau River (north) and the Cataraqui River - St. Lawrence River (south) tertiary watersheds outlined in dark blue. The quaternary watersheds that drain into the Rideau River and Cataraqui River are outlined in light blue. Map created in ArcGIS Pro 2.1.0 using geospatial data acquired from Natural Earth (2018), Natural Resources Canada (2017), and Ontario Ministry of Natural Resources and Forestry (OMNRF; 2020).

In the late 1700s, Europeans began settling near the rivers in the Cataraqui and Rideau watersheds to establish water-powered mills for timber, grain, and textiles (Watson 2007). The construction of the Rideau Canal began in 1826 as a preventative, military measure taken by the British should the United States become an enemy and the need to protect our vulnerable southern border arise. The Rideau Canal is a slackwater 
canal that uses dams and locks to create bodies of water (impoundments or reservoirs) that maintain water levels in the canal. Slackwater canals were not common in the early $19^{\text {th }}$ century as they were perceived to be more difficult to build and maintain due to the high proportion of natural river that remains after construction, and because of concerns raised over fluctuating water levels in the impoundments (Parks Canada 2006). With the construction of the canal, the Cataraqui River was transformed into a larger, straighter river, flooding many wetlands, and creating several man-made lakes (Watson 2006). The man-made lakes include Colonel By Lake, the River Styx, Dog Lake, Cranberry Lake, Little Cranberry Lake, Whitefish Lake, and Mosquito Lake.

After the Rideau Canal was completed in 1832, it primarily facilitated commercial transportation between the Great Lakes and Montreal, as this route was safer than the rough waters of the St. Lawrence River (Parks Canada 2021). Since the 1960s, the waterway has mainly been used for recreational and touristic purposes (Parks Canada 2006). The Rideau Canal is a National Historic Site of Canada and was designated a Canadian Heritage River in 2000 and a UNESCO World Heritage Site in 2007. In recent years, stakeholders, residents, and a local activist group (Three Lakes Water Quality Group) have actively collaborated with other stakeholders and government departments to address the water quality issues the Rideau Canal experiences, especially with respect to algal blooms (Figure 2-2; Mistry et al. 2021). 


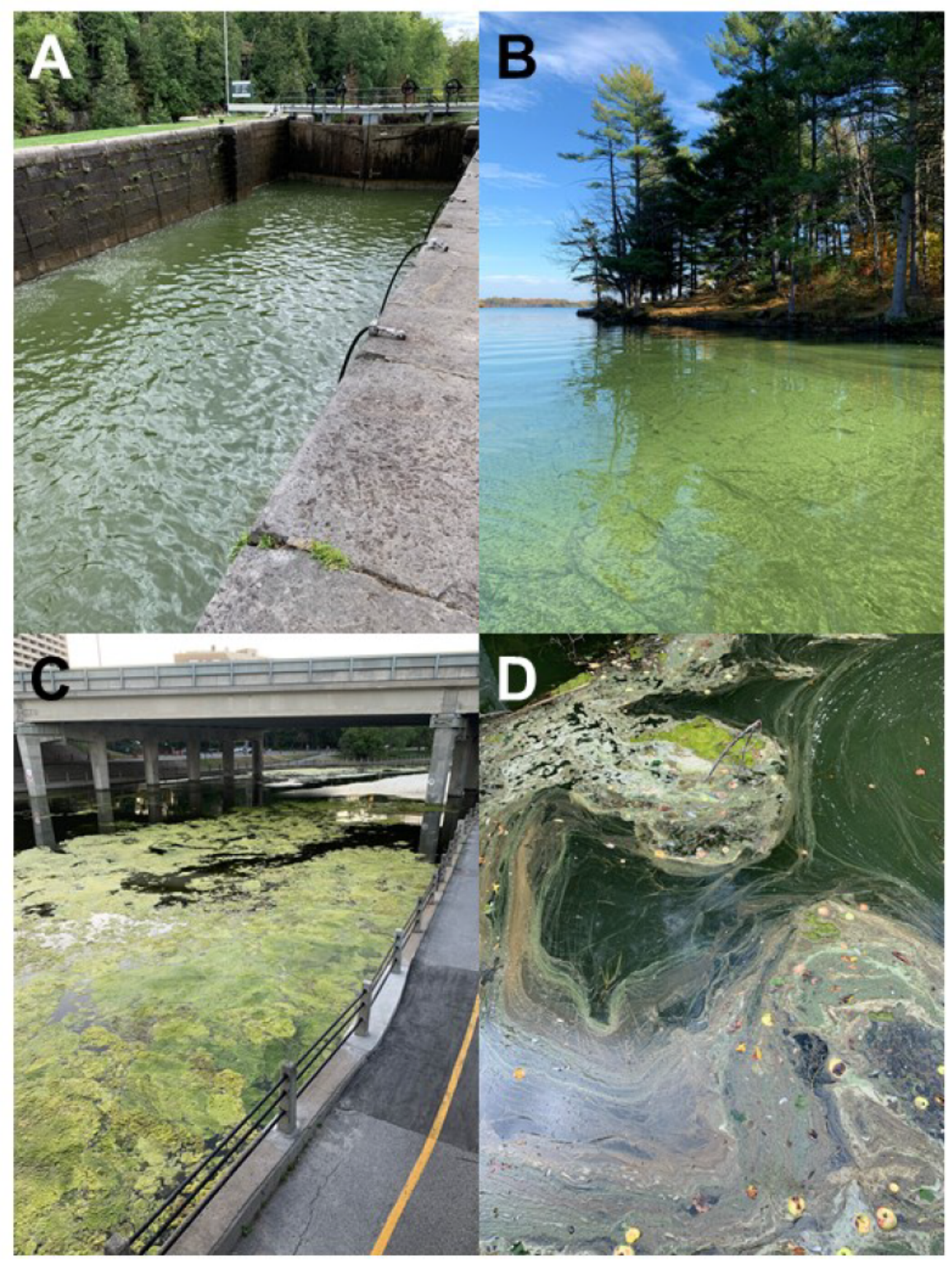

Figure 2-2. Examples of harmful algal blooms in the Rideau Canal. A) Kingston Mills lock station B) Dog Lake C) downtown Ottawa D) Kingston Mills lock station. 


\subsection{DRIVERS OF ALGAL BIOMASS AND COMMUNITY COMPOSITION}

IN THE RIDEAU CANAL

\subsubsection{NUTRIENT LOADING}

Since diatoms are sensitive to changes in their environment, paleolimnological analyses of diatom community composition can be used to infer chemical, biological, and physical changes to the environment over long time scales (Smol 2010). This type of analysis has been used to study a number of lakes along the Rideau Canal, including Upper Rideau Lake (Christie and Smol 1996), Lake Opinicon (Karst and Smol 2000), Colonel By Lake (Sonnenburg et al. 2009), Lower Rideau Lake, Otter Lake, Big Rideau Lake, and Indian Lake (Forrest et al. 2003). Generally, these studies surmise that the Rideau and Cataraqui rivers have always been somewhat productive, and that the construction of the Rideau Canal and increased forestry and agricultural activity contributed to the meso- and eutrophic conditions of the lakes today. Furthermore, both the Cataraqui Region Conservation Authority (CRCA) and the Rideau Valley Conservation Authority (RVCA) report poor and fair water quality at many sites within their watersheds (RVCA 2012, 2014; CRCA 2013, 2018).

In the Rideau River, phytoplankton biomass was found to be related to total phosphorus (Basu and Pick 1997, 1995) and even more so with soluble reactive phosphorus (Hamilton et al. 2011). It is also possible that nitrogen explains some of the variation in phytoplankton biomass in the Rideau River (Yang et al. 1997). However, the relationships between phytoplankton biomass and nutrients are not always evident, and other physical and biological characteristics of the river may be responsible for the dissociation between phytoplankton biomass and nutrient concentrations (Hamilton et al. 2012; Vidal et al. 2004). Periphyton biomass has also previously shown a positive 
relationship with total phosphorus concentration in the Rideau, Jock, and Ottawa rivers (Chételat et al. 2000), and in another study of the Rideau and 12 other rivers in the region where total nitrogen also explained some of the variation in periphyton biomass (Chételat et al. 1999).

\subsubsection{SALINISATION}

Much of the road salt applied as a de-icer in the winter ends up in aquatic ecosystems from runoff (Bubeck et al. 1971; Crowther and Hynes 1977), but salts are also found in urban snow (Oliver et al. 1974) and can leach into groundwater (Williams et al. 1999). Inputs of chloride from road salts results in elevated chloride concentrations both during the winter and spring when road salts are applied and when snow melts (Corsi et al. 2010; Kaushal et al. 2005; Kerr 2017), and year-round as road salts are stored in soil and groundwater and released gradually into aquatic ecosystems over time (Corsi et al. 2015). Mean chloride concentrations in the Rideau River ranged from 11.4 to $14.7 \mathrm{mg} / \mathrm{L}$ in 1998-2000, with the maximum concentration only reaching $35 \mathrm{mg} / \mathrm{L}$ in 1999 (Poulin 2001), which is well below both the acute $(640 \mathrm{mg} / \mathrm{L})$ and chronic $(120$ $\mathrm{mg} / \mathrm{L}$ ) chloride concentrations for the protection of aquatic life in Canada (CCME 2011). However, the Ottawa Riverkeeper (2020) has noted that chloride concentrations in two creeks in Ottawa (Graham Creek and Pinecrest Creek) have been consistently higher than $120 \mathrm{mg} / \mathrm{L}$ since 1998 , and they attribute these concentrations to overuse of road salts in the winter. In the 2019-2020 winter season, the City of Ottawa used over 167,000 tonnes of salt and sand to de-ice 15,000 km of roads and sidewalks (City of Ottawa 2021).

While the impacts of chloride on algae in the Rideau Canal have not been studied, chloride does cause a variety of negative impacts on aquatic ecosystems (Evans and Frick 
2001). For example, at chloride concentrations below $500 \mathrm{mg} / \mathrm{L}$, zooplankton biomass increases while phytoplankton biomass decreases as a result of increased grazing pressure; above $500 \mathrm{mg} / \mathrm{L}$, the opposite relationship is seen (Moffett et al. 2020; Van Meter et al. 2011). It is only at very high chloride concentrations (greater than 2400 $\mathrm{mg} / \mathrm{L}$ ) in laboratory tests that freshwater phytoplankton growth inhibition has been recorded (Mohammed and Shafea 1992; Patrick et al. 1968; Setter et al. 1982).

\subsubsection{WATER FLOW RATES}

Since algal abundance and community composition is impacted by water flow rate (Reynolds 2000), it is likely to vary along the length of a waterway depending on the physical environment. Most often, water flow rates and residence times are inversely and directly associated, respectively, with phytoplankton biomass and cyanobacterial dominance (Feipeng et al. 2013; Köhler 1993; Lohman et al. 1992; Moss and Balls 1989; Salmaso and Braioni 2008; Zhang et al. 2015). In the Rideau River, phytoplankton biomass is higher in lentic headwater lakes, which have longer residence times, than it is just after it enters the higher flow riverine environment (Basu and Pick 1997, 1995; Yang et al. 1997). Furthermore downstream reaches of the Rideau River with longer residence times than fast flowing reaches have increased phytoplankton biomass composed mainly of larger algae $(>64 \mu \mathrm{m})$ that require longer residence times to develop (Yang et al. 1997). It is also important to note that water discharge rates in the Rideau River are controlled to manage water levels in the Rideau Canal. Despite this, the anthropogenically-regulated discharge rates continue to drive phytoplankton standing stock in the Rideau Canal over longer sampling periods (3 years), regardless of seasonal changes in rainfall (Hamilton et al. 2012, 2011). 
For periphyton, the "subsidy-stress" relationship hypothesized by Biggs et al. (1998a) plays an important role in the continued formation (subsidy) or dismantling (stress) of a periphyton matrix. The hypothesis postulates that the structure of the periphyton matrix (dense, short-filamentous, or long-filamentous) will respond to increased water velocities by either monotonically increasing, unimodally increasing then decreasing, or by monotonically decreasing it's biomass, respectively (Biggs et al. 1998a). For example, periphyton biomass accumulates most effectively in rivers with lower current velocities $(<0.3 \mathrm{~m} / \mathrm{s})$, while higher current velocities $(>0.7 \mathrm{~m} / \mathrm{s})$ cause accumulated periphyton to be sloughed off, thus decreasing overall biomass (Biggs and Stokseth 1996). However, in a study of rivers in southern Ontario and western Quebec with water current velocities ranging between 0.1 and $1.7 \mathrm{~m} / \mathrm{s}$, neither periphyton biomass nor community composition were associated with water current velocity (Chételat et al. 1999). This lack of relationship with flow rate was attributed to the broad scale of the study across rivers with highly variable nutrient concentrations and periphyton community compositions (Chételat et al. 1999).

\subsubsection{INVASIVE SPECIES}

The impacts of invasive species on algal biomass and community are largely dependent on the introduced species and their position in the trophic cascade (Gallardo et al. 2016). The Rideau Canal is home to a number of aquatic invasive species, including Dreissena polymorpha (zebra mussels), Orconectes rusticus (rusty crayfish), Bythotrephes longimanus (spiny water flea) and Neogobius melanostomus (round goby), and Myriophyllum spicatum (Eurasian watermilfoil) and Hydrocharis morsus-ranae (European frog-bit; Poulin 2001; CRCA 2017). 
Zebra mussels are presumed to have been introduced into the Rideau River somewhere between Mooney's Bay in Ottawa and the Rideau River proper in Kars, Ontario in the fall of 1990 by a large boat which had travelled through Lake Ontario and Lake Erie (Martel 1995). Populations in the Rideau River expanded rapidly between 1990 and 1995, with mean zebra mussel density surpassing 300000 mussels $/ \mathrm{m}^{2}$ in some downstream reaches (Martel and Madill 2018). It was in 1995 that zebra mussels were first noted in the Cataraqui River (Benson 2014).

Zebra mussels are aggressive filter feeders which outcompete native mussels for their phytoplankton food source (Ricciardi et al. 1998; Strayer 1999), and are a biofouling organism that effectively smother and starve native mussels who do not have anti-fouling evolutionary strategies (Haag et al. 1993; Ricciardi et al. 1996). The high ingestion rate of phytoplankton by zebra mussels also leads to increased water clarity (Caraco et al. 1997), which can increase the biomass of benthic periphyton which is normally light-limited (Lowe and Pillsbury 1995). Basu and Pick (1997), Vidal et al. (2004), and Hamilton et al. (2012) demonstrated a clear negative relationship between phytoplankton biomass and the concentration of zebra mussel veligers in the Rideau River. Zebra mussels can also alter community composition of both phytoplankton (Bastviken et al. 1998) and benthic periphyton (Pillsbury et al. 2002) to favour taxa that are more resistant to ingestion.

Rusty crayfish are native to the Ohio River Basin in the United States, and were first introduced into Ontario in the early 1960s, though the exact year these crayfish were introduced to the Rideau Canal is not known (Crocker and Barr 1968). This invasive species outcompetes native crayfish (Garvey et al. 1994), and decreases the biodiversity 
of both native crayfish and macroinvertebrate species (Reid and Nocera 2015; Wilson et al. 2004). Rusty crayfish are a detriment to multiple trophic levels in the ecosystems they invade (Charlebois and Lamberti 1996). Rusty crayfish directly impact macroinvertebrate communities by consuming them, and indirectly impact macroinvertebrates by voraciously consuming their food sources and degrading their habitats (Charlebois and Lamberti 1996; Lodge and Lorman 1987; Wilson et al. 2004). The reduction in macroinvertebrate abundance and diversity results in increased biomass and primary productivity of periphyton, possibly due to the fact that herbivorous macroinvertebrates are greater consumers of periphyton than rusty crayfish (Bobeldyk and Lamberti 2008). The spiny water flea and round goby have only been reported in the Rideau Canal recently; the spiny water flea in 2015 and 2018, and the round goby in 2015 and 2019 (EDDMapS 2021). Spiny water flea may increase phytoplankton biomass in the Rideau Canal because it mainly feeds on grazing zooplankton which removes grazing pressure on phytoplankton (Walsh et al. 2016). Furthermore, spiny water flea thrives in non-native habits as native, small planktivorous fish are unable to consume it because of it's long caudal spine (Barnhisel and Harvey 1995; Compton and Kerfoot 2004). If populations become more established in the Rideau Canal, the round goby may also increase both periphyton and phytoplankton biomass, as macroinvertebrates and dreissenid mussels, specifically, are heavily preyed upon by round gobies (Barton et al. 2005; Lederer et al. 2006; Walsh et al. 2007).

One common characteristic of invasive macrophytes is their ability to outcompete native macrophytes, causing massive reductions in biodiversity (Fleming and Dibble 2015). The Rideau Canal was exposed to a number of invasive macrophytes prior to the 
1970s, including European frog-bit and Eurasian milfoil. European frog-bit was first documented in the Rideau Canal in 1939 via ponds near Dow's Lake in Ottawa, where it was first introduced as an ornamental plant in 1932 (Catling et al. 2003), and Eurasian milfoil was introduced into the Rideau Canal in the 1960s (Aiken et al. 1979).

The main mechanism by which Eurasian milfoil outcompetes other macrophytes is through shading (Madsen et al. 1991). Eurasian milfoil can also diminish the growth of algae via allelopathy, whereby the macrophyte emits allelopathic polyphenols which target and inhibit the growth of cyanobacteria (Gross et al. 1995; Nakai et al. 2000). European frog-bit can increase benthic macroinvertebrate biodiversity and abundance (Zhu et al. 2015); however, the increased shading caused by floating mats of European frog-bit could negatively impact light-limited benthic periphyton production (Quinn et al. 1997). Furthermore, thick floating mats of European frog-bit can also dramatically reduce dissolved oxygen concentrations (Zhu et al. 2008), which can further strengthen their dominance over submerged macrophytes and algae, and give way for a regime shift towards a floating-macrophyte dominant ecosystem (Scheffer et al. 2003).

\subsubsection{CLIMATE CHANGE}

The increasing prevalence of harmful algal blooms in response to long-term climate changes has already been noted in Ontario (Winter et al. 2011a). In the region surrounding Ottawa, climate change is expected to increase temperatures in all seasons, increase the number of freeze-thaw cycles occurring in the winter, reduce winter snowfall, and increase the frequency of summer droughts and periods of high intensity rainfall during other seasons (Braschi et al. 2020). Increased air temperatures will lead to increased water temperatures, which can increase nutrient concentrations and result in 
more frequent and more toxic cyanobacterial blooms (Gilbert 1996; Hallegraeff 1993). Increased water temperature is also a key driver of cyanobacterial production in mesotrophic lakes, and Microcystis, a taxon of cyanobacteria known to produce the potentially lethal toxin microcystin, are especially reactive to temperature changes (Rigosi et al. 2014). Furthermore, climate warming can also increase proportions of cyanobacteria in phytoplankton communities, as certain taxa of cyanobacteria have physiological traits that enhance their survival (Adrian et al. 1995). These evolutionary characteristics, including buoyancy regulation, ability to store phosphorus, their development of akinetes to support resting-cell life stages, and their ability to fix atmospheric nitrogen, can all increase their success in response to the impacts of climate change (Carey et al. 2012).

Reduced ice-cover as a result of increased-freeze thaw cycles in the winter and warming spring temperatures, can also increase the intensity of spring diatom blooms in lakes that do not experience phosphorus limitation (Huber et al. 2008). Less precipitation during the summer months causing droughts can also increase chemical composition of fresh water, resulting in increased salinity and nutrient loads, and increase water residence times, which are ideal conditions for the formation of harmful algal blooms (Mosley 2015). In contrast, high intensity rainfall during fall, winter, and spring can greatly increase surface runoff causing a surge of nutrients, and are followed by periods of lower water flushing rates which can also encourage harmful algal blooms (Moss et al. 2011; Paerl et al. 2016). 


\section{WATER CHEMISTRY AND PERIPHYTON BIOMASS IN THE RIDEAU RIVER: HAVE CONCENTRATIONS CHANGED AFTER 24 YEARS?}

Lindsay L. Trottier ${ }^{1}$, John Chételat $^{2}$, Chantal Vis ${ }^{3}$, Paul B. Hamilton ${ }^{4}$, Frances R. Pick ${ }^{5}$, and Jesse C. Vermaire ${ }^{1,6}$

${ }^{1}$ Department of Geography and Environmental Studies, Carleton University, Ottawa, Ontario, Canada, K1S 5B6

${ }^{2}$ Environment and Climate Change Canada, National Wildlife Research Centre, Ottawa, Ontario, Canada, K1A 0H3

${ }^{3}$ Parks Canada, Protected Areas Establishment and Conservation Directorate, Parks Canada, Gatineau, Quebec, Canada, J8X 0B3

${ }^{4}$ Canadian Museum of Nature, Natural Heritage Campus, Gatineau, Québec, Canada, J9J $3 \mathrm{~N} 7$

${ }^{5}$ Department of Biology, University of Ottawa, Ottawa, Ontario, Canada, K1N 6N5

${ }^{6}$ Institute for Environmental and Interdisciplinary Sciences, Carleton University, Ottawa, Ontario, Canada, K1S 5B6

This chapter will be submitted to the Canadian Journal of Fisheries and Aquatic Sciences. 


\subsection{INTRODUCTION}

Globally, riverine environments are heavily impacted by human activities including changes in water quantity and flow rates, invasive species, land-use change, excessive nutrients, pollution, and climate change (e.g., Reid et al. 2019). Periphyton biomass is in part related to the biological, chemical, and physical properties of a river (e.g., Larned 2010), and is also an important primary producer supporting riverine ecosystems and providing benthic habitat for other organisms (e.g., Vadeboncoeur and Power 2017). Therefore, changes in periphyton biomass can be a key indicator of how human activities are altering riverine ecosystems (Biggs and Close 1989; Hill et al. 2000; Slavik et al. 2004).

Rivers are influenced by surrounding land-use patterns that can alter the biological, physical, and chemical properties of the system (O'Brien and Wehr 2010). For example, at over 200 long-term monitoring sites across Canada, agricultural land-use has been consistently associated with increased levels of nitrogen and phosphorus compared to forested landscapes (Chambers et al. 2012). When agricultural land is converted to urban land, declines in total phosphorus (TP) may be expected as non-point sources of phosphorus from fertilizers are reduced (Carpenter et al. 1998); however, this pattern is not uniform across all study sites and may depend on the type of agricultural land-use before conversion (Raney and Eimers 2014). Further, rivers globally have shown declines in inputs of phosphorus and nitrogen as a result of improved wastewater treatment practices (Schindler 2012), and the impacts of such reductions have wide-ranging ecological consequences in freshwater ecosystems (e.g., Ibáñez and Peñuelas 2019).

The Rideau River is one of two rivers that comprises the Rideau Canal system which extends from the city of Kingston to the city of Ottawa in eastern Ontario, Canada. 
Construction of the Rideau Canal began in the early-1800s with the intention of being a military and commercial route (Charron et al. 1982). Because of its historical significance, the Rideau Canal is designated as a Canadian National Historic Site, a Canadian Heritage River and a UNESCO World Heritage Site (UNESCO 2007; Canadian Heritage Rivers System 2021; Parks Canada 2021). Although the Rideau Canal no longer serves its intended industrial, military, and commercial transportation use, it is an important economic driver of natural capital in the region, attracting more than a million visitors a year for recreation and tourism activities that rely on good water quality and a healthy ecosystem (Butler 1980).

The Rideau River has experienced a series of environmental changes over the last few decades, including land-use changes associated with urban sprawl around the city of Ottawa, climate change, and the introduction of invasive species, including the invasion of zebra mussels (Dreissena polymorpha) in the fall of 1990 (Martel 1995; Martel and Madill 2018; Vidal et al. 2004). However, paleolimnological research has shown that lacustrine ecosystems located within Rideau Canal waterway have been resilient in the face of this environmental change; with the invasion of zebra mussels and nutrient enrichment having little impact on diatom assemblages over the last few decades (Karst and Smol 2000).

Chételat et al. (2000) examined periphyton biomass collected at seven shallow riffle zones, where periphyton growth is not limited by light availability, in 1995 in the mid-section of the Rideau River to examine how periphyton biomass changed with water chemistry. The objective of this study was to revisit these sites to quantify how 
periphyton biomass in the Rideau River has changed, if at all, since 1995 in response to changing environmental conditions over the last 24 years.

\subsection{STUDY SITE}

The Rideau River runs for $110 \mathrm{~km}$ from Upper Rideau Lake to the Ottawa River and drains almost $3900 \mathrm{~km}^{2}$ of land. As of 2014, approximately $45 \%$ of the land in the Lower Rideau sub-watershed was forested or wetland areas, $35 \%$ was agricultural or rural land, and 20\% was urban or residential (RVCA 2019). Land-use change from agricultural to urban/suburban land between 2000-2015 has occurred along the Rideau River as the suburban area around the City of Ottawa has expanded, with the population increasing from approximately 720,000 in 1996 to over one million today (Figure 3-1; OMNRF 2019; Statistics Canada 1996; 2017). Within the study area, upstream land use is primarily forest, wetland, agricultural, and rural land use, with midstream land use being a combination of agricultural, rural, and urban land, and downstream land use becoming increasingly urban as the river approaches the City of Ottawa. 


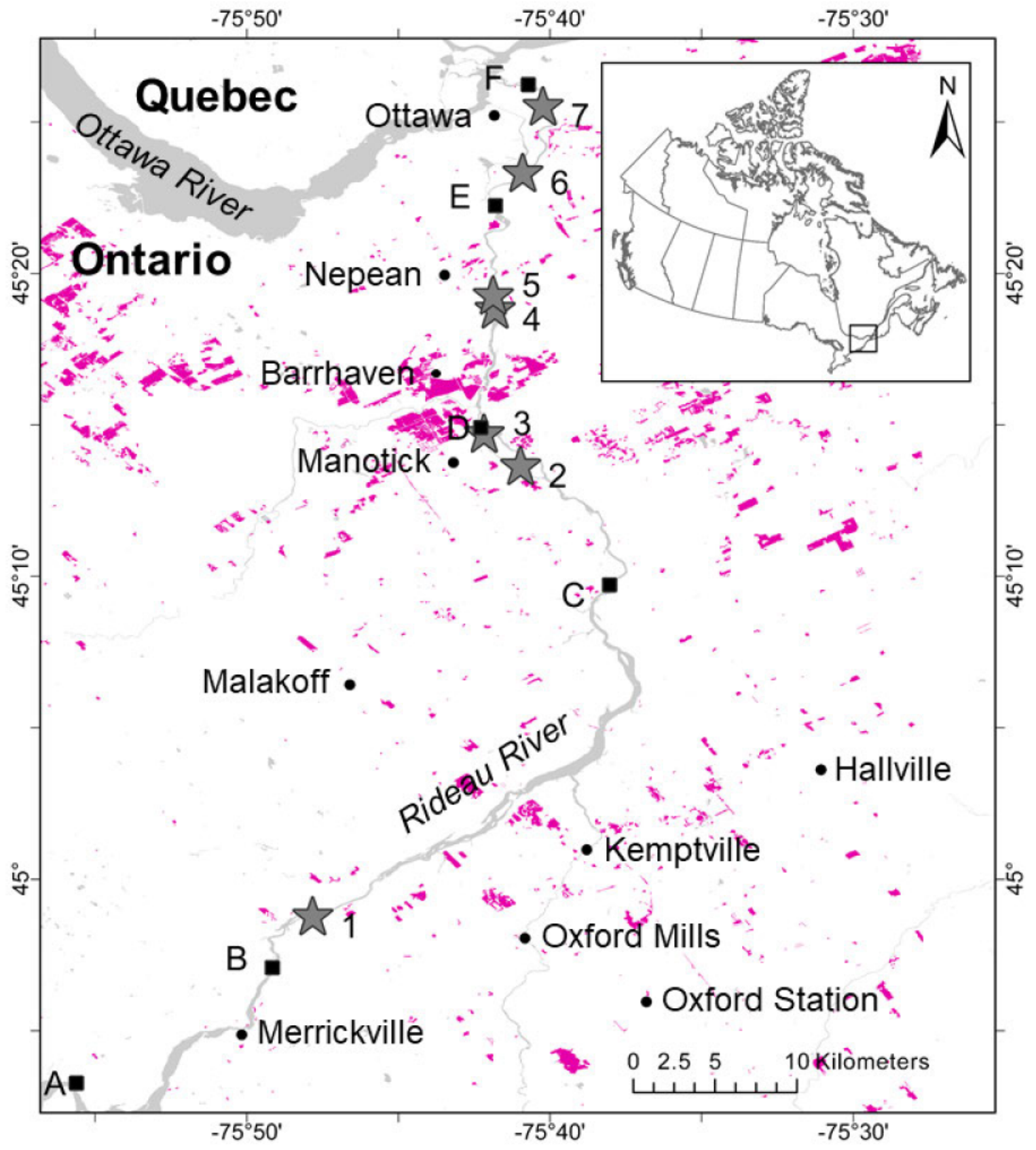

Figure 3-1. Map showing the seven sample sites (stars, 1-7), the six Provincial Water Quality Monitoring Network stations (squares, A-F), and anthropogenic land-use change from 2000 to 2015 (pink) along the Rideau River in Ontario, Canada. Map created in ArcGIS Pro 2.1.0 using geospatial data acquired from Natural Earth (2018), Natural Resources Canada (2017), and Ontario Ministry of Natural Resources and Forestry (OMNRF; 2019). 


\subsection{METHODOLOGY}

Six water quality monitoring stations from the Ontario Provincial (Stream) Water Quality Monitoring Network (PWQMN; OMECC 2018) that best cover the stretch of the river where Chételat et al. (2000) sampled were selected to examine trends in water quality indicators between 2000-2018: 18003302602, 18003303502, 18003302902, 18003303702,18003303102 , and 18003303402 , which are herein referred to as stations A, B, C, D, E, and F, respectively. Data from these PWQMN stations were analysed for temporal trends in total phosphorus (TP), chloride, and total nitrogen (TN) concentrations between 2000 and 2018. Although some PWQMN data stretching back to the 1960s exists for some regions of the province, samples were not collected consistently in this study region until the year 2000. Data collection through the PWQMN between 2000 and 2018 was variable, but most stations were sampled monthly between April and November of each year.

To assess changes in periphyton biomass in the Rideau River, seven sites were selected to match the seven sites sampled in 1995 (Chételat et al. 2000). The sites were located along a $66 \mathrm{~km}$ stretch of the Rideau River (Figure 3-1). Efforts were made to sample near the original locations sampled in 1995 by Chételat et al. (2000), but some of the exact locations sampled in 1995 were no longer publicly accessible via the shore in 2019 due to development in the area, so samples were collected from the nearest point to the previously sampled locations. Summer field sampling followed closely the methods of Chételat et al. (2000). Briefly, eight fist-sized rocks were collected from transects in riffle zones perpendicular to the shore at each of the seven periphyton sites on June 4 and August 2, 2019. The water depth (m) of each rock was measured before being collected, and mean water current velocity $(\mathrm{m} / \mathrm{s})$ was measured at 0.4 times the depth of the rock 
using a Global FP111 Flow Probe Current Meter. A YSI ProPlus Multiparameter Instrument was used to measure conductivity $(\mu \mathrm{S} / \mathrm{cm})$, water temperature, dissolved oxygen, and $\mathrm{pH}$ at three locations at each site. Water samples were also collected at each site for nutrient analyses (TP and total Kjeldahl nitrogen; TKN) at the City of Ottawa Environmental Services Department Water Chemistry Laboratory, the same laboratory where water samples were analysed in Chételat et al. (2000). The methods used to analyse water samples were confirmed to be the same as in 1995 (COESD 2018). All rock and water samples were stored in the dark at $4^{\circ} \mathrm{C}$ until processed. Water samples and physical and chemical parameters of the sampling sites were also collected on three other sampling dates (June 23, July 28, and August 22, 2019) at the upstream edge of each transect to avoid disturbance of the sediment during water sample collection.

In the laboratory, each rock was scrubbed with a nylon brush to remove all periphyton from their surface with a known volume of deionized water. This mixture was homogenized in a blender on high for 30 seconds and used to calculate periphyton biomass per unit area of the rock. The surface area of each rock was estimated by weighing the aluminum foil required to cover the surface of the rock in a single layer. The mass of the aluminum foil was used in a weight-to-area function derived from a linear regression which estimates surface area of the rock based off the mass of aluminum foil ( $\mathrm{y}=0.0025 \mathrm{x}+0.030, \mathrm{r}^{2}=0.99, \mathrm{p}<0.001$; Dudley et al. 2001). Periphyton biomass was quantified in two ways, chlorophyll-a $\left(\mathrm{mg} / \mathrm{m}^{2}\right)$, and ash-free dry mass $\left(\mathrm{g} / \mathrm{m}^{2}\right)$. Both measures of periphyton biomass are presented per unit area of each rock, with the assumption used in Chételat et al. (2000), that periphyton growth only takes place on $60 \%$ of the surface of the rock. 
Chlorophyll-a was measured by filtering 10 to $50 \mathrm{~mL}$ of the periphyton homogenate through Whatman grade 934-AH glass fibre filters using a vacuum filtration system. The filters were wrapped in aluminum foil and frozen until chlorophyll extraction. In a dark room, chlorophyll-a was extracted from each filter in test tubes using $15 \mathrm{~mL}$ of $95 \%$ ethanol heated in a water bath to $79^{\circ} \mathrm{C}$ for 5 minutes (ISO 1992). Test tubes were placed on a rack, wrapped in aluminum foil, and stored in a refrigerator overnight at $4{ }^{\circ} \mathrm{C}$. Approximately $5 \mathrm{~mL}$ of this chlorophyll-a extract solution was filtered through a $0.45 \mu \mathrm{m}$ filter into a glass cuvette $(1 \mathrm{~cm}$ path length) and analysed in a UV-VIS spectrophotometer (Shimadzu UV-1280) at 665 and $750 \mathrm{~nm}$ wavelengths. The absorbance readings of each sample were recorded at each wavelength before subtracting the absorbance at $750 \mathrm{~nm}$ from the absorbance at $665 \mathrm{~nm}$ to correct the chlorophyll-a reading for turbidity. The concentration of chlorophyll-a was standardized according to the volume of deionized water used in the periphyton homogenate, and for the volume of homogenate filtered, per unit area of rock $\left(\mathrm{mg} / \mathrm{m}^{2}\right)$.

In 1995, chlorophyll-a was extracted by Chételat et al. (2000) using a dimethyl sulfoxide (DMSO)-acetone solvent, as described in Burnison (1980) and Jeffrey and Humphrey (1975). In 2019, 95\% ethanol was used to extract chlorophyll-a as the extraction method is simple and safer than that of DMSO-acetone, and the difference in the efficiency of chlorophyll-a extraction between methods is negligible (Sartory and Grobbelaar 1984; Webb et al. 1992). The main difference between the chlorophyll-a analysis method used in this study and the method used by Chételat et al. (2000), is in the equation used to estimate chlorophyll-a from the absorbance readings. The trichromatic equation described by Jefferey and Humphrey (1975; chlorophyll-a $=11.85 \mathrm{E}_{664}-$ 
15.4 $\left.\mathrm{E}_{647}-0.08 \mathrm{E}_{630}\right)$ was used by Chételat et al. (2000), whereas a monochromatic equation is described by Lorenzen (1967) and Wintermans and De Mots (1965;

chlorophyll-a $=29.5 \mathrm{E}_{665}$ ) was used in this study. To account for any discrepancy caused by the use of different spectrophotometric equations, a correction factor was calculated by measuring chlorophyll-a in six samples using both the trichromatic and monochromatic equations described $\left(y=0.3832 x-0.0045, r^{2}=0.998, n=6\right.$; Figure 32). This correction factor ( 0.38$)$ was multiplied by the 2019 concentrations of chlorophyll-a calculated using the monochromatic equation above.

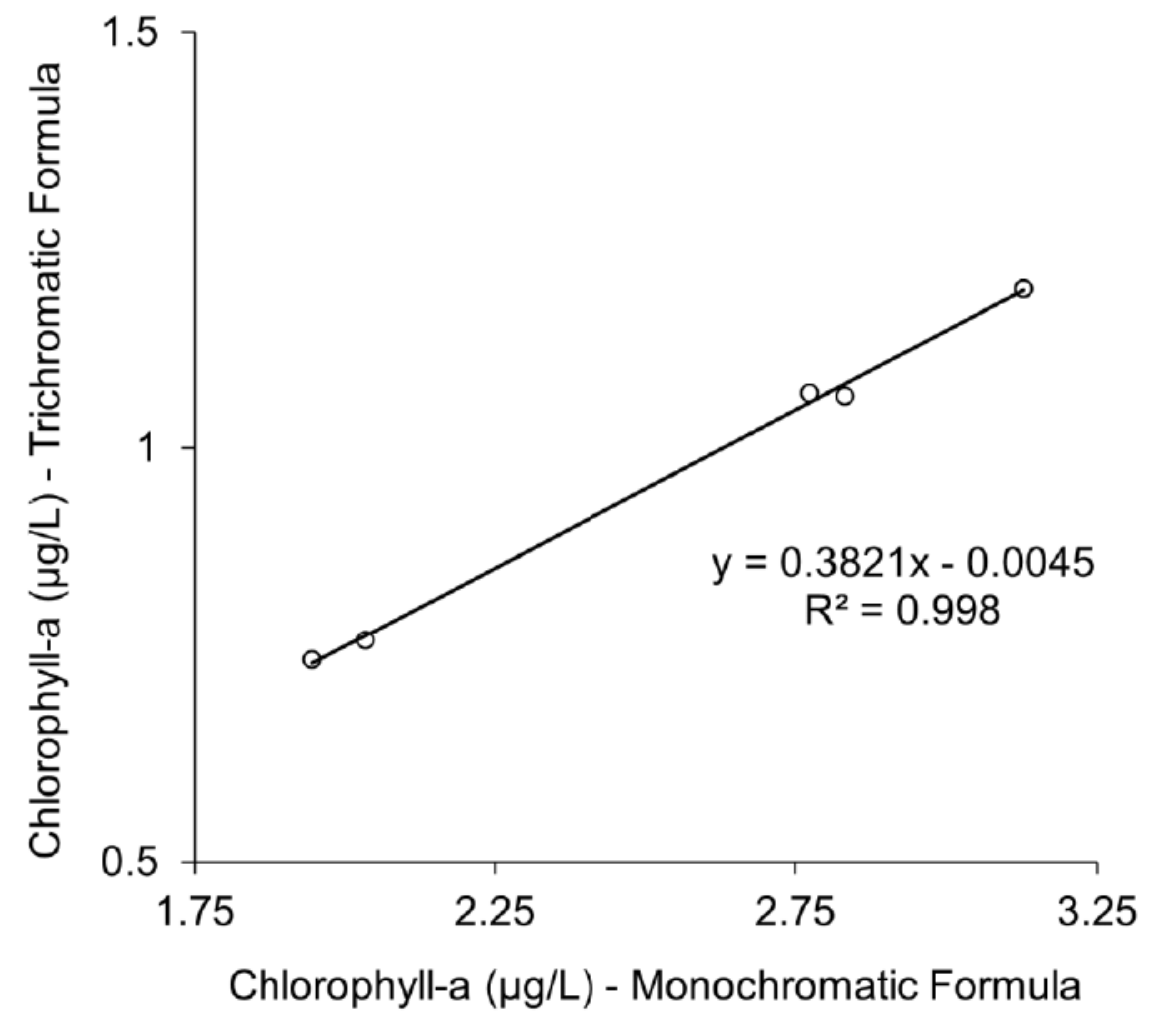

Figure 3-2. The relationship between chlorophyll-a concentration calculated with a trichromatic equation (chlorophyll-a $=11.85 \mathrm{E}_{664}-1.54 \mathrm{E}_{647}-0.08 \mathrm{E}_{630}$; Jefferey and Humphrey 1975) and with a monochromatic equation (chlorophyll-a $=29.5 \mathrm{E} 665$; Lorenzen 1967; Wintermans and De Mots 1965). 
Ash-free dry mass (AFDM) was determined by filtering 10 to $50 \mathrm{~mL}$ of the periphyton homogenate through pre-ashed Whatman grade 934-AH glass fibre filters. The mass of each pre-ashed filter was measured and recorded before being used to filter the periphyton material. The filters with the retained periphyton material were then dried overnight at $60^{\circ} \mathrm{C}$ in an oven and weighed again to obtain the dry mass of the periphyton and filter. The mass of each filter was subtracted from the dry mass of the periphyton and filter to obtain the mass of the dried periphyton alone. The dry filters and periphyton were then frozen until being ashed at $500^{\circ} \mathrm{C}$ for 4 hours in a muffle furnace and weighed to obtain the ash mass of the periphyton and filter. To calculate AFDM of the periphyton per unit area of rock, the ashed mass of periphyton was subtracted from the corresponding dry mass of periphyton and divided by $60 \%$ of the surface area of the rock (Chételat et al. 2000).

To further characterize periphyton biomass, percent organic matter of the periphyton sample was calculated as the percent of AFDM relative to the total dry mass, and percent chlorophyll-a was calculated as the mass of chlorophyll-a relative to the AFDM of the sample. Percent organic matter indicates the proportion of the periphyton matrix that is composed of organic material, relative to inorganic material such as sediment. Percent chlorophyll-a provides an indication of the proportion of photosynthetic algae found in the periphyton matrix; if this percentage is low, this suggests a high proportion of heterotrophic organisms or detritus in the periphyton sample (Chételat et al. 2000).

All statistical analyses were conducted using the software R (R Core Team 2019), all graphs were produced in R using the ggplot2 package (Wickham 2016), and the map 
was created using ArcGIS Pro (version 2.1.0). To determine if there were long-term trends in water quality indicators in the Rideau River, a linear regression model was used to examine if there was a significant change in the PWQMN TP, chloride, and TN concentrations between 2000 and 2018 for each of the six PWQMN stations (A-F). Linear regression models were also used to quantify the 2019 spatial trends in nutrient levels (TP) and periphyton biomass (chlorophyll-a and AFDM) in relation to distance

downstream. Total phosphorus, chlorophyll-a, and AFDM data were $\log _{10}$ transformed to meet the assumptions of linear regressions.

To examine temporal variation of nutrient levels (TP) and periphyton biomass (chlorophyll-a and AFDM) in relation to distance downstream, an analysis of covariance (ANCOVA) was carried out using year (1995 and 2019) as the covariate. To characterize the relationship between chlorophyll-a and AFDM with respect to water current velocity, a linear regression model was used for both the 1995 and 2019 datasets. Finally, linear regression models were used to assess if chlorophyll-a and AFDM were related to TP and TKN for the 2019 dataset to determine if nutrient levels influenced the measures of periphyton biomass in the Rideau River.

\subsection{RESULTS}

The mean TP concentration from 2000 to 2018 at all PWQMN stations combined was $28.4 \mu \mathrm{g} / \mathrm{L}$ (median $25.0 \mu \mathrm{g} / \mathrm{L}$ ), with $33 \%$ of samples having a concentration of TP of $30.0 \mu \mathrm{g} / \mathrm{L}$ or greater, exceeding the Ontario Provincial Water Quality Objective for the protection of aquatic life in streams (OMEE 1994). Only four samples had TP concentrations above $100 \mu \mathrm{g} / \mathrm{L}$, one at Station A $(162.0 \mu \mathrm{g} / \mathrm{L})$ and three at Station F $(160.0,116.0$, and $107.0 \mu \mathrm{g} / \mathrm{L})$, all of which were collected between July and November. 
From 2000 to 2018 there were significant declines in TP concentration at the two midstream PWQMN stations (Station C: $\mathrm{r}^{2}=0.060, \mathrm{p}=0.0017$; and Station D: $\mathrm{r}^{2}=$ $0.031, \mathrm{p}=0.029)$ whereas the other four stations showed no significant change in TP (Station A: $\mathrm{r}^{2}=0.0061, \mathrm{p}=0.34 ;$ Station B: $\mathrm{r}^{2}=0.0070, \mathrm{p}=0.31$; Station E: $\mathrm{r}^{2}=0.023, \mathrm{p}$ $=0.058 ;$ Station F: $\mathrm{r}^{2}=0.00015, \mathrm{p}=0.88 ;$ Figure 3-3a).

The mean chloride concentration from 2000 to 2018 at all PWQMN stations combined was $19.8 \mathrm{mg} / \mathrm{L}$ (median of $15.9 \mathrm{mg} / \mathrm{L}$ ). The greatest chloride concentrations $(80.0 \mathrm{mg} / \mathrm{L}$ and $92.6 \mathrm{mg} / \mathrm{L})$ were both measured at Station D in November 2016 and 2018, respectively. In contrast to TP and TN, chloride concentrations significantly increased at three of the six PWQMN stations between 2000 and 2018 (Station C: $\mathrm{r}^{2}=$ $0.16, \mathrm{p}=9.40 \times 10^{-7} ;$ Station D: $\mathrm{r}^{2}=0.15, \mathrm{p}=3.31 \times 10^{-6} ;$ Station F: $\mathrm{r}^{2}=0.030, \mathrm{p}=$ 0.041; Figure 3-3b). Meanwhile, the rural, upstream stations and Station E did not show significant changes to chloride concentration between 2000 and 2018 (Station A: $\mathrm{r}^{2}=$ 0.00017, $\mathrm{p}=0.88$; Station B: $\mathrm{r}^{2}=0.13, \mathrm{p}=0.19$; Station E: $\mathrm{r}^{2}=0.00020, \mathrm{p}=0.87$ ).

The mean TN concentration from 2000 to 2018 at all PWQMN stations combined was $0.60 \mathrm{mg} / \mathrm{L}$ (median $=0.59 \mathrm{mg} / \mathrm{L}$ ). From 2000 to $2018 \mathrm{TN}$ concentrations significantly declined over at 3 PWQMN stations (Station A: $\mathrm{r}^{2}=0.049, \mathrm{p}=0.013$; Station B: $\mathrm{r}^{2}=0.036, \mathrm{p}=0.036$; Station $\left.\mathrm{E}: \mathrm{r}^{2}=0.12, \mathrm{p}=6.73 \times 10^{-5}\right)$, while the midstream stations, where there was a significant decline in TP experienced no significant change in TN over the monitoring period (Station C: $\mathrm{r}^{2}=0.011, \mathrm{p}=0.24$; Station D: $\mathrm{r}^{2}=6.27 \times 10^{-5}, \mathrm{p}=0.93$; and Station F: $\mathrm{r}^{2}=0.0077, \mathrm{p}=0.34$; Figure 3-3c). 
a)
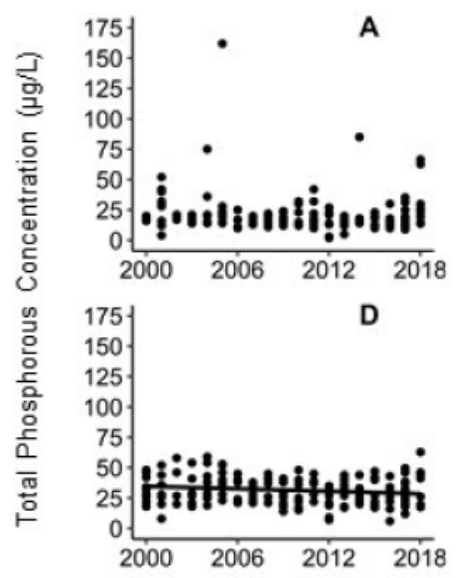

b)

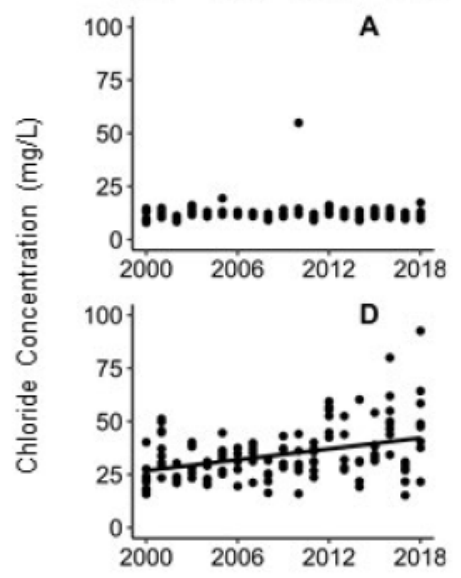

c)

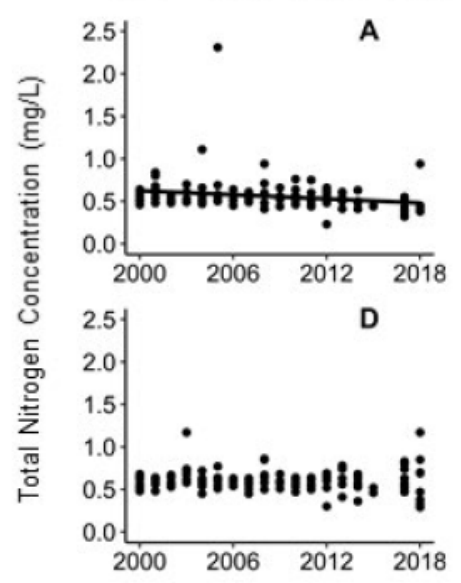

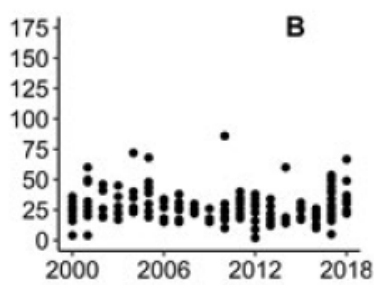
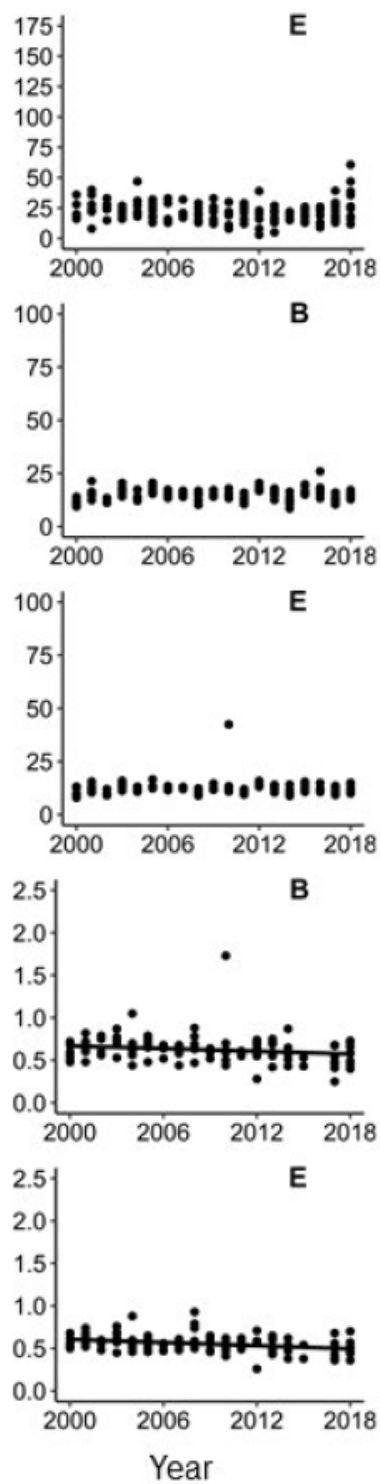
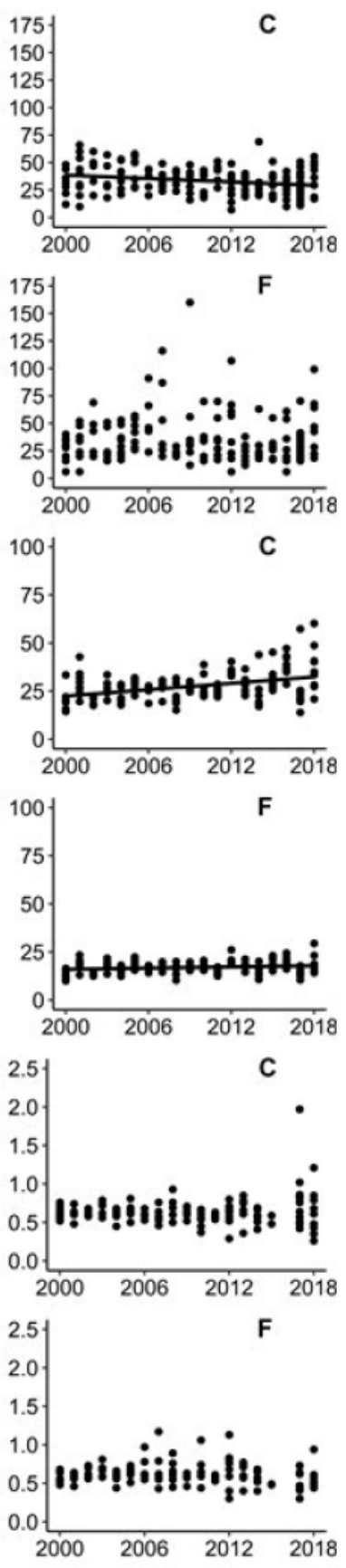

Figure 3-3. The concentration of total phosphorus (a), chloride (b) and total nitrogen (c) at the six provincial water quality monitoring stations (A-F) in the Rideau River in Ontario, Canada between 2000 and 2018 with trendlines showing significant relationships. Stations are in order from upstream to downstream (top-right to bottomleft). Data acquired from the Ontario Provincial (Stream) Water Quality Monitoring Network (OMECC 2018). a) Station C: $\mathrm{r}^{2}=0.060, \mathrm{p}=0.0017$; Station D: $\mathrm{r}^{2}=0.031, \mathrm{p}=$ 0.029 . b) Station $C: r^{2}=0.16, p=9.40 \times 10^{-7}$; Station $D: r^{2}=0.15, p=3.31 \times 10^{-6}$;

Station F: $r^{2}=0.030, p=0.041$. c) Station A: $r^{2}=0.049, p=0.013$; Station $B: r^{2}=0.036$, $\mathrm{p}=0.036$; Station $\mathrm{E}: \mathrm{r}^{2}=0.12, \mathrm{p}=6.73 \times 10^{-5}$. 
When data from all periphyton sampling sites were combined, chemical and physical variables measured in 2019 exhibited modest declines compared with those observed by Chételat et al. (2000) in 1995 (Table 3-1). With data from all sampling sites combined, chlorophyll-a (1995: $\left.49 \pm 4 \mathrm{mg} / \mathrm{m}^{2} ; 2019: 53 \pm 3 \mathrm{mg} / \mathrm{m}^{2}\right)$, AFDM (1995: $12 \pm$ $\left.0.6 \mathrm{~g} / \mathrm{m}^{2} ; 2019: 13 \pm 0.6 \mathrm{~g} / \mathrm{m}^{2}\right)$, and the percentage of chlorophyll a in organic matter (1995: $0.39 \pm 0.02 \% ; 2019: 0.43 \pm 0.01 \%$ ) showed very little change between 1995 and 2019 (Table 3-1).

Table 3-1. Comparison of biological, chemical, and physical parameters (mean $\pm \mathrm{SE}$ ) and sample sizes (n) between data collected in 1995 (Chételat et al. 2000) and 2019.

\begin{tabular}{lcccc}
\hline & 1995 & $\mathrm{n}$ & 2019 & $\mathrm{n}$ \\
\hline $\mathrm{pH}$ & $8.4 \pm 0.08$ & 14 & $8.3 \pm 0.02$ & 28 \\
Conductivity $(\mu \mathrm{S} / \mathrm{cm})$ & $368 \pm 11$ & 14 & $314 \pm 7$ & 28 \\
Current Velocity $(\mathrm{m} / \mathrm{s})$ & $0.42 \pm 0.02$ & 112 & $0.30 \pm 0.03$ & 112 \\
Total Phosphorus $(\mu \mathrm{g} / \mathrm{L})$ & $39 \pm 2$ & 33 & $33 \pm 2$ & 28 \\
Total Kjeldahl Nitrogen $(\mathrm{mg} / \mathrm{L})$ & $0.85 \pm 0.41$ & $888^{*}$ & $0.61 \pm 0.01$ & 28 \\
Ash-Free Dry Mass $\left(\mathrm{g} / \mathrm{m}^{2}\right)$ & $12 \pm 0.6$ & 112 & $13 \pm 0.6$ & 112 \\
Chlorophyll-a $\left(\mathrm{mg} / \mathrm{m}^{2}\right)$ & $49 \pm 4$ & 112 & $53 \pm 3$ & 112 \\
\% Chlorophyll-a in Organic Matter & $0.39 \pm 0.02$ & 112 & $0.43 \pm 0.01$ & 112 \\
\% Organic Matter & $34 \pm 2$ & 112 & $30 \pm 1$ & 112 \\
\hline
\end{tabular}

*TKN concentrations were obtained directly from the City of Ottawa which resulted in a much higher sample size compared to measurements of TP by Chételat et al. (2000) in 1995.

There was no significant relationship between water TP concentration and periphyton chlorophyll-a concentrations $\left(\mathrm{r}^{2}=0.14, \mathrm{p}=0.19, \mathrm{n}=14\right)$, nor between TP and $\operatorname{AFDM}\left(\mathrm{r}^{2}=0.15, \mathrm{p}=0.17, \mathrm{n}=14\right.$; Figure 3-4). Similarly, there were no significant relationships between TKN and chlorophyll-a $\left(\mathrm{r}^{2}=0.094, \mathrm{p}=0.29, \mathrm{n}=14\right)$, nor between 
TKN and AFDM $\left(r^{2}=0.18, p=0.13, n=14\right)$. In both 1995 and 2019, no relationship between TP and distance downstream was observed in the Rideau River $\left(1995: \mathrm{r}^{2}=0.12\right.$, $\mathrm{p}=0.065, \mathrm{n}=29 ; 2019: \mathrm{r}^{2}=0.082, \mathrm{p}=0.14, \mathrm{n}=28 ;$ Figure 3-5A). The largest variation in water TP concentration between years occurred at sites 2 and 3 (Figure 3-5A). Similar to TP, TKN concentrations in the Rideau River showed no linear relationship with distance downstream in $2019\left(\mathrm{r}^{2}=0.0097, \mathrm{p}=0.62, \mathrm{n}=28\right)$. 


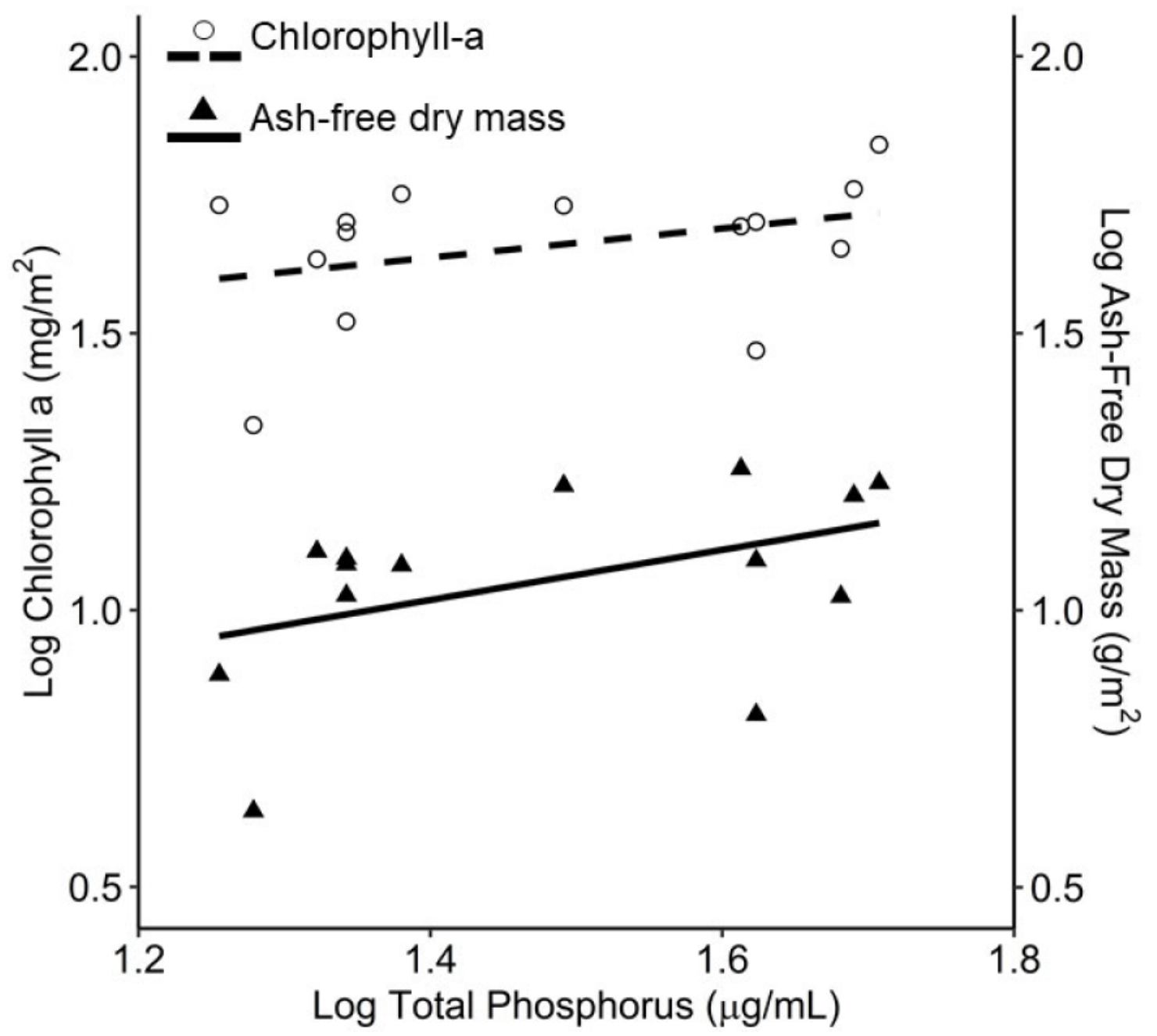

Figure 3-4. The log concentration of chlorophyll-a (open circles, dashed line) and ashfree dry mass (AFDM; black triangles, solid line) with trendlines with respect to total phosphorus collected in the Rideau River, Ontario, Canada in 2019. Each point provides the mean chlorophyll-a or ash-free dry mass for eight rocks at each site on one sampling date (June 4 or August 2, 2019), and the mean total phosphorus concentration of three water samples collected at each site on the corresponding sampling date (June 4 or August 2, 2019). Chlorophyll-a: $\mathrm{r}^{2}=0.14, \mathrm{p}=0.19 ;$ AFDM: $\mathrm{r}^{2}=0.15, \mathrm{p}=0.17$.

In contrast, conductivity had a significant increasing trend with distance downstream in both 1995 and $2019\left(1995: \mathrm{r}^{2}=0.93, \mathrm{p}=0.00045, \mathrm{n}=28 ; 2019 ; \mathrm{r}^{2}=0.86\right.$, $\mathrm{p}=0.0026, \mathrm{n}=28$; Figure 3-5B). An ANCOVA indicated a significant difference in the intercept $(\mathrm{p}=0.0027)$ between conductivity and distance downstream in 1995 compared to 2019 , while the slope did not significantly differ $(\mathrm{p}=0.056)$. 
In 1995, there was a significant increase in chlorophyll-a concentration with distance downstream in the Rideau River $\left(\mathrm{r}^{2}=0.071, \mathrm{p}=0.0046, \mathrm{n}=112\right)$, however this trend was no longer significant in $2019\left(r^{2}=0.028, p=0.078, n=112\right.$; Figure 3-5C), suggesting a slight homogenization of periphyton biomass over this stretch of the river. An ANCOVA indicated a significant difference in the intercept of the relationship between chlorophyll-a and distance downstream in 1995 compared to 2019, however the slope did not differ between years (intercept: $\mathrm{p}=0.029$; slope: $\mathrm{p}=0.26$ ).

Similarly, there was a significant increasing trend in AFDM with distance downstream in $1995\left(\mathrm{r}^{2}=0.086, \mathrm{p}=0.0017, \mathrm{n}=112\right)$, however this spatial trend was not evident in $2019\left(\mathrm{r}^{2}=0.00011, \mathrm{p}=0.91, \mathrm{n}=112\right.$; Figure 3-5D $)$. In addition, an ANCOVA indicated a significant difference in the slope of the relationship between AFDM and distance downstream in 1995 compared to $2019(\mathrm{p}=0.033)$, however the intercept did not significantly differ between years $(\mathrm{p}=0.38)$. The changes in both chlorophyll-a and AFDM from 1995 to 2019 were most apparent at the upstream and midstream sites (sites 1,2 and 3) compared to downstream sites, which corresponds with the stretch of the river that has experienced significant changes in PWQMN data for TP, chloride, and TN. 

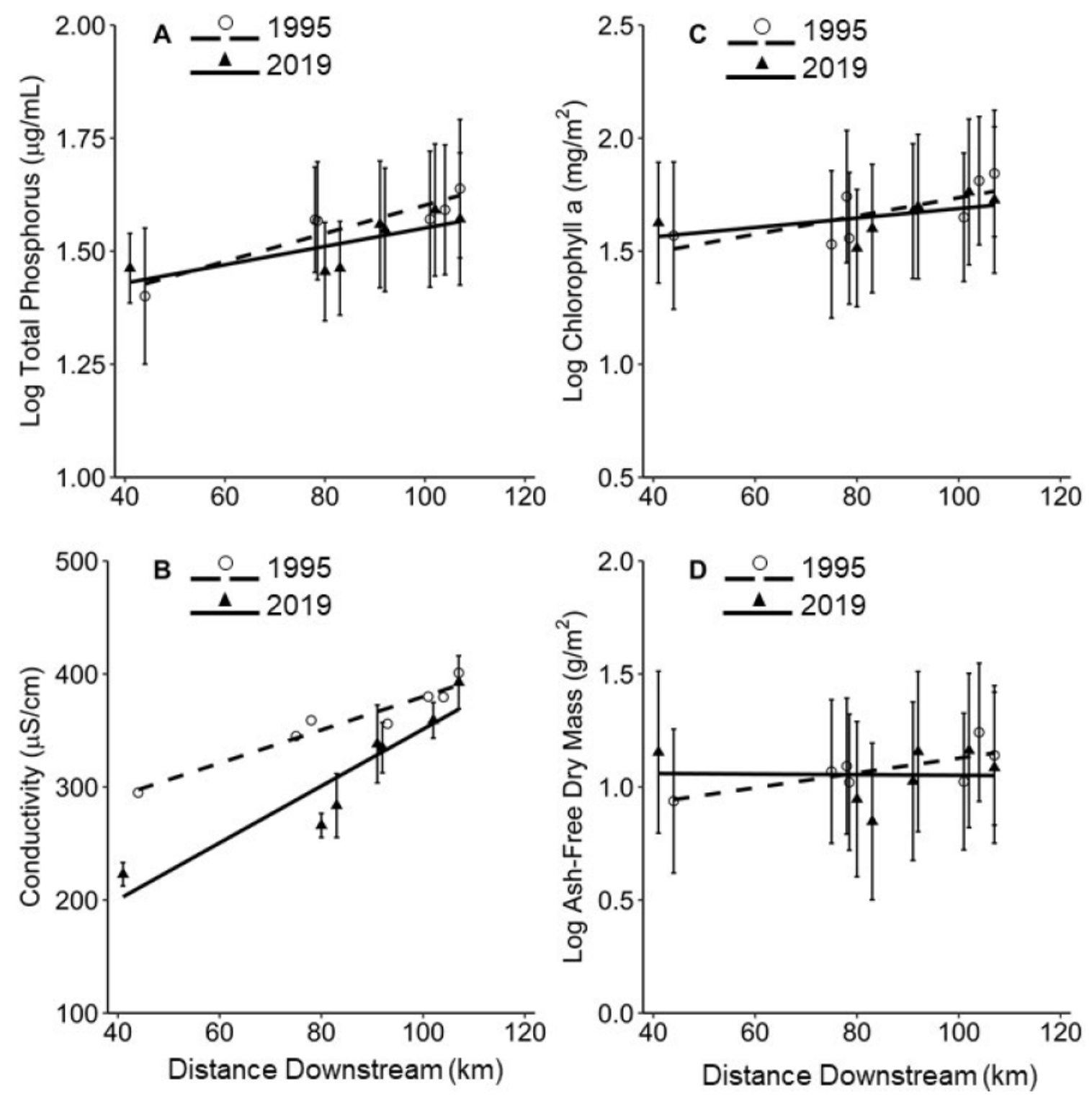

Figure 3-5. The log concentration of total phosphorus (A), conductivity (B), log concentration of chlorophyll-a (C), and log ash-free dry mass (D) with trendlines in 1995 (open circles, dashed line; Chételat et al. 2000) and 2019 (black triangles, solid line) with respect to distance downstream in the Rideau River in Ontario, Canada. A) 1995: $\mathrm{r}^{2}=$ $0.12, \mathrm{p}=0.065 ; 2019: \mathrm{r}^{2}=0.082, \mathrm{p}=0.14$. B) $1995: \mathrm{r}^{2}=0.93, \mathrm{p}=0.00045 ; 2019 ; \mathrm{r}^{2}=$ $0.86, \mathrm{p}=0.0026$. C) 1995: $\mathrm{r}^{2}=0.071, \mathrm{p}=0.0046 ; 2019: \mathrm{r}^{2}=0.028, \mathrm{p}=0.078$. D) 1995: $\mathrm{r}^{2}=0.086, \mathrm{p}=0.0017,2019: \mathrm{r}^{2}=0.00011, \mathrm{p}=0.91$. 


\subsection{DISCUSSION}

This study suggests that midstream areas in the Rideau River have experienced declines in TP and increases in chloride over the past 24 years. Declines in TP at midstream locations may be a result of land-use change, specifically the recent urbanization of the suburbs around Ottawa, while increases in chloride occurred at midstream locations which were not urbanized in the 1990s. There were no spatial relationships found between AFDM, nor chlorophyll-a with increasing distance downstream in 2019, whereas periphyton biomass showed a significant increase with distance downstream in 1995 (Chételat et al. 2000), suggesting that periphyton biomass in the Rideau River has become more uniform along this stretch of the river.

Together, declines in TP concentration and increases in chloride concentration have been attributed to land-use changes trending towards urbanization with more impervious surfaces (Nagy et al. 2012). A shift towards less agricultural and more urban land may be partially responsible for decreases in $\mathrm{TP}$, as applications of fertilizers or manure are reduced (Roberts et al. 2009). Evidence of declines in river TP concentrations have been noted in large scale studies across the United States and Sweden (Alexander and Smith 2006; Huser et al. 2018). Increasing conductivity and chloride concentrations have long been associated with urbanization, particularly in regions that experience cold winters with heavy precipitation, such as our study region, because $\mathrm{NaCl}$ is applied to roads as a de-icing agent (Godwin et al. 2003; Paul and Meyer 2001), and can result in increased chloride concentrations throughout the year (Corsi et al. 2015). Furthermore, as agricultural land is lost and we make way for greater impervious surfaces through urbanization, the movement of road salts and metals into waterways is heightened (Bazinet et al. 2010; Kaushal et al. 2005). 
The co-occurrence of declining TP concentrations and increasing chloride concentrations has also been found in recent analyses of Ontario streams. Among 113 stream sites in southern Ontario, $69 \%$ of the sites showed significant declines in TP concentration while $95 \%$ of sites showed significant increases in chloride concentration between 1975 and 2010 (Raney and Eimers 2014). The urbanization of agricultural land was considered the leading cause for the co-occurrence of decreasing TP and increasing chloride (Raney and Eimers 2014). Similar results were also described in an analysis of PWQMN data across 56 streams in Ontario by Stammler et al. (2017), where median TP concentration during the growing season (April to November) declined at $57 \%$ of streams between 1979 and 2011, and chloride concentrations increased at $88 \%$ of sites (Stammler et al. 2017).

Land use in southern Ontario has been progressing towards less agriculture in recent years (Hofmann et al. 2005), potentially reducing non-point source inputs of nitrogen into rivers (Carpenter et al. 1998). In the Rideau River concentrations of TN declined between 2000 and 2018 at rural, upstream PWQMN stations along the Rideau River.

In 1995, both AFDM and chlorophyll-a showed significant increasing trends with distance downstream (Chételat et al. 2000), however, in 2019, there were no longitudinal patterns in AFDM or chlorophyll-a with distance downstream in the Rideau River, suggesting that periphyton production in the Rideau River is more spatially uniform than it was in 1995. This highlights the importance of long-term monitoring across larger river reaches because a lack of interannual variation at a single site may not reflect ecosystemscale responses. 
While there are many studies examining long-term trends in nutrient and chloride concentrations, long-term changes in periphyton biomass are not well documented. A 16year study (1980-1996) on the Bow River in Alberta, Canada found that periphyton biomass declined in response to improved nutrient (phosphorus, nitrogen) removal at two wastewater treatment plants, but only at sites with ambient TP of $10 \mu \mathrm{g} / \mathrm{L}$ or less (Sosiak 2002). However, when ambient TP concentrations were between $10-33 \mu \mathrm{g} / \mathrm{L}$, periphyton biomass did not change as a response to declines in TP (Sosiak 2002). In the Rideau River, TP concentration generally ranged between 27.49 and $29.42 \mu \mathrm{g} / \mathrm{L}(95 \%$ Confidence Interval), and values below $10 \mu \mathrm{g} / \mathrm{L}$ have been recorded during the growing season. Moving forward, it will be interesting to observe if periphyton biomass changes substantially at sites with TP concentrations continually below $10 \mu \mathrm{g} / \mathrm{L}$ during the growing season.

Elevated concentrations of chloride have also been shown to increase periphyton biomass by causing reductions to zooplankton populations, however this has only been shown at chloride concentrations over $600 \mathrm{mg} / \mathrm{L}$ sustained over an 8-week period (Van Meter et al. 2011). However, chloride concentrations never exceeded $95 \mathrm{mg} / \mathrm{L}$ in the present study, which is well below concentrations that are harmful to aquatic life over long-term exposure periods (CCME 2011).

In addition to the impacts of chemical and physical factors, periphyton biomass can also be altered by biological factors, such as the introduction of invasive species (Strayer et al. 1999). Zebra mussels can impact periphyton directly through competition for space (Stević et al. 2013) and indirectly by increasing water clarity (MacIsaac 1996). Many rocks sampled for periphyton were covered with zebra mussels in 2019; in some cases, 
upwards of 100 zebra mussel shells could be counted on a single fist-sized rock. This was not the case in 1995 when Chételat et al. (2000) collected periphyton samples, as zebra mussels were not observed upstream of Kars, Ontario (Martel and Madill 2018). Surprisingly, increasing zebra mussel density appears to have had little impact on periphyton biomass at our study sites.

Periphyton plays an important role in freshwater ecosystems; acting as the basis of benthic aquatic food webs and providing essential habitat for small organisms (Vadeboncoeur and Power 2017; Vander Zanden and Vadeboncoeur 2020). It is important that we continue to enhance our understanding of how periphyton biomass responds to long-term environmental changes to better predict the long-term response of river ecosystems to human disturbance.

The results of this study suggest that periphyton biomass has become increasingly uniform in the Rideau River compared to 24 years ago, with periphyton biomass increasing in the upstream sections of the river and declining in midstream sections. These changes may be tied to modest shifts in local nutrient and chloride concentrations observed near these sites. To better understand how riverine ecosystems respond to cumulative environmental stressors, it is important that we monitor periphyton biomass in freshwater ecosystems to identify long-term, ecosystem-scale shifts. 


\section{DRIVERS OF PHYTOPLANKTON ABUNDANCE, BIOMASS, AND COMMUNITY COMPOSITION IN THE RIDEAU CANAL, ONTARIO, CANADA}

Lindsay L. Trottier ${ }^{1}$, Adam K. J. Williamson ${ }^{2}$, Paul B. Hamilton ${ }^{3}$, Chantal Vis ${ }^{4}$, and Jesse C. Vermaire ${ }^{1,2}$

${ }^{1}$ Department of Geography and Environmental Studies, Carleton University, Ottawa, Ontario, Canada, K1S 5B6

${ }^{2}$ Institute for Environmental and Interdisciplinary Sciences, Carleton University, Ottawa, Ontario, Canada, K1S 5B6

${ }^{3}$ Canadian Museum of Nature, Natural Heritage Campus, Gatineau, Québec, Canada, J9J 3N7

${ }^{4}$ Parks Canada, Marine Policy Division, Protected Areas Establishment and Conservation Directorate, Parks Canada, Gatineau, Quebec, Canada, J8X 0B3

This paper is intended for submission to the journal Freshwater Biology. 


\subsection{INTRODUCTION}

Biodiversity in freshwater ecosystems is declining at an alarming rate (e.g., Desforges et al. 2021; Dudgeon et al. 2006) and is driven by many factors, including climate change, nutrient loading, habitat degradation, and invasive species (e.g., Reid et al. 2019). Maintaining biodiversity at all levels of a food web is essential, as declines in phytoplankton biodiversity have been attributed to top-down pressure from predators (Carpenter et al. 1985; Paine 1966) and declines in phytoplankton species richness can reduce whole-ecosystem function through bottom-up interactions (Cardinale et al. 2006; McQueen et al. 1986). To determine how local processes shape regional patterns of biodiversity, species diversity over multiple spatial scales (global, continental, regional, and local) must be studied (Gaston 2000).

The ubiquitous global distribution of algae is described by the Baas Becking (1934) hypothesis that "everything is everywhere, but the environment selects" (Fontaneto 2011). In terms of metacommunity ecology, a community composition structured by environmental drivers is described by the species-sorting perspective (Leibold et al. 2004). As such, phytoplankton composition and biomass are representative of the chemical characteristics of their environment, especially concentrations of phosphorus and nitrogen, and are key indicators of the quality of their environment (Carvalho et al. 2013; Wu et al. 2014). In addition to nutrients, phytoplankton can also be sensitive to changes in their physical environment, such as light availability, water temperature, and water flow rates (e.g., Reynolds 1989, 2000). Biological factors such as grazing and competition for nutrients also drive phytoplankton biomass and community composition (Padisák et al. 2010; Sommer et al. 1986). 
Although phytoplankton community composition in fresh water is largely affected by environmental factors, purely spatial factors (i.e. relating to dispersal) can also play a role in structuring the community (Soininen 2007; Soininen and Weckström 2009). In metacommunity ecology, the neutral perspective describes a community composition shaped by the ability of the species to disperse into a given ecosystem (Leibold et al. 2004). When spatial controls are considered, phytoplankton biomass in the Rideau River generally demonstrates a second-order polynomial relationship with increasing distance from the headwater lake (Basu and Pick 1997; Hamilton et al. 2012, 2011).

Phytoplankton community composition in the Rideau River demonstrated an inverse relationship between biodiversity and distance downstream (Hamilton et al. 2011), and phytoplankton cell size increased with distance (Yang et al. 1997).

A spatially-structured environment also exists and can be described by the River Continuum Concept, whereby the physical conditions of the environment drives the biological and chemical conditions in an upstream to downstream gradient (Vannote et al. 1980). However, in an altered and heavily regulated waterway such as the Rideau Canal, this upstream-downstream continuum may also be altered and further complicated by the unnatural flow regime.

Furthermore, the scale over which phytoplankton and their environment are studied also affects the relationships identified (Harris 1980). For example, at regional scale, $\mathrm{pH}$ alone explains more variability in diatom community composition than spatial factors, whereas at broader, intra-continental scale spatial factors explain more variability than environmental factors (Bennett et al. 2010). In large scale studies of riverine systems across southern Ontario and western Quebec, Canada, phytoplankton biomass and 
community composition are structured by nutrients, and not the physical aspects of the environment such as water residence time and light (Basu and Pick 1996; Chételat et al. 2006). At a smaller regional scale, studies examining phytoplankton in the Rideau River, Ontario, Canada demonstrated that nutrients still play a role in formation of algal biomass (Basu and Pick 1997) and community composition (Hamilton et al. 2011), but the physical environment also impacted biomass and community composition (Hamilton et al. 2012).

Previous studies have examined the spatial patterns of phytoplankton and environmental factors at local scale $(100 \mathrm{~km})$ along the Rideau River (e.g., Basu and Pick 1997; Hamilton et al. 2012, 2011; Yang et al. 1997), but to the author's knowledge these patterns and relationships have not been examined at a small regional scale $(200 \mathrm{~km})$ along the Rideau Canal, a system comprised of the Rideau and Cataraqui rivers. The present study assesses phytoplankton biomass and community composition in the Rideau Canal in 2019, and examines relationships between phytoplankton community composition and environmental (chemical and physical), temporal, and spatial variables at a small regional scale. Due to the scale of this study and the modifications arising from the construction and operation of a canal, environmental factors are expected to be the primary driver of phytoplankton biomass and community composition. However, physical characteristics and spatial controls are modified in constructed and regulated waterways such as the Rideau Canal, whereby dams and locks disrupt flow and may prevent dispersal. Consequently, the proportions of variation in community composition explained by the environment and space may be altered. This study seeks to disentangle 
the effects of environmental, temporal, and spatial variability on phytoplankton community composition in a modified, regulated waterway.

\subsection{STUDY SITE}

The Rideau Canal is $202 \mathrm{~km}$ long, stretching across southeastern Ontario, from Lake Ontario in Kingston, Ontario, Canada to the Ottawa River in Ottawa, Ontario Canada (Figure 4-1). The waterway is formed by the Cataraqui River which flows from Newboro Lake to Lake Ontario, and the Rideau River which flows from Upper Rideau Lake to the Ottawa River. The Cataraqui River watershed drains an area of approximately $900 \mathrm{~km}^{2}$, with roughly $61 \%$ of the watershed covered by woodlands, $22 \%$ by agricultural land, and only $1 \%$ by urban land (CRCA 2008). The Rideau River watershed drains 3800 $\mathrm{km}^{2}$ of land that is covered by approximately $50 \%$ natural land cover (i.e., forests, wetlands, etc.), 30\% agricultural land cover, and 12\% urban land cover (RVCA 2019). 


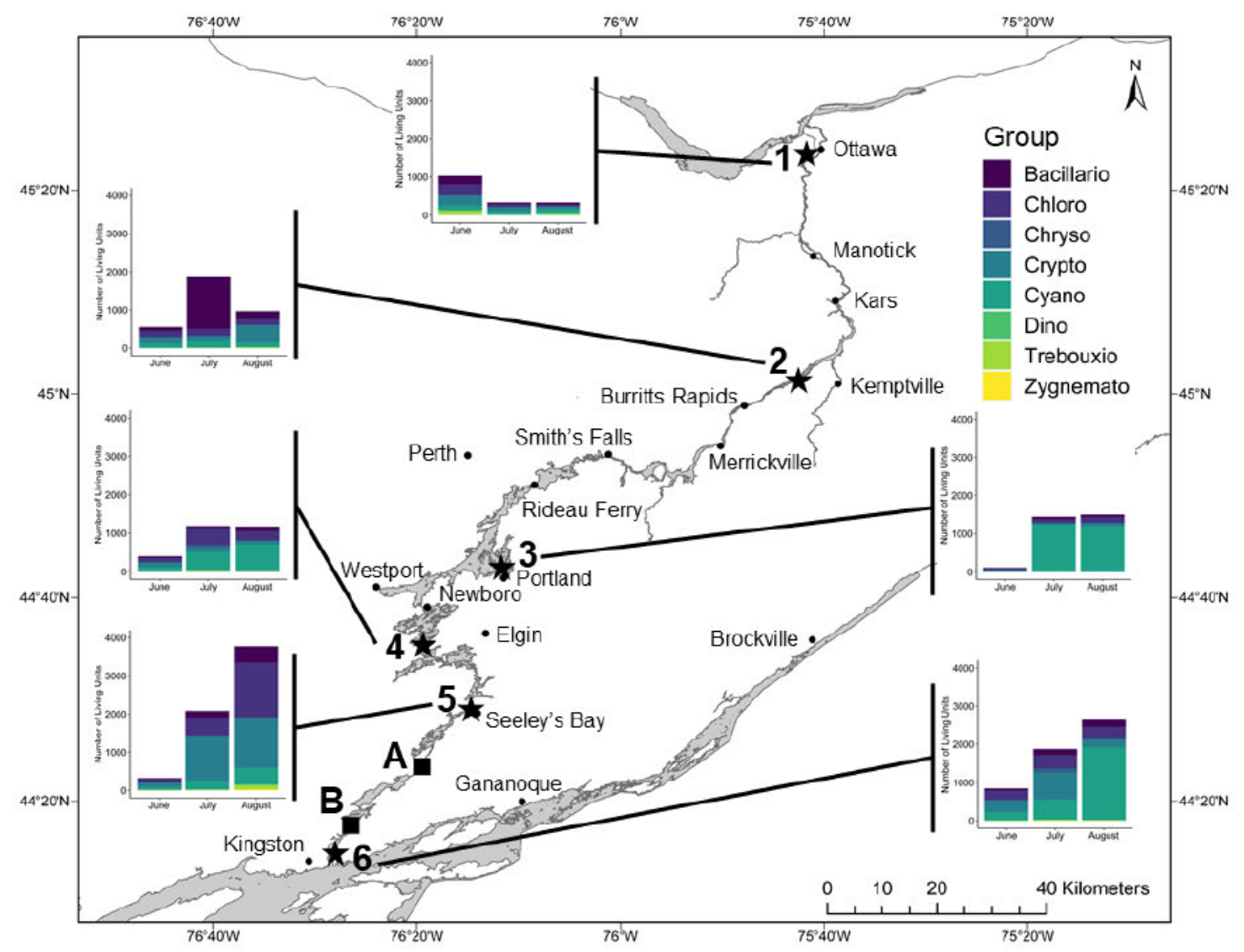

Figure 4-1. Map of the Rideau waterway in Ontario, Canada from Ottawa to Kingston with six monthly sample sites (stars; $1-6$ ) and two grab sample sites (squares; A, B). The total number of phytoplankton living units per $\mathrm{mL}$ counted in each of the eight key phytoplankton classes at monthly sample sites between June and August 2019 are presented. Map created in ArcGIS Pro 2.1.0 using geospatial data acquired from Natural Earth (2018) and Natural Resources Canada (2017).

The Rideau Canal ecosystem faces pressure from a variety of factors including climate change (Forrest et al. 2003), shoreline development (Chhor et al. 2020), nutrient loading (Karst and Smol 2000; Parks Canada 2005), and aquatic invasive species, such as Eurasian watermilfoil (Myriophyllum spicatum; Poulin 2001) and zebra mussels (Dreissenia polymorpha; Martel 1995; Martel and Madill 2018). The Rideau Canal is also biologically diverse and provides important habitat for many aquatic species and 
species at risk, such as Blanding's turtles (Emydoidea blandingii; COSEWIC 2016) and silver lamprey (Ichthyomyzon unicuspis; COSEWIC 2011).

\subsection{METHODOLOGY}

Since land-use type can be associated with water chemistry (e.g., Carpenter et al. 1998; Meador and Goldstein 2003), sample sites were selected for water chemistry and phytoplankton analyses in the Rideau Canal based on surrounding land-use type. Landuse type was assessed based on land-use maps produced by the Rideau Valley Conservation Authority (RVCA, 2019) and a watershed characterization map produced by the Cataraqui Region Conservation Authority (CRCA, 2008). Six sites were selected for sampling from three land-use types: three sites surrounded by agricultural land (sites 2,5 , and A), two sites surrounded by recreational land (mainly forested with some shoreline development; sites 3 and 4), and three sites surrounded by urban land (sites 1, 6, and B). Water samples were collected from sites $1-6$ once a month in June $(25-28)$, July $(29-31)$, and August $(24-29), 2019$. Water samples were collected once (grabsample sites) on August 24, 2019, from the Lower Brewers (A) and Kingston Mills lock stations (B).

Triplicate water samples were collected at each of the monthly sample sites $(1-6)$ and one water sample was collected at each grab sample sites (A and B). Water depth (m) and Secchi depth (m) were measured for each sample, and a YSI ProPlus Multiparameter Instrument was used to measure water temperature $\left({ }^{\circ} \mathrm{C}\right)$, conductivity $(\mu \mathrm{S} / \mathrm{cm})$, dissolved oxygen concentration $(\mathrm{DO} ; \mathrm{mg} / \mathrm{L})$, and $\mathrm{pH}$. To minimize variation in phytoplankton community composition and abundance caused by differences in light availability and to ensure phytoplankton were collected at a depth with adequate light for photosynthesis, 
water samples for nutrient and algal analysis were collected at 0.5 times the Secchi depth (approximately the middle of the euphotic zone; Hambrook Berkman and Canova 2007).

In the field, approximately $60 \mathrm{~mL}$ of water was filtered through a $0.45 \mu \mathrm{m}$ glass fibre filter for future analysis of dissolved organic carbon (DOC) concentration. Next, $300 \mathrm{~mL}$ of water was decanted into a sterile bottle to be sent to the City of Ottawa Environmental Services Department Water Chemistry Laboratory for analysis of total phosphorus (TP; $\mu \mathrm{g} / \mathrm{L})$ and total Kjeldahl nitrogen $(\mathrm{TKN} ; \mathrm{mg} / \mathrm{L})$ concentration. For chlorophyll-a extraction, $1.5 \mathrm{~L}$ of water was filtered through a $0.7 \mu \mathrm{m}$ glass microfibre filter (Whatman grade GF/F) using vacuum filtration. In cases when the glass fibre filter became clogged by particulate matter in the water sample, a lesser volume was used, with $300 \mathrm{~mL}$ being the lowest volume filtered. To preserve the structure of algal cells during vacuum filtration, suction pressure was maintained at or below $350 \mathrm{mmHg}$ (Paerl and Shimp 1973). Following filtration, the glass fibre filters were folded in half, placed into $15 \mathrm{~mL}$ centrifuge tubes, and wrapped in aluminum foil, then frozen in the dark until later chlorophyll-a extraction. To preserve water samples for phytoplankton analysis, $250 \mathrm{~mL}$ of water was decanted into a glass amber bottle with a small amount (approximately 10 drops) of Lugol's iodine solution before storing water samples in a refrigerator at $4{ }^{\circ} \mathrm{C}$ until later analysis (Throndsen 1978).

To quantify the concentration of DOC at each site, filtered $(0.45 \mu \mathrm{m})$ water samples were placed into a TOC-L by Shimadzu which measures DOC from water samples using combustion catalytic oxidation. Concentrations of TP and TKN were analysed by the City of Ottawa Environmental Services Department Water Chemistry Laboratory by acid digestion (COESD 2018). To determine chlorophyll-a concentration, $15 \mathrm{~mL}$ of $95 \%$ 
ethanol heated to $79^{\circ} \mathrm{C}$ was added to each tube containing the glass fibre filters, and the tubes were placed in a water bath at $79^{\circ} \mathrm{C}$ for 5 minutes in a dark room (ISO:10260, 1992). The test tubes were then removed from the water bath, wrapped in aluminum foil, and stored in a dark refrigerator at $4^{\circ} \mathrm{C}$ overnight. Approximately $5 \mathrm{~mL}$ of the chlorophyll-a solution was then filtered through a $0.45 \mu \mathrm{m}$ filter into a quartz cuvette ( 1 cm path length) and was analysed in a UV-VIS spectrophotometer (Shimadzu UV-1280) at 665 and $750 \mathrm{~nm}$. The absorbance was recorded at both wavelengths. Then, to correct for phaeophytins, $0.15 \mathrm{~mL}$ ( $1 \%$ of final volume) of $0.1 \mathrm{M} \mathrm{HCl}$ was added to each sample, and the absorbance was measured and recorded for a second time at 665 and $750 \mathrm{~nm}$. To correct for turbidity, the absorbance of both the original filtrate and the acidified filtrate at $750 \mathrm{~nm}$ were subtracted from their respective absorbance at $665 \mathrm{~nm}$. The turbiditycorrected absorbance was used to calculate the chlorophyll-a concentration $(\mu \mathrm{g} / \mathrm{L})$ using a monochromatic equation (chlorophyll-a $=29.5\left(\right.$ A665 $_{6}$ A665_acidified); Lorenzen 1967; Wintermans and De Mots 1965) taking the total volume of water filtered and the volume of ethanol used to extract the pigments into consideration to standardize the concentration.

To assess phytoplankton abundance and community composition, the phytoplankton samples preserved with Lugol's solution were processed with a FlowCam (Benchtop B4 Series) on AutoImage mode at 10X magnification, using the recommended FC100 flow cell (100 $\mu \mathrm{m}$ depth) and a LED light collimator to increase light to the flow cell. To ensure that residual particles were sufficiently flushed out of the FlowCam between phytoplankton samples, two volumes of deionized water were compared to determine the preferred flushing volume. When $5 \mathrm{~mL}$ of deionized water was used to 
flush the FlowCam between samples, particle counts decreased by $98 \%$, while a $10 \mathrm{~mL}$ flush cycle reduced particle counts by $99.8 \%$. Therefore, to effectively reduce crosscontamination, the FlowCam was flushed with $10 \mathrm{~mL}$ of deionized water between each phytoplankton sample.

Each day, the FlowCam was first flushed with $10 \mathrm{~mL}$ of deionized water (2 cycles, $5 \mathrm{~mL}$ per cycle), then primed with $10 \mathrm{~mL}$ of the phytoplankton sample (2 cycles, $5 \mathrm{~mL}$ per cycle). The FlowCam was focussed using the first phytoplankton sample of the day and adjusted if necessary, using $20 \mu \mathrm{m}$ polystyrene focusing beads. Phytoplankton samples were analysed using AutoImage mode, which captures images of the sample fluid at a regular interval as indicated by the user. For this analysis, an interval of 20 frames per second was used to analyse $5 \mathrm{~mL}$ of each phytoplankton sample. Phytoplankton abundance (counts) was established as the number of phytoplankton living units (PLUs) which may appear as colonies, filaments and individual cells (Hamilton et al. 2011).

All FlowCam files were processed using the VisualSpreadsheet software (version 4.18.16). Using a subset of 6 sample files, 25 preliminary libraries were created containing images of similar colour, shape, and size (i.e., representing a group of phytoplankton). The PLUs in these libraries were used to create a statistical or value filter. Statistical filters use the PLUs in the library to create parameters for an ideal PLU (based off colour, shape, size, etc.), then grades all the other PLUs against the ideal PLU to produce a likeness score. Living units that fall within the prescribed likeness score range are assigned to that library. Value filters are more stringent, using the actual values 
of each user-selected colour/shape/size parameter in a series of Boolean AND operations, such that PLUs must meet all the parameter conditions to be included in a library.

A classification template was then created for each sample file, with one class corresponding to each of the preliminary libraries, plus additional classes for remaining PLUs. The statistical/value filter for each of the preliminary libraries was added to the respective class, while additional classes remained without a filter. This classification template was adjusted for each file, adding additional classes as needed. The PLUs were then AutoClassified into the classes containing filters. Living units that were automatically classified were visually double-checked to ensure the classifications were accurate and PLUs that were not automatically classified were manually placed into their respective classes based on appearance. In general, the majority of PLUs were manually placed into their designated classes, as the AutoClassify function only worked well for a few classes.

Living units were first classified into 19 groups based on size and overall appearance: Bacillariophyceae, Beads (small microplastic beads used to focus the FlowCam), Chlorophyceae, Chrysophyceae, Ciliates, Cryptophyceae, Cyanophyceae, Cysts, Debris (living units that were unidentifiable, and not believed to be phytoplankton), Dinophyceae, Euglenoidea, Fungus, Other (mainly amoebas and zooplankton), Picoplankton (clusters of phytoplankton too small to classify further), Pollen, Trebouxiophyceae, Ulvophyceae, Unknown (PLUs that were unable to be identified to the class level or higher), and Zygnematophyceae. There were eight key groups used in subsequent analyses, which were the most abundant and which contained phytoplankton that were able to be identified to the class level, or lower (genus, species). 
These key groups are Bacillariophyceae (diatoms), Chlorophyceae (chlorophytes, green algae), Chrysophyceae (chrysophytes), Cryptophyceae (cryptophytes), Cyanophyceae (cyanobacteria, blue-green algae), Dinophyceae (dinophytes), Trebouxiophyceae, and Zygnematophyceae (Figure 4-2). Within each of the eight key groups, PLUs were split again into more specific sub-groups based on their genus or species, or their overall size and appearance. 


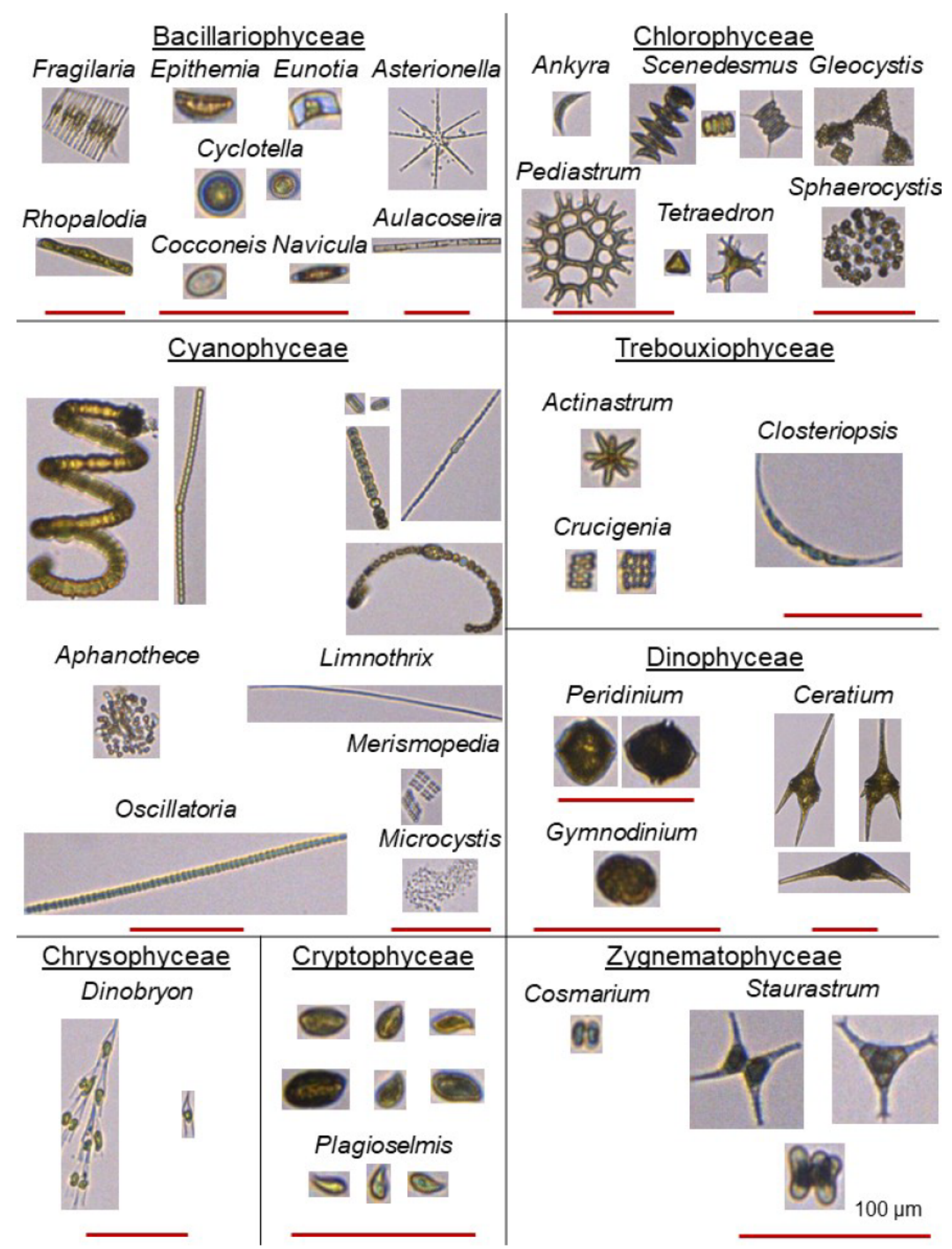

Figure 4-2. FlowCam images demonstrating the diversity of phytoplankton living units in each of the eight key phytoplankton classes. Scale bars (red) represent $100 \mu \mathrm{m}$. 
Statistical analyses were conducted in the software R (R Core Team 2019), and graphs were created in $\mathrm{R}$ using the ggplot2 package (Wickham 2016). The map was created using ArcGIS Pro (version 2.1.0). The relative abundance of each group and subgroup was calculated by dividing the number of PLUs in a given group/sub-group by the total number of PLUs in the eight key groups. Only sub-groups with a relative abundance of at least $2 \%$ in at least one sample (28 commonly occurring sub-groups) were included in principle components analysis (PCA), redundancy analysis (RDA), and variance partitioning by a partial redundancy analysis (pRDA).

A Hellinger transformation was used to reduce the influence of more common groups on rarer groups (Rao 1995). Next, a detrended correspondence analysis was used to determine if a linear or unimodal-based approach should be taken to analyse the dataset (Birks 2010). In this study, the linear ordination approach was taken because the gradient lengths were less than 2.5 (ter Braak and Prentice 1988). The data was analysed with a PCA using the package vegan (Oksanen et al. 2019) to examine relationships among phytoplankton community composition at the study sites. A broken-stick model was used to determine the number of statistically significant PCA axes that should be considered in further analyses (Jackson 1993).

Environmental variables were assessed for normality using the Shapiro-Wilks test, and $\log$ transformed if necessary. A Pearson correlation matrix calculated using the rcorr function in the Hmisc package (Harrell Jr. 2020) was used to identify highly correlated $(R>0.65)$ environmental and spatial variables. When necessary, one of the highly correlated variables was removed before conducting the RDA. A backward-selection process was used to determine which environmental, spatial, or temporal variables 
explained significant variation in the phytoplankton community and should be assessed by an RDA or pRDA. Variance partitioning was used to quantify the amount of variability in phytoplankton community assemblages explained by environmental, temporal, and spatial explanatory variables together and to determine the amount of independent variation explained by environment, space, and time independently.

\subsection{RESULTS}

Water depth varied across sites, ranging from $2.0 \mathrm{~m}$ Site A to $22.9 \pm 27.5 \mathrm{~m}$ at Site 3 (Table 4-1). Water temperatures varied from $20.8 \pm 0.3{ }^{\circ} \mathrm{C}$ at Site 3 to $27.1 \pm 0.1{ }^{\circ} \mathrm{C}$ at Site 2 and were highest at all monthly sites in July. Conductivity was lowest in the agricultural setting of Site $5(172.8 \pm 1.3 \mu \mathrm{S} / \mathrm{cm})$ and highest in the urban setting of Site 1 (462.7 $\pm 23.5 \mu \mathrm{S} / \mathrm{cm}$; Table 4-1, Figure 4-3). Dissolved oxygen was highest at Site 5 in June $(10.5 \pm 1.2 \mathrm{mg} / \mathrm{L})$ and lowest at Site 2 in August $(6.6 \pm 0.1 \mathrm{mg} / \mathrm{L})$. At all sites, $\mathrm{pH}$ was relatively stable, varying between 8.3 at Site 2 and 9.2 Site B.

In terms of nutrients, DOC was lowest at Site 3 in June $(1.7 \pm 1.0 \mathrm{mg} / \mathrm{L})$ and highest at Site 2 in June $(5.0 \pm 0.5 \mathrm{mg} / \mathrm{L})$. Concentrations of TP were lowest at Site 3 in August $(8.3 \pm 1.5 \mu \mathrm{g} / \mathrm{L})$ and highest at Site 1 in August $(48.7 \pm 15.0 \mu \mathrm{g} / \mathrm{L})$. Similarly, Site 3 had the lowest concentration of TKN $(0.3 \mathrm{mg} / \mathrm{L}$ in August), while Site A had the highest concentration of TKN $(0.9 \mathrm{mg} / \mathrm{L})$. Among the sites that were sampled monthly, chlorophyll-a ranged from $0.6 \pm 0.3 \mu \mathrm{g} / \mathrm{L}$ at Site 3 (July) to $6.8 \pm 5.7 \mu \mathrm{g} / \mathrm{L}$ at Site 5 (August). In comparison, chlorophyll-a concentration at grab sample at sites A and B was much higher, $19.2 \pm 4.9 \mu \mathrm{g} / \mathrm{L}$ and $14.2 \pm 2.4 \mu \mathrm{g} / \mathrm{L}$, respectively. Secchi depths ranged from $0.6 \mathrm{~m}$ at Site B to $5.4 \pm 1.7 \mathrm{~m}$ at Site 5. In general, sites that had higher nutrient concentrations (TP, TKN, DOC) had higher concentrations of chlorophyll-a and shallower Secchi depths (Table 4-1, Figure 4-3). 
Table 4-1. The mean ( \pm s.d.) environmental and water chemistry characteristics of the monthly (1 - 6) and grab-sample (A, B) sites by month.

\begin{tabular}{|c|c|c|c|c|c|c|}
\hline Site & Month & $\begin{array}{c}\text { Water Depth } \\
\text { (m) }\end{array}$ & $\begin{array}{c}\text { Temperature } \\
\left({ }^{\circ} \mathrm{C}\right)\end{array}$ & $\begin{array}{l}\text { Conductivity } \\
(\mu \mathrm{S} / \mathrm{cm})\end{array}$ & $\begin{array}{c}\text { Dissolved } \\
\text { Oxygen } \\
(\mathrm{mg} / \mathrm{L}) \\
\end{array}$ & pH \\
\hline \multirow{3}{*}{1} & June & $3.0 \pm 1.6$ & $24.0 \pm 0.2$ & $448.8 \pm 5.3$ & $8.7 \pm 0.6$ & $8.5 \pm 0.1$ \\
\hline & July & $3.3 \pm 1.5$ & $26.8 \pm 0.3$ & $462.7 \pm 23.5$ & $7.6 \pm 0.8$ & $8.5 \pm 0.2$ \\
\hline & August & $2.8 \pm 1.4$ & $22.6 \pm 0.6$ & $413.1 \pm 6.4$ & $8.9 \pm 0.2$ & $8.9 \pm 0.1$ \\
\hline \multirow{3}{*}{2} & June & $4.4 \pm 0.1$ & $24.0 \pm 0.5$ & $243.8 \pm 2.7$ & $6.8 \pm 0.3$ & $8.3 \pm 0.0$ \\
\hline & July & $4.2 \pm 0.9$ & $27.1 \pm 0.1$ & $254.0 \pm 0.9$ & $8.8 \pm 0.1$ & $8.7 \pm 0.0$ \\
\hline & August & $4.0 \pm 1.3$ & $22.3 \pm 0.1$ & $202.0 \pm 2.6$ & $6.6 \pm 0.1$ & $8.3 \pm 0.0$ \\
\hline \multirow{3}{*}{3} & June & $4.4 \pm 3.0$ & $20.8 \pm 0.3$ & $188.0 \pm 0.9$ & $8.4 \pm 0.5$ & $8.4 \pm 0.0$ \\
\hline & July & $7.8 \pm 3.7$ & $25.8 \pm 0.2$ & $211.6 \pm 0.6$ & $7.9 \pm 0.1$ & $8.6 \pm 0.0$ \\
\hline & August & $22.9 \pm 27.5$ & $22.8 \pm 0.2$ & $183.9 \pm 26.1$ & $7.9 \pm 0.2$ & $8.7 \pm 0.0$ \\
\hline \multirow{3}{*}{4} & June & $15.8 \pm 11.0$ & $22.9 \pm 0.1$ & $179.0 \pm 1.2$ & $8.6 \pm 0.2$ & $8.4 \pm 0.0$ \\
\hline & July & $17.2 \pm 12.0$ & $25.9 \pm 0.0$ & $193.4 \pm 0.7$ & $7.5 \pm 0.1$ & $8.8 \pm 0.0$ \\
\hline & August & $11.7 \pm 7.2$ & $23.0 \pm 0.2$ & $183.4 \pm 0.7$ & $7.6 \pm 0.3$ & $8.7 \pm 0.0$ \\
\hline \multirow{3}{*}{5} & June & $4.0 \pm 1.3$ & $24.0 \pm 0.3$ & $172.8 \pm 1.3$ & $10.5 \pm 1.2$ & $9.0 \pm 0.3$ \\
\hline & July & $3.6 \pm 0.4$ & $26.9 \pm 0.1$ & $185.4 \pm 20.3$ & $7.8 \pm 0.3$ & $9.0 \pm 0.2$ \\
\hline & August & $2.9 \pm 0.1$ & $24.0 \pm 0.2$ & $186.6 \pm 27.9$ & $7.7 \pm 0.8$ & $8.8 \pm 0.2$ \\
\hline \multirow{3}{*}{6} & June & $2.3 \pm 0.1$ & $21.7 \pm 0.4$ & $205.3 \pm 2.4$ & $9.1 \pm 0.5$ & $8.8 \pm 0.1$ \\
\hline & July & $2.3 \pm 0.1$ & $26.2 \pm 0.3$ & $257.9 \pm 0.4$ & $8.4 \pm 0.4$ & $8.8 \pm 0.2$ \\
\hline & August & $2.8 \pm 0.7$ & $22.6 \pm 0.2$ & $238.8 \pm 16.7$ & $7.7 \pm 0.3$ & $9.0 \pm 0.1$ \\
\hline A & August & 2 & 23.3 & 177.6 & 7.4 & 9.0 \\
\hline B & August & 3.5 & 23.5 & 204.3 & 7.9 & 9.2 \\
\hline
\end{tabular}


Table 4-1 (continued).

\begin{tabular}{|c|c|c|c|c|c|c|}
\hline Site & Month & $\mathrm{TP}(\mu \mathrm{g} / \mathrm{L})$ & TKN (mg/L) & DOC (mg/L) & $\begin{array}{c}\text { Chlorophyll- } \\
\text { a }(\mu \mathrm{g} / \mathrm{L})\end{array}$ & $\begin{array}{c}\text { Secchi Depth } \\
\text { (m) }\end{array}$ \\
\hline \multirow{3}{*}{1} & June & $29.0 \pm 5.6$ & $0.7 \pm 0.1$ & $4.2 \pm 1.2$ & $3.6 \pm 0.7$ & $2.3 \pm 0.4$ \\
\hline & July & $37.7 \pm 5.8$ & $0.7 \pm 0.0$ & $3.7 \pm 0.2$ & $2.4 \pm 2.8$ & $2.3 \pm 0.3$ \\
\hline & August & $48.7 \pm 15.0$ & $0.6 \pm 0.1$ & $3.9 \pm 0.3$ & $3.0 \pm 4.9$ & $2.0 \pm 0.0$ \\
\hline \multirow{3}{*}{2} & June & $31.7 \pm 2.1$ & $0.6 \pm 0.0$ & $5.0 \pm 0.5$ & $1.2 \pm 0.0$ & $1.6 \pm 0.1$ \\
\hline & July & $35.0 \pm 2.6$ & $0.7 \pm 0.1$ & $3.7 \pm 0.2$ & $4.7 \pm 1.3$ & $1.3 \pm 0.0$ \\
\hline & August & $32.0 \pm 16.5$ & $0.6 \pm 0.0$ & $3.1 \pm 0.1$ & $2.3 \pm 0.7$ & $1.6 \pm 0.1$ \\
\hline \multirow{3}{*}{3} & June & $11.3 \pm 0.6$ & $0.4 \pm 0.0$ & $1.7 \pm 1.0$ & $0.8 \pm 0.7$ & $3.7 \pm 1.8$ \\
\hline & July & $14.0 \pm 3.6$ & $0.4 \pm 0.0$ & $1.8 \pm 0.1$ & $0.6 \pm 0.3$ & $5.0 \pm 0.9$ \\
\hline & August & $8.3 \pm 1.5$ & $0.3 \pm 0.0$ & $1.8 \pm 0.2$ & $0.9 \pm 0.8$ & $5.4 \pm 1.7$ \\
\hline \multirow{3}{*}{4} & June & $13.3 \pm 0.6$ & $0.5 \pm 0.0$ & $2.7 \pm 0.3$ & $0.9 \pm 0.0$ & $4.9 \pm 1.0$ \\
\hline & July & $12.0 \pm 2.6$ & $0.4 \pm 0.0$ & $2.5 \pm 0.2$ & $1.3 \pm 0.3$ & $3.8 \pm 0.3$ \\
\hline & August & $12.0 \pm 1.0$ & $0.4 \pm 0.0$ & $2.2 \pm 0.2$ & $1.4 \pm 0.2$ & $4.1 \pm 0.5$ \\
\hline \multirow{3}{*}{5} & June & $15.3 \pm 2.5$ & $0.4 \pm 0.0$ & $2.6 \pm 0.7$ & $0.6 \pm 0.3$ & $2.3 \pm 0.3$ \\
\hline & July & $24.0 \pm 12.2$ & $0.5 \pm 0.1$ & $2.5 \pm 0.1$ & $4.7 \pm 2.1$ & $2.3 \pm 0.6$ \\
\hline & August & $35.0 \pm 22.9$ & $0.6 \pm 0.2$ & $2.6 \pm 0.3$ & $6.8 \pm 5.7$ & $1.9 \pm 0.6$ \\
\hline \multirow{3}{*}{6} & June & $20.3 \pm 0.6$ & $0.5 \pm 0.0$ & $3.3 \pm 0.4$ & $3.6 \pm 1.2$ & $1.8 \pm 0.0$ \\
\hline & July & $25.7 \pm 3.2$ & $0.5 \pm 0.0$ & $2.2 \pm 0.3$ & $6.4 \pm 2.8$ & $1.5 \pm 0.0$ \\
\hline & August & $26.3 \pm 3.8$ & $0.6 \pm 0.1$ & $2.4 \pm 0.3$ & $5.5 \pm 3.4$ & $1.8 \pm 0.6$ \\
\hline A & August & 46 & 0.9 & 2.4 & $19.2 \pm 4.9$ & 0.8 \\
\hline $\mathrm{B}$ & August & 48 & 0.8 & 2.6 & $14.2 \pm 2.4$ & 0.6 \\
\hline
\end{tabular}



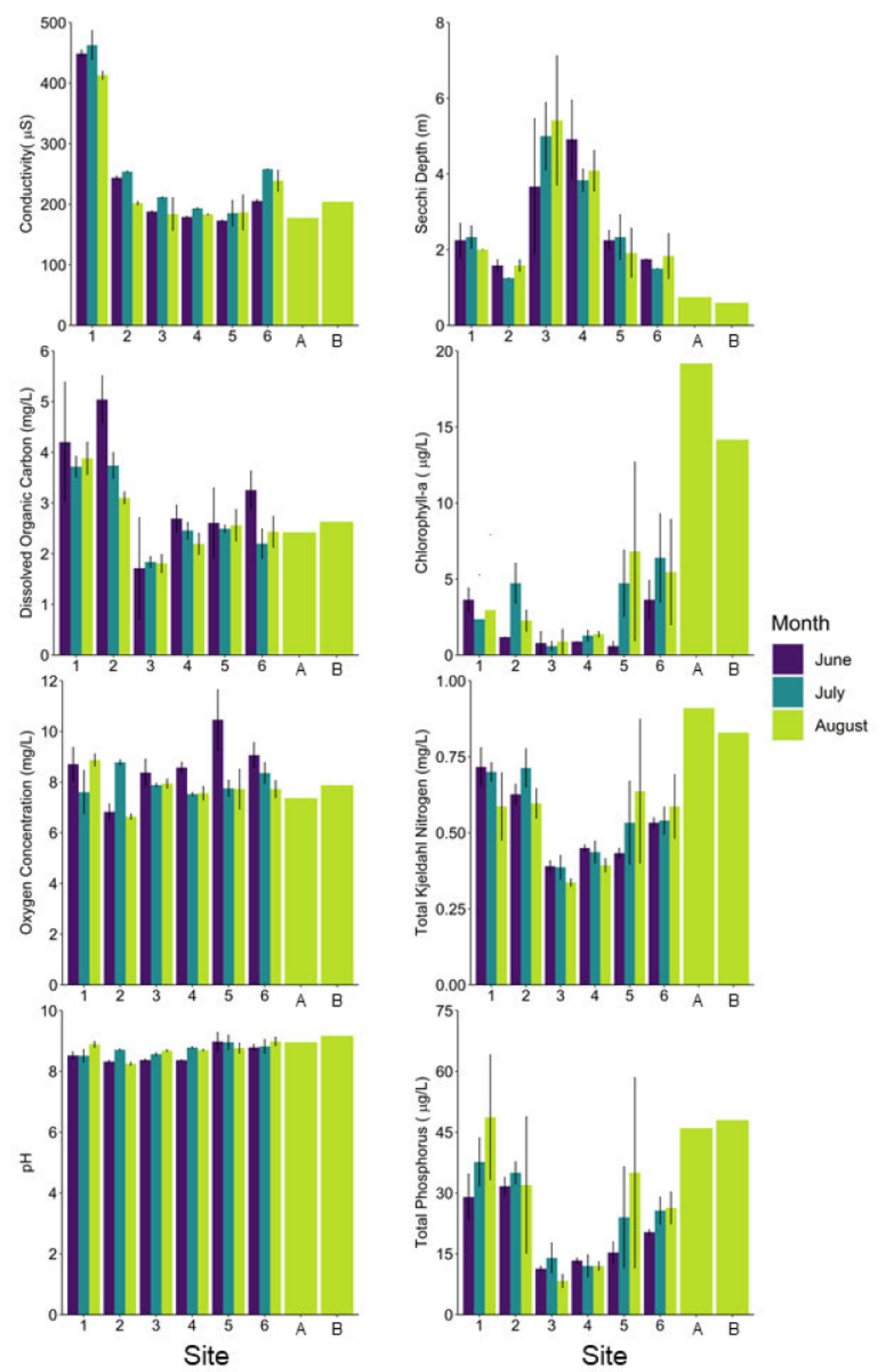

Figure 4-3. Physical and chemical characteristics of water quality (mean \pm s.d.) collected at monthly (1 - 6) and grab (A, B) sample sites from June to August 2019. 
The total number of PLUs per $\mathrm{mL}$ of water sample varied between site and month (Figure 4-1), and Bacillariophyceae, Chlorophyceae, Cryptophyceae, and Cyanophyceae composed a large proportion of the phytoplankton community at all sites (Figure 4-4). Site 1 had just over 1000 PLUs in June (28.2\% Chlorophyceae, 24.9\% Cryptophyceae, $20.9 \%$ Bacillariophyceae). The number of PLUs at Site 1 dropped to 334 in July (31.3\% Cryptophyceae and Cyanophyceae, and $23.9 \%$ Chlorophyceae), and remained stable into August at 335 PLUs (27.8\% Cyanophyceae, 20.4\% Cryptophyceae and Dinophyceae). The dominance of Dinophyceae is attributed to a large number of Ceratium hirundinella at Site 1 in August (58 PLUs; $17.3 \%$ of total PLUs) and was unique to this site.

At Site 2, 553 PLUs were counted among replicate samples in June (31.3\% Cryptophyceae, 29.7\% Chlorophyceae, 22.2\% Cyanophyceae; Figure 4-1, Figure 4-4). This number increased threefold by July to 1861 PLUs, with $72.5 \%$ of the PLUs being Bacillariophyceae and $65.1 \%$ of the total PLUs belonging to the genus Aulacoseira. In August, PLUs decreased by about one half to 971 PLUs, and the phytoplankton community shifted to $47.0 \%$ Cryptophyceae and $20.7 \%$ Bacillariophyceae.

Site 3 had only 110 PLUs in June (37.3\% Cyanophyceae, 24.5\% Chlorophyceae, and 21.8\% Bacillariophyceae; Figure 4-1, Figure 4-4). The PLUs at Site 3 increased dramatically in July to 1443 PLUs, of which $84.1 \%$ were filamentous Cyanophyceae. The PLUs remained stable (1501 PLUs) with in August and filamentous Cyanophyceae remained dominant $(76.6 \%)$.

There were 400 PLUs counted at Site 4 in June, which increased threefold to 1191 PLUs in July, and 1179 PLUs in August (Figure 4-1). In June, phytoplankton community was split fairly evenly amongst Cryptophyceae (32.3\%), Chlorophyceae (30.3\%), and 
Cyanophyceae (25.8\%; Figure 4-4). As the season progressed, Cyanophyceae became more dominant (38.1\% in July and $58.5 \%$ in August) and Chlorophyceae made up much of the remaining community ( $37.4 \%$ in July and $21.1 \%$ in August).

In comparison, Site 5 contained only 324 PLUs in June, but this number increased dramatically to 2082 PLUs in July, then increased further to 3376 PLUs in August (Figure 4-1). In June, the phytoplankton community was comprised of Cryptophyceae (33.3\%), Chlorophyceae (30.2\%), and Cyanophyceae (23.1\%; Figure 4-4). Similar to Site 4 , the community at Site 5 became dominated by Cyanophyceae and Chlorophyceae in July (56.2\% and $22.3 \%)$ and August (34.8\% and $37.9 \%)$.

Of the 846 PLUs counted at Site 6 in June, $35.0 \%$ were Cryptophyceae, $28.6 \%$ were Chlorophyceae, and 25.9\% were Cyanophyceae (Figure 4-1, Figure 4-4). The number of PLUs increased over time to 1877 PLUs in July and 2641 PLUs in August. In July, the phytoplankton community shifted slightly towards dominance by Cryptophyceae (37.9\%) and Cyanophyceae (28.2\%). However, the community was completely dominated by Cyanophyceae in August (71.8\%), the majority of which was colonies of Microcystis spp. (1266 PLUs).

Finally, grab-samples taken in August at the Lower Brewers (A) and Kingston Mills (B) lock stations contained 1416 and 8814 PLUs, respectively (Figure 4-1, Figure 4-4). Phytoplankton communities are both sites were dominated by filamentous Cyanophyceae, (66.9\% at Site A and $95.1 \%$ at Site B). 

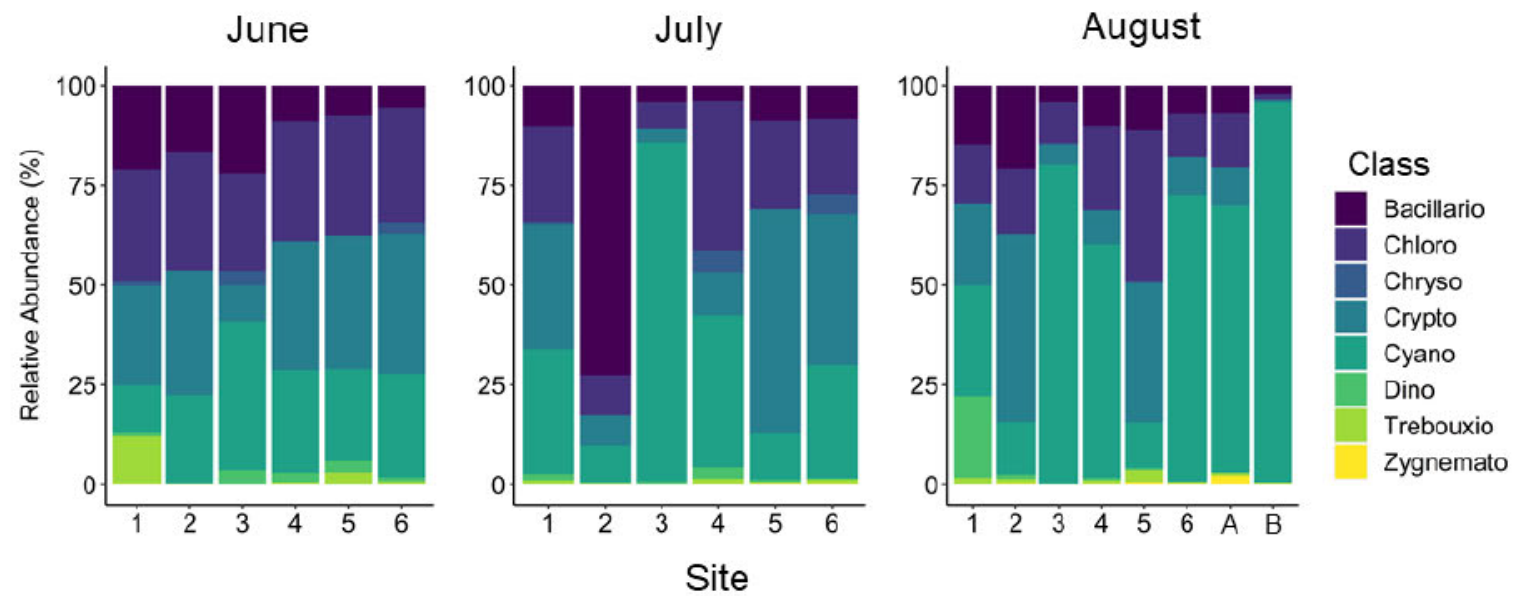

Figure 4-4. Relative abundance (\%) of each of the eight key classes of phytoplankton at monthly $(1-6)$ and grab (A, B) sample sites between June and August 2019.

Concentrations of TP generally coincided with the number of PLUs in all months, except at sites 1,2, and A where TP concentrations were high compared to the number of PLUs (Figure 4-5; top row). Oddly, TP concentrations increased over the summer at Site 1, while PLU counts declined. Like TP, the concentration of TKN generally coincided with the number of PLUs at all sites, except at sites 1, 2, and A (Figure 4-5; middle row). Overall, the recreational sites 3 and 4 had lower concentrations of TKN, while the urban and agricultural sites had somewhat higher concentrations. The concentration of chlorophyll-a corresponds well with the total number of PLUs at sites in all months (Figure 4-5; bottom row). However, in August, the chlorophyll-a concentration at Site A was very high compared to the number of PLUs counted. 


\section{June \\ July \\ August}
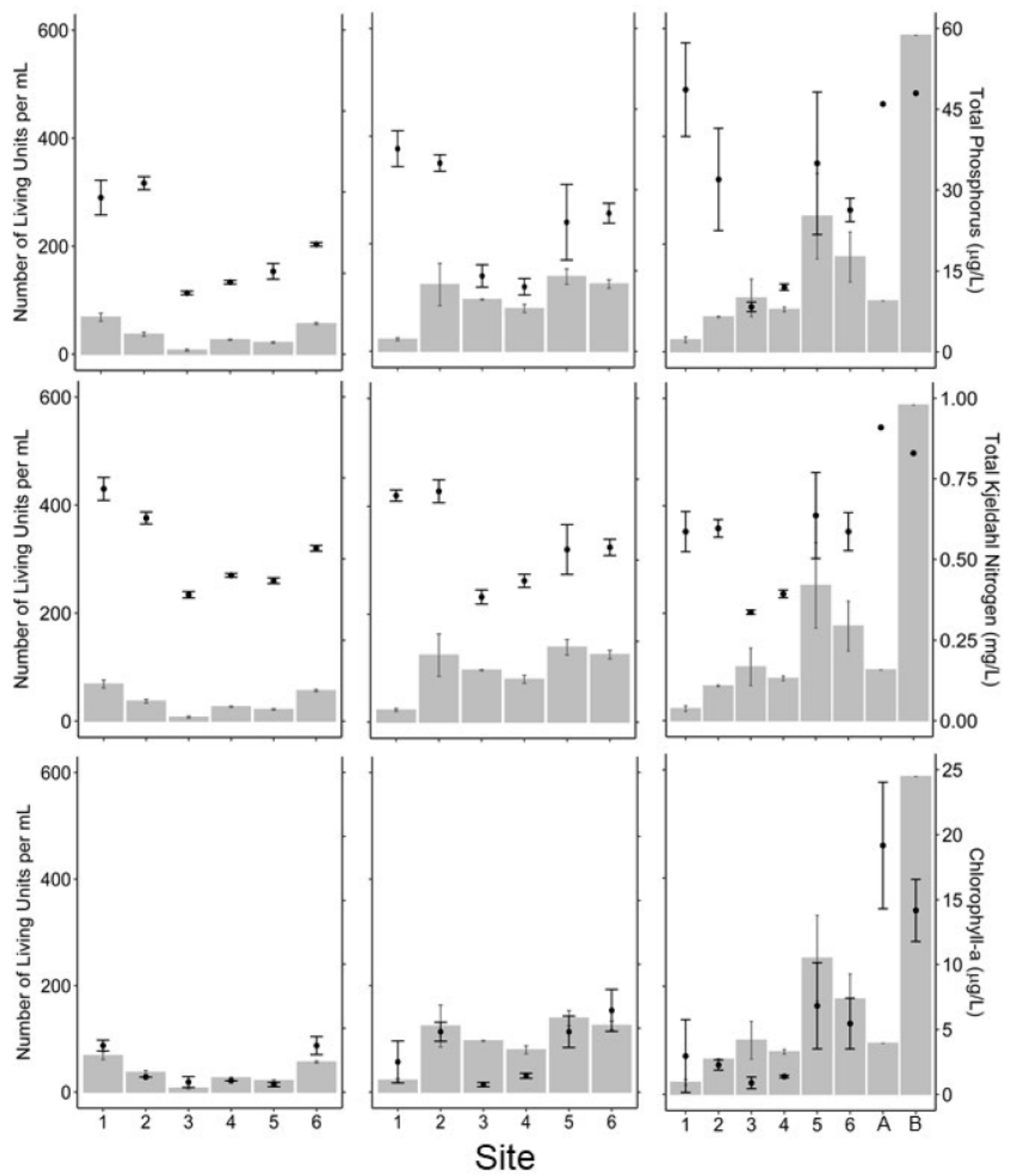

Figure 4-5. A comparison of the average number of phytoplankton living units per $\mathrm{mL}$ (grey bars; \pm s.d.) and average concentrations (black points; \pm s.d.) of total phosphorus ( $\mu \mathrm{g} / \mathrm{L}$; top row), total Kjeldahl nitrogen $(\mathrm{mg} / \mathrm{L}$; middle row), and chlorophyll-a $(\mu \mathrm{g} / \mathrm{L}$; bottom row) in monthly $(1-6)$ and grab (A, B) samples between June and August 2019. 
The broken-stick model indicated that PCA axes 1 through 4 were statistically significant, explaining $21.94 \%, 15.16 \%, 12.29 \%$, and $10.19 \%$ of the variance in the dataset, respectively. Along PCA axes 1, three groups of unicellular Cryptophyceae (Other, Cryptomonas reflexa, and Plagioselmis spp.) were scored lowest (-0.44, -0.28 , and -0.25) while two groups of filamentous Cyanophyceae (Cylinder, Filament) scored highest $(0.50,0.43)$. Along PCA axes 2 , four groups of unicellular and colonial phytoplankton (Cyanophyceae: Microcystis spp., Cryptophyceae: Other, Chlorophyceae: Sphaerocystis spp., and Cyanophyceae: Aphanothece spp.) were scored lowest (-0.41, $0.28,-0.27$, and -0.23 ) while two groups of unicellular Cryptophyceae (Cryptomonas reflexa and Plagioselmis spp.) scored highest $(0.27,0.23)$. With respect to site scores, Site 5A (-0.31) and 5C (-0.36) in July scored lowest along PCA axes 1, while Site 3A in June (0.72), Site 3C in August (0.64), Site A (0.59) and Site 3A-C in July $(0.57,0.55$, $0.57)$ scored highest. Along PCA axes 2 , Site $2 \mathrm{~A}$ and B in June $(0.45,0.56)$ scored highest and Site $6 \mathrm{~B}$ and $\mathrm{C}$ in August $(-0.71,-0.52)$ and Site $5 \mathrm{~B}$ and $\mathrm{C}(-0.48,-0.46)$ in August scored lowest.

The result of the PCA plot using axes 1 and 2 shows that samples collected in June are grouped in the upper left quadrant, samples collected in July are grouped in the lower left quadrant, and samples collected in August are grouped in the lower right quadrant (Figure 4-6A). This monthly transition from the upper left quadrant to the lower right quadrant coincides with shifts in phytoplankton community composition from cryptophytes and single-celled chlorophytes to colonial and filamentous cyanophytes (Figure 4-6B; abbreviated species names in Table 7-1). Based off the correlation matrix of environmental variables and PCA axes (Table 4-2), DOC, TKN, and TP were loaded 
highest along axis 1, distance from the Ottawa River was loaded highest on both axis 2 and 3, and TKN was loaded highest along axis 4 .
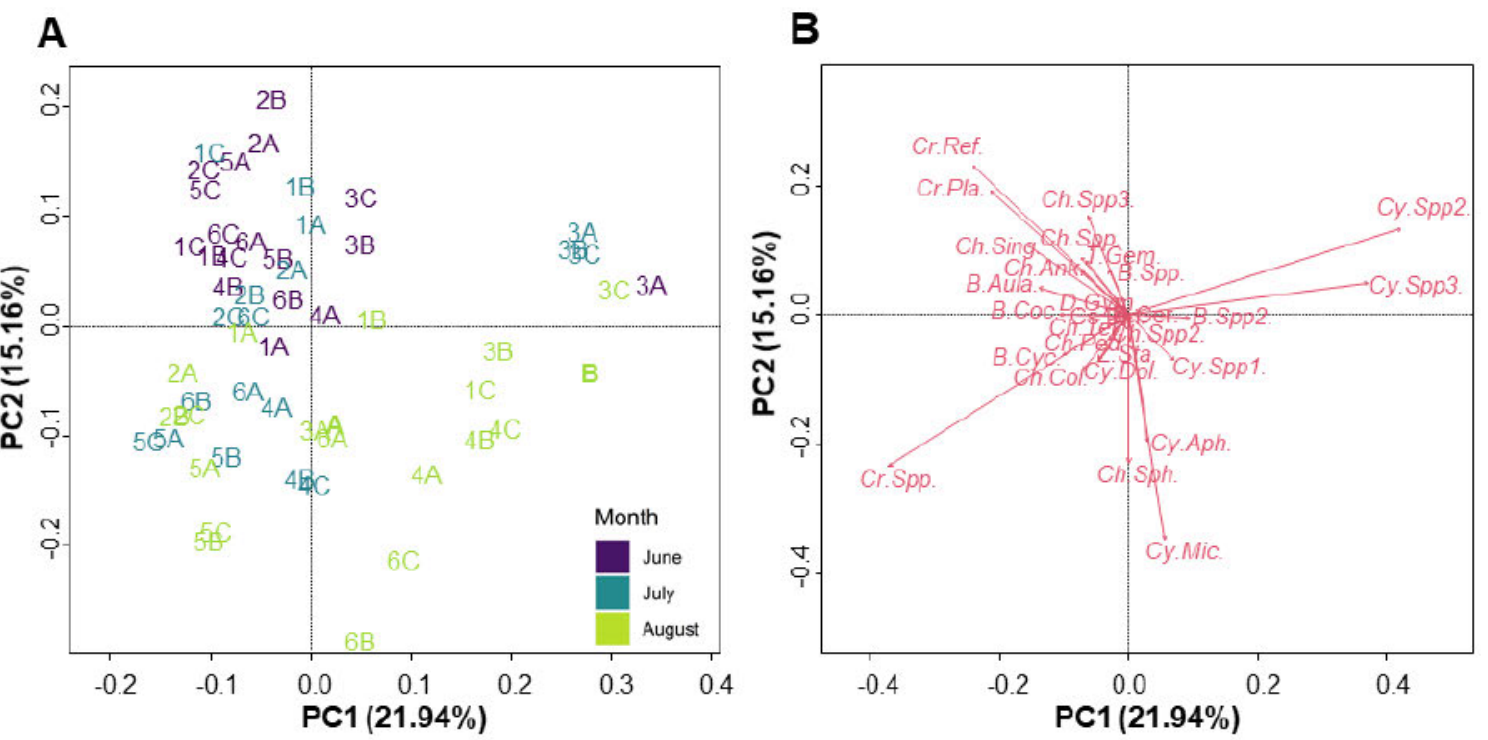

Figure 4-6. Principal component analysis (PCA) of the most common phytoplankton groups by sample site. Sites are presented by month $($ purple $=$ June, blue $=$ July, green $=$ August) in panel A using PCA scaling 1, and phytoplankton groups are presented in panel B using PCA scaling 2. PCA axis 1 represents $21.94 \%$ of the variance explained, while PCA axis 2 represented $15.16 \%$ of the variance explained. Abbreviated and full phytoplankton sub-group names are provided in Table 7-1. 


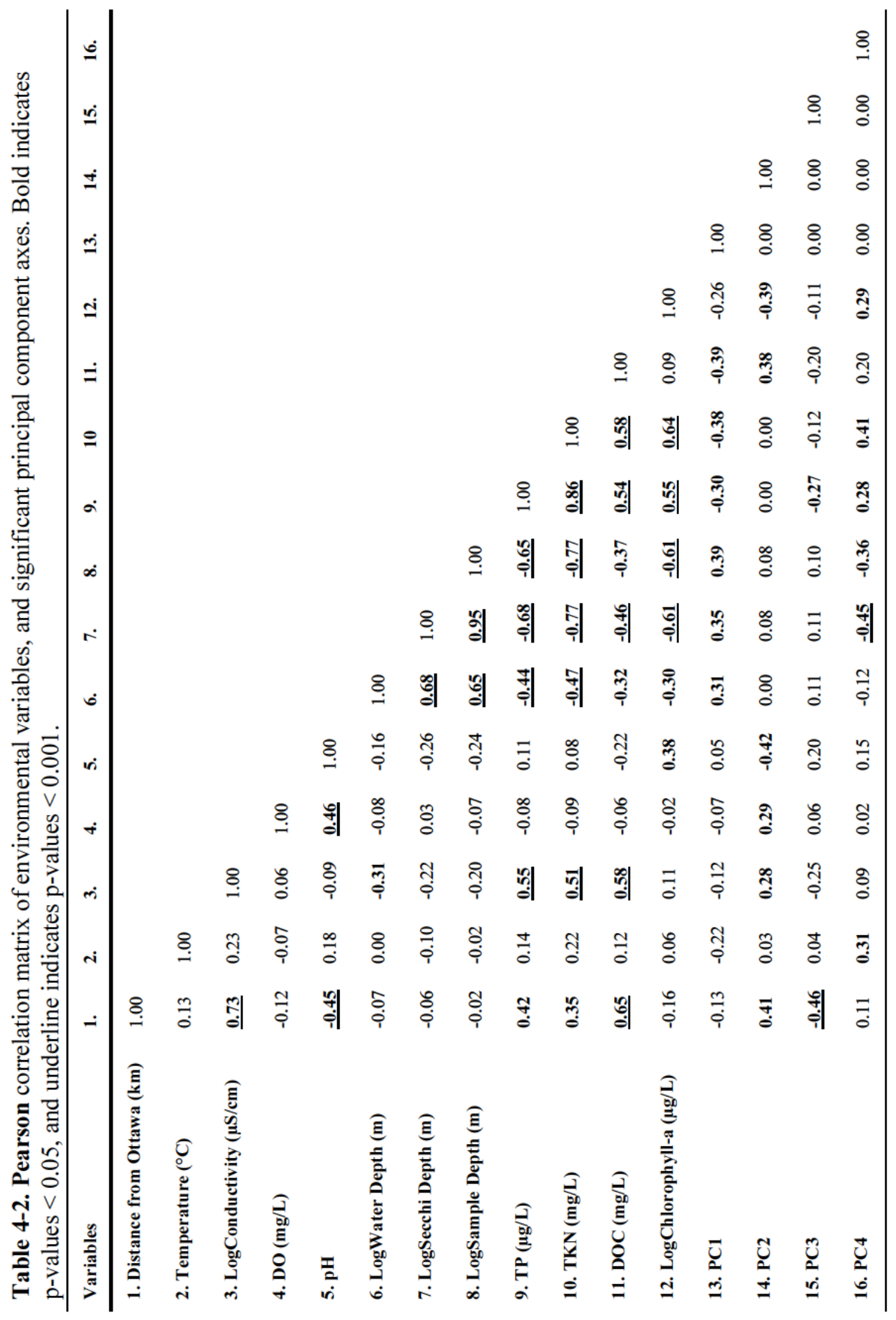


The variance inflation factor (VIF) of each environmental variable was examined to determine how much the variance explained by a regression coefficient is inflated due to the presence of other explanatory variables. The VIF of each explanatory variable should remain below 10 , and if many VIFs are greater than 20 , collinearity is likely to exist, and further explanatory variables should be removed from the RDA model. Here, the VIFs ranged from 1.19 (Temperature) to 2.00 (TP), therefore no further explanatory environmental variables were removed. Correlations determined that logSecchi depth, logSample depth, and TKN should be excluded in further RDA analyses as they were highly correlated with at least one other environmental variable $(\mathrm{R}>0.65$ or $\mathrm{R}<-0.65$;

\section{Table 4-2).}

The backward selection model indicated that temperature $(\mathrm{p}=0.005)$, $\log$ Conductivity $(\mathrm{p}=0.015)$, dissolved oxygen $(\mathrm{p}=0.005), \mathrm{pH}(\mathrm{p}=0.005), \mathrm{TP}(\mathrm{p}=$ $0.020)$, and DOC $(\mathrm{p}=0.010)$ were significant drivers of phytoplankton community assemblage (model $\mathrm{p}=0.001)$, and only $\log$ Water depth $(0.315)$ was not a significant driver. Therefore, temperature, logConductivity, dissolved oxygen, $\mathrm{pH}, \mathrm{TP}$, and DOC were included in the final RDA model. In this model, RDA axes 1 and 2 explained $12.54 \%$ and $6.61 \%$ of the variance in the dataset, respectively $(\mathrm{p}=0.001)$. An RDA using only TP as an explanatory variable showed that TP alone explains $4.73 \%$ of the variance in the dataset $(\mathrm{p}=0.002)$.

Using temperature, logConductivity, dissolved oxygen, $\mathrm{pH}, \mathrm{TP}$, and $\mathrm{DOC}$ to represent the physical and chemical aspects of the environment, distance from Ottawa to represent spatial controls, and month to represent the temporal controls, variance partitioning was used to explain variance in phytoplankton community composition 
(Figure 4-7). Together, the environmental, spatial, and temporal factors included in this analysis account for approximately $24 \%$ of the variation in the phytoplankton community composition of the Rideau Canal. The physical and chemical environment alone explains $8.77 \%$ of the variation in the dataset $(\mathrm{p}=0.001)$, while solely spatial and temporal controls explain $0.94 \%(\mathrm{p}=0.001)$ and $3.20 \%(\mathrm{p}=0.001)$, respectively. The temporallystructured environment explains $5.92 \%$ of the variance in phytoplankton community composition, while the spatially-structured environment explains $4.19 \%$ of the environment. Spatiotemporal controls account for only $1.22 \%$ of the variation of the phytoplankton community. Finally, none of the variance in phytoplankton community composition was explained by a spatiotemporally-structured environment. 


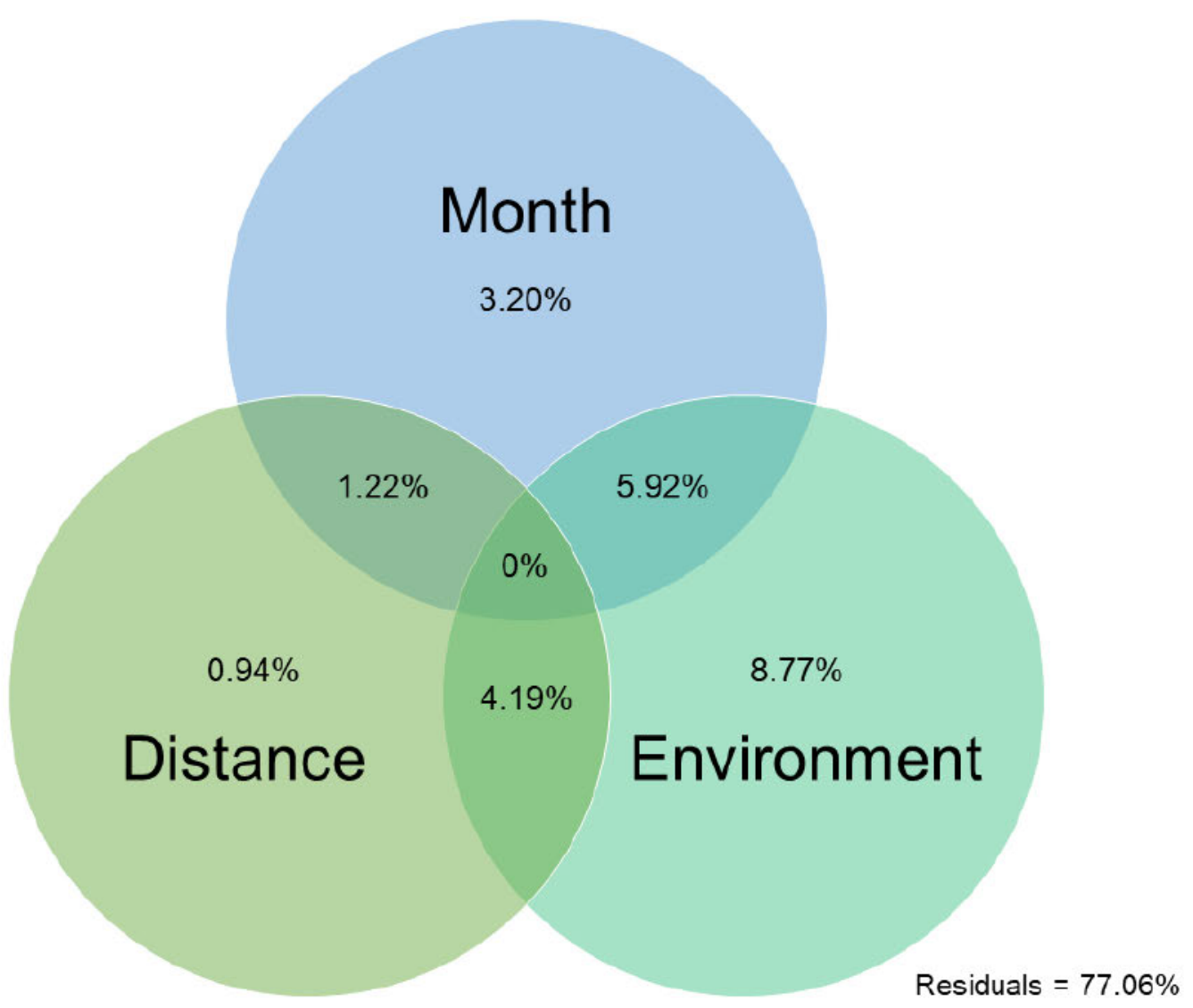

Figure 4-7. Variance partitioning of the most common phytoplankton groups at each site using redundancy and partial redundancy analyses. The proportion of variance explained by environmental variables (temperature, logConductivity, oxygen concentration, $\mathrm{pH}$, total phosphorus, and dissolved organic carbon), distance of sample site from Ottawa, month in which the sample was collected, and residual variance are presented as percentages (\%). All testable proportions are significant with p-values $<0.02$.

\subsection{DISCUSSION}

Generally, phytoplankton biomass in the Rideau Canal was higher in areas with higher concentrations of TP and TKN. However, the unnatural flow regime in the manmade portion of the canal in Ottawa proper may have decoupled the relationship between nutrients and phytoplankton abundance. The phytoplankton community composition of the Rideau Canal is mainly structured by the chemical and physical environment. As observed in the Rideau River, the phytoplankton community in the Rideau Canal largely 
consists of Bacillariophyceae, Chlorophyceae, Cryptophyceae, and Cyanophyceae (Hamilton et al. 2011; Vidal et al. 2004). In 2019, blooms of the diatom Aulacoseira spp., filamentous cyanobacteria, and the dinophyte Ceratium hirundinella were observed. Temporal variation also plays a role in the formation of the phytoplankton community, albeit less so than environmental factors, with cyanobacteria often becoming the dominant taxon as the summer season progressed and nutrients conditions became favourable. Spatial controls had little impact on phytoplankton community composition, and spatially-structured environment explained only a modest portion of the variation in phytoplankton community.

Watersheds with high proportions of agricultural and urban land often experience increased nutrient loading into surface waters from point and non-point sources than natural land (Carpenter et al. 1998; Puckett 1995). In urban areas, runoff and leachate from landfills, septic systems, and wastewater treatment plants are the major sources of nutrient inputs (Carey et al. 2013). Whereas in agricultural areas, runoff and leachate rich with phosphorus and nitrogen from fertilizers are the main nutrient sources to rivers (Withers and Lord 2002).

Almost all water samples had TP concentrations above the $10 \mu \mathrm{g} / \mathrm{L}$ maximum concentration recommended by Ontario's Ministry of the Environment (1979) to maintain the aesthetic value of lakes. The riverine Site 2 also had TP concentrations that surpassed the recommended TP concentration for rivers $(30 \mu \mathrm{g} / \mathrm{L})$ set by the Ministry of the Environment (1979) in all months. Both sites surrounded by agricultural land-use (sites 2 and 5) had moderate TP concentrations, whereas TP concentrations at urban sites (1 and 6) were relatively higher. Concentrations of TKN were also comparable at 
agricultural and urban sites. Sites surrounded by recreational land-use (sites 3 and 4) had lower nutrient (TP and TKN) concentrations, lower chlorophyll-a concentrations, and greater Secchi depths compared to agricultural and urban sites.

In addition, the noticeable increase in conductivity, a measure of salinity, in the man-made section of the Rideau Canal in Ottawa can be attributed to the high proportion of impervious surfaces surrounding the canal. Increased salinity in urban areas is a known impact of impervious surfaces which facilitate runoff with high concentrations of road salts, nutrients and other contaminants (Paul and Meyer 2001).

Harmful algal blooms (HABs) are known to be caused by increased concentrations of phosphorus and nitrogen (Huisman et al. 2018; Paerl et al. 2011, 2001). However, nitrogen limitation in the presence of sufficient concentrations of phosphorus can also result in HABs dominated by taxa of cyanobacteria that fix atmospheric nitrogen (Schindler et al. 2008). Initially, this was thought to be the reason for the abundance of cyanobacteria at Site 3 in July and August despite relatively low nutrient concentrations. However, the dominant filamentous cyanobacteria at Site 3 did not have visible heterocysts and therefore may not have been a taxon capable of nitrogen-fixation.

The high concentration of TP at Site 1 is also worth noting since high TP concentrations are associated with the formation of HABs. However, phytoplankton abundance (PLUs/mL) was surprisingly low at this site in July and August. The altered flow regime caused by the high density of locks in the man-made portion of the Rideau Canal in Ottawa (Site 1) may decouple the nutrient-phytoplankton relationship as operation of the locks flushes out the canal, and the unfavourable physical conditions affect phytoplankton community more than the favourable nutrient levels (Reynolds and 
Descy 1996). High flushing rates are known to prevent the formation of algal blooms (Maier et al. 2004; Paerl et al. 2011), and the decoupling of the nutrient-phytoplankton relationship has also been noted in Alpine rivers with similarly variable flow regime (Salmaso and Braioni 2008; Salmaso and Zignin 2010).

The abundance of cyanobacteria at Site 3 in July and August was also comparable to that of Site 5, despite large differences in nutrient concentrations. At Site 3, the dominant cyanobacteria were filamentous, whereas Site 5 had a slightly larger proportion of unicellular colonial cyanobacteria like Aphanothece spp. and Microcystis spp. in August. The differences in the form of dominant cyanobacteria (filaments versus unicellular colonies) may be the result of differences in the physical environment. Site 3 is a large, deep lacustrine environment (Big Rideau Lake, maximum depth sampled $=54$ m) whereas Site 5 is a much shallower connecting area between Whitefish Lake and Cranberry Lake (maximum depth sampled $=5.5 \mathrm{~m}$ ). Water temperatures at Site 5 were somewhat higher than at Site 3. Since Microcystis spp. is known to prefer warmer water temperatures (Dokulil and Teubner 2000; Giblin and Gerrish 2020). This may be one reason for the higher abundance of Microcystis spp. at Site 5.

Phytoplankton abundance was generally lower at the lacustrine sites 3 and 4 than at the riverine sites 2 and 6 . This is the opposite of the trend described by Søballe and Kimmel (1987) where phytoplankton abundance was twice as high in lakes as in rivers regardless of lower phosphorus concentrations in lakes. However, the lakes and rivers that comprise the Rideau Canal have much lower TP concentrations (lakes: $11.8 \pm 2.5$ $\mu \mathrm{g} / \mathrm{L}$; rivers: $28.5 \pm 7.8 \mu \mathrm{g} / \mathrm{L})$ than those in the study by Søballe and Kimmel (1987; lakes: $105 \pm 18 \mu \mathrm{g} / \mathrm{L}$; rivers: $153 \pm 16 \mu \mathrm{g} / \mathrm{L}$ ), which may be a reason for the lack of 
agreement between these studies on how phytoplankton communities differ in lacustrine and riverine ecosystems.

Phytoplankton biomass and abundance also corresponded with one another, except for at Site A where phytoplankton biomass was much higher than expected from PLU counts. Of the $66.9 \%$ of the phytoplankton community that was Cyanophyceae, $31 \%$ was identified as Dolichospermum spp., a genus that is relatively large in size compared to other phytoplankton. For example, assuming a single, randomly selected PLU in the group Dolichospermum spp. is generally spherical, the volume of one cell of the PLU would be $150 \mu \mathrm{m}^{3}$ (Hillebrand et al. 1999). As Dolichospermum spp. occur in chains of multiple cells, and this random PLU is a chain of 10 cells, then the biovolume of the PLU would be $1500 \mu^{3}$. In comparison, Cryptophyceae occur as individual cells and are not colonial. So, the biovolume of a single, randomly selected PLU in this group may only be $85 \mu \mathrm{m}^{3}$ (the shape of a Cryptophyceae cell can be approximated as a cone plus half sphere; Hillebrand et al. 1999). Taking this into consideration, we see that the biovolume of the two PLUs are very different and therefore the chlorophyll-a content of the two PLUs would also be different. Since the phytoplankton community at Site A is largely composed of Dolichospermum spp., it should not be expected that the PLU abundance and chlorophyll-a concentration correspond with one another as they do at sites composed of smaller phytoplankton groups. It has been discussed before that chlorophylla estimates of algal biomass should be considered with care (e.g., Nicholls and Dillon 1978; Søndergaard et al. 2011), and other approaches for more accurate measurements of phytoplankton biomass have been proposed (Kasprzak et al. 2008). 
The use of the FlowCam as a method for examining phytoplankton community composition in the Rideau Canal is also worth noting as it is a novel component of this study. The FlowCam uses flow cytometry and microscopy to quickly process large quantities of water, capturing an image of each particle that passes by the lens. While the FlowCam is very efficient in that regard, the time required to manually identify and classify the large number of images post-processing can be a disadvantage. However, as FlowCam technology becomes more advanced and the user is able to create more effective classification filters, this process should become less reliant on the user. In addition, the relatively low magnification of the FlowCam (up to 200X, 100X used in this study) restricts the degree of specificity to which the user can identify phytoplankton. This is important as the identification of phytoplankton to a lower taxonomic level leads to more detailed insights about environmental conditions (Cupertino et al. 2019; Schindler 1990). As a result, it has been recommended that more traditional microscopy techniques continue to be used in conjunction with the FlowCam, to ensure particles are accurately identified to lower taxonomic levels (Graham et al. 2018; Hrycik et al. 2019; Tarrant et al. 2009).

Temporal changes explain a modest amount of the variation in phytoplankton community composition in the Rideau Canal. Seasonally, there was a loss of taxa abundance at most sites $(2-6)$ as phytoplankton communities shifted towards dominance of only one or two taxa. In general, phytoplankton community composition in the Rideau Canal transformed from a cryptophyte- and single-celled chlorophyte-dominated system in June, to a system dominated by colonial and filamentous cyanophytes and chlorophytes in August. This is in agreement with the PEG-model of phytoplankton 
seasonal succession where small, edible Cryptophyceae dominate early in the season, with larger filamentous and colonial phytoplankton forming later in the season (Sommer et al. 1986). However, this was not the case at Site 2 which was dominated by cryptophytes in August, following a bloom of Aulacoseira spp in July. The dominance of this taxa, and diatoms in general, are common in riverine ecosystems with moderate flow rates such as Site 2 (Hötzel and Croome 1996).

The seasonal dominance of Ceratium hirundinella at Site 1 in August is also interesting. The high number of $C$. hirundinella at Site 1 was observed in Dow's Lake, a small man-made lake in Ottawa that branches off the main canal. This species is motile and succeeds in stratified waters where it can accumulate at depths with specific light, nutrient, and oxygen conditions (Harris et al. 1979). C. hirundinella also generally appear later in the season (August to October), as they did in this study, and are generally unaffected by turbulence as their motility allows them to reposition themselves in the water column (Heaney 1976). Furthermore, C. hirundinella is often outcompeted by cyanobacteria (Dottne-Lindgren and Ekbohm 1975; Vance 1965). When

C. hirundinella is not superseded by cyanobacteria, dangerous blooms of $C$. hirundinella may form and are known to cause fish kills (Nicholls et al. 1980).

In the Rideau Canal, phytoplankton community composition is not explained well by purely spatial controls. As discussed by Soininen and Weckström (2009) and Bennett et al. (2010), spatial controls explain algal community variation best at inter-continental scale while the environment plays a stronger role at regional scale. It should also be mentioned that the high connectivity of canals is known to shape phytoplankton communities, as the increased connectivity homogenizes phytoplankton communities, 
thus minimizing spatial differences and decreasing beta diversity between sites within the canal (Kelly and Hassall 2018). Therefore, it seems that phytoplankton community composition at regional scale, and in highly connected, artificial waterways such as the Rideau Canal, conforms to the Baas Becking (1934) hypothesis that "everything is everywhere, but the environment selects".

Even still, improving our understanding of the drivers of phytoplankton abundance, biomass, and community composition can be helpful in selecting appropriate management measures to mitigate biodiversity loss in aquatic ecosystems (Chalar 2009). Since phytoplankton community composition is largely driven by the physical and chemical environment in the Rideau Canal, management efforts should be focussed on environmental drivers of HABs. Maintaining adequate water flows and reducing nutrient inputs into the waterway are two ways to reduce the prevalence of cyanobacterial blooms as the summer progresses (Maier et al. 2004; Paerl et al. 2011), and ensure good water quality is maintained in the waterway to support recreation and tourism. 


\section{CONCLUSIONS}

This thesis explored the impacts of human activities and other drivers on periphyton and phytoplankton in a regulated waterway. The Rideau Canal is a heritage waterway of significant cultural, social, ecological, and economic importance that relies on good water quality to provide these benefits to Canadians. However, water quality in the Rideau Canal has become of concern to residents and users of the waterway in recent years (Mistry et al. 2021). The main objective of this thesis was to examine and quantify the environmental (biological, chemical, and physical), temporal, and spatial drivers of algal biomass and community composition in the Rideau Canal.

In Chapter 3, the biological and chemical changes to periphyton biomass and water chemistry in the Rideau River since 1995 were examined. After 24 years, the midstream section of the Rideau River showed a reduction in the concentration of total phosphorus and an increase in chloride concentration. Concentrations of nitrogen have also slightly declined. These changes in water chemistry are likely attributed to the urbanization within the Lower Rideau River watershed. Meanwhile, periphyton biomass became more uniform along the length of the river in 2019, which differs from the positive relationship it showed with distance in 1995. Furthermore, zebra mussel populations have increased in this stretch of the river, which may have implications for algae in this area. Since periphyton plays a key role in aquatic food webs (Vadeboncoeur and Power 2017), it is necessary that changes in biomass are monitored in response to a changing environment.

In Chapter 4, a FlowCam was used to examine and quantify environmental (chemical and physical), temporal, and spatial drivers of phytoplankton biomass, abundance, and community composition in the Rideau Canal. Generally, phytoplankton biomass is highest at sites with higher concentrations of total phosphorus and total 
Kjeldahl nitrogen and is associated with phytoplankton abundance (counts). An exception to this generalization is noted at one site that experienced a high abundance of Dolichospermum spp. This taxon is much larger in size compared to other commonly occurring taxa in the waterway and therefore resulted in higher phytoplankton biomass. The chemical and physical environment explains a greater proportion of the variation in phytoplankton biomass than temporal and spatial controls do. Thus, an emphasis should be placed on managing human activities that alter the chemical and physical environment to ensure good water quality is maintained in the Rideau Canal.

The findings of this thesis stress the importance of investigating the numerous impacts of human activity on freshwater ecosystems. The Rideau Canal is a complex waterway where environmental and human impacts are intertwined and reflected in the biodiversity of the ecosystem. This thesis solidifies the previously-identified relationship between nutrients and water quality (Carpenter et al. 1998; Schindler 2006), and maintains the importance of this relationship in a highly regulated waterway with a variable flow regime and invasive species. Together, the cumulative effects of salinisation, land-use change and climate warming, put aquatic ecosystems globally at risk of becoming degraded at an alarming rate (Sala et al. 2000; WWF 2020). While freshwater ecosystems can be resilient to environmental change, they can also be altered beyond their ecological tipping point and unique aspects of the ecosystem can be lost (Scheffer 1990; Scheffer et al. 2012, 1993). Therefore, it is essential that efforts are made to quantify and disentangle the impacts of multiple stressors on ecosystems to identify management actions for mitigation and prevention. 
Moving forward, long-term monitoring of systems such as the Rideau Canal must be continued to recognize disturbances and trends as they happen. For example, the recent invasions of round goby and spiny water flea in the Rideau Canal (EDDMapS 2021) should be monitored closely to determine if, and when, these species become established. In the meantime, management efforts can be made to mitigate their further expansion into surrounding areas and to monitor existing populations of invasive species such as the zebra mussel.

Future research focussed on quantifying the impacts of land-use change on aquatic ecosystems can be used to support them as urban sprawl intensifies, and natural ecosystems are lost. Paleolimnological analyses of eutrophic lakes along the Rideau Canal (e.g., Cranberry Lake, Dog Lake, Sand Lake; CRCA 2017) may be used to assess their historical trophic status prior to the construction of the canal. This type of analysis would be useful for determining if the lakes in the area are naturally eutrophic or if human activity is the driver. Paleolimnological investigations can also help determine when approximately the trophic status of these lakes shifted. Identifying current major sources of phosphorus and nitrogen into the Rideau Canal can help reduce nutrient loading and determining if increased regulation of flow rates in the canal can reduce the prevalence of harmful algal blooms, may also be useful. 


\section{REFERENCES}

Abram, N.J., McGregor, H. V., Tierney, J.E., Evans, M.N., McKay, N.P., Kaufman, D.S., Thirumalai, K., Martrat, B., Goosse, H., Phipps, S.J., Steig, E.J., Kilbourne, K.H., Saenger, C.P., Zinke, J., Leduc, G., Addison, J.A., Mortyn, P.G., Seidenkrantz, M.S., Sicre, M.A., Selvaraj, K., Filipsson, H.L., Neukom, R., Gergis, J., Curran, M.A.J., Von Gunten, L., 2016. Early onset of industrial-era warming across the oceans and continents. Nature 536, 411-418.

Adrian, R., Deneke, R., Mischke, U., Stellmacher, R., Lederer, P., 1995. A long-term study of the Heiligensee (1975-1992). Evidence for effects of climatic change on the dynamics of eutrophied lake ecosystems. Archiv fur Hydrobiologie 133, 315337.

Aiken, S.G., Newroth, P.R., Wile, I., 1979. The biology of Canadian weeds. 34. Myriophyllum spicatum L. Canadian Journal of Plant Science 59, 201-215.

Alexander, R.B., Smith, R.A., 2006. Trends in the nutrient enrichment of U.S. rivers during the late 20th century and their relation to changes in probable stream trophic conditions. Limnology and Oceanography 51, 639-654.

Allan, J.D., 2004. Landscapes and riverscapes: The influence of land use on stream ecosystems. Annual Review of Ecology, Evolution, and Systematics 35, 257-284.

Allan, J.D., Castillo, M.M., Capps, K.A., 2021. Stream Ecology: Structure and function of running waters, Third. ed. Cham, Switzerland.

Anderson, D.M., Glibert, P.M., Burkholder, J.M., Gilbert, P.M., Burkholder, J.M., 2002. Harmful algal blooms and eutrophication: Nutrient sources, composition, and consequences. Estuaries 25, 704-726.

Baas Becking, L.G.M., 1934. Geobiologie of inleiding tot de milieukunde. W.P. Van Stockum \& Zoon (in Dutch), The Hague, Netherlands.

Ballinger, D., 1994. Managing the Rideau Canal: Issues of Conservation and Tourism. International Council on Monuments and Sites Canada Bulletin 3.

Barnhisel, D.R., Harvey, H.A., 1995. Size-specific fish avoidance of the spined crustacean Bythotrephes: field support for laboratory predictions. Canadian Journal of Fisheries and Aquatic Sciences 52, 768-775.

Barton, D.R., Johnson, R.A., Campbell, L., Petruniak, J., Patterson, M., 2005. Effects of round gobies (Neogobius melanostomus) on dreissenid mussels and other invertebrates in Eastern Lake Erie, 2002-2004. Journal of Great Lakes Research $31,252-261$. 
Bastviken, D.T.E., Caraco, N.F., Cole, J.J., 1998. Experimental measurements of zebra mussel (Dreissena polymorpha) impacts on phytoplankton community composition. Freshwater Biology 39, 375-386.

Basu, B.K., Pick, F.R., 1995. Longitudinal and seasonal development of planktonic chlorophyll a in the Rideau River, Ontario. Canadian Journal of Fisheries and Aquatic Sciences 52, 804-815.

Basu, B.K., Pick, F.R., 1996. Factors regulating phytoplankton and zooplankton biomass in temperate rivers. Limnology and Oceanography 41, 1572-1577.

Basu, B.K., Pick, F.R., 1997. Phytoplankton and zooplankton development in a lowland, temperate river. Journal of Plankton Research 19, 237-253.

Bazinet, N.L., Gilbert, B.M., Wallace, A.M., 2010. A comparison of urbanization effects on stream benthic macroinvertebrates and water chemistry in an urban and an urbanizing basin in Southern Ontario, Canada. Water Quality Research Journal of Canada 45, 327-341.

Bennett, J.R., Cumming, B.F., Ginn, B.K., Smol, J.P., 2010. Broad-scale environmental response and niche conservatism in lacustrine diatom communities. Global Ecology and Biogeography 19, 724-732.

Benson, A.J., 2014. Chronological history of zebra and quagga mussels (Dreissenidae) in North America, 1988-2010. In: Nalepa, T.F., Schloesser, D.W. (Eds.), Quagga and Zebra Mussels: Biology, Impacts, and Control. CRC Press, Boca Raton, FL, pp. 931.

Bergman, J.N., Beaudoin, C., Mistry, I., Turcotte, A., Vis, C., Minelga, V., Neigel, K.L., Lin, H.-Y., Bennett, J.R., Young, N., Rennie, C., Trottier, L.L., Abrams, A.E.I., Beaupre, P., Glassman, D., Blouin-Demers, G., Garant, D., Donaldson, L., Vermaire, J., Smol, J.P., Cooke, S.J., 2021. Historical, contemporary, and future perspectives on a coupled social-ecological system in a changing world: Canada's historic Rideau Canal. Environmental Reviews.

Biggs, B.J.F., Close, M.E., 1989. Periphyton biomass dynamics in gravel bed rivers: the relative effects of flows and nutrients. Freshwater Biology 22, 209-231.

Biggs, B.J.F., Goring, D.G., Nikora, V.I., 1998a. Subsidy and stress responses of stream periphyton to gradients in water velocity as a function of community growth form. Journal of Phycology 34, 598-607.

Biggs, B.J.F., Stevenson, R.J., Lowe, R.L., 1998b. A habitat matrix conceptual model for stream periphyton. Archiv fur Hydrobiologie 143, 21-56.

Biggs, B.J.F., Stokseth, S., 1996. Hydraulic habitat suitability for periphyton in rivers. Regulated Rivers: Research and Management 12, 251-261. 
Birks, H.J.B., 2010. Numerical methods for the analysis of diatom assemblage data. In: Smol, J.P., Stoermer, E.F. (Eds.), The Diatoms: Applications for the Environmental and Earth Sciences. Cambridge University Press, Cambridge, UK.

Bobeldyk, A.M., Lamberti, G.A., 2008. A decade after invasion: Evaluating the continuing effects of rusty crayfish on a Michigan river. Journal of Great Lakes Research 34, 265-275.

Boehrer, B., Schultze, M., 2008. Stratification of lakes. Reviews of Geophysics 46, 1-27.

Bonada, N., Prat, N., Resh, V.H., Statzner, B., 2006. Developments in aquatic insect biomonitoring: A comparative analysis of recent approaches. Annual Review of Entomology 51, 495-523.

Braschi, L., Wilcott, L., (CBCL Limited), 2020. Climate projections for the National Capital Region: Executive Summary. Ottawa, Canada.

Brett, M.T., Kainz, M.J., Taipale, S.J., Seshana, H., 2009. Phytoplankton, not allochthonous carbon, sustains herbivorous zooplankton production. Proceedings of the National Academy of Sciences of the United States of America 106, $21197-$ 21201.

Brooks, B.W., Lazorchak, J.M., Howard, M.D.A., Johnson, M.-V.V. V., Morton, S.L., Perkins, D.A.K., Reavie, E.D., Scott, G.I., Smith, S.A., Steevens, J.A., 2016. Are harmful algal blooms becoming the greatest inland water quality threat to public health and aquatic ecosystems? Environmental Toxicology and Chemistry 35, 6-13.

Bubeck, R.C., Diment, W.H., Deck, B.L., Baldwin, A.L., Lipton, S.D., 1971. Runoff of deicing salt: Effect on Irondequoit Bay, Rochester, New York. Science 172, 11281131 .

Bunn, S.E., Arthington, A.H., 2002. Basic principles and ecological consequences of altered flow regimes for aquatic biodiversity. Environmental Management.

Burkholder, J.A.M., 2000. Eutrophication and Oligotrophication. In: Levin, S.A. (Ed.), Encyclopedia of Biodiversity. Academic Press, New York, NY.

Burnison, B.K., 1980. Modified Dimethyl Sulfoxide (DMSO) Extraction for Chlorophyll Analysis of Phytoplankton. Canadian Journal of Fisheries and Aquatic Sciences 37, 729-733.

Butler, R.W., 1980. The concept of a tourist area cycle of evolution: Implications for management of resources. Canadian Geographer 24, 5-12.

Canadian Council of Ministers of the Environment (CCME). 2011. Canadian water quality guidelines for the protection of aquatic life: Chloride. In: Canadian environmental quality guidelines, 1999, Canadian Council of Ministers of the Environment, Winnipeg. 
Canadian Heritage Rivers System, 2021. Rideau Waterway, Ontario. https://chrs.ca/en/rivers/rideau-waterway.

Cañedo-Argüelles, M., Kefford, B.J., Piscart, C., Prat, N., Schäfer, R.B., Schulz, C.J., 2013. Salinisation of rivers: An urgent ecological issue. Environmental Pollution $173,157-167$.

Cantonati, M., Lowe, R.L., 2014. Lake benthic algae: Toward an understanding of their ecology. Freshwater Science 33, 475-486.

Caraco, N.F., Cole, J.J., Raymond, P.A., Strayer, D.L., Pace, M.L., Findlay, S.E.G., Fischer, D.T., 1997. Zebra mussel invasion in a large, turbid river: Phytoplankton response to increased grazing. Ecology 78, 588-602.

Cardinale, B.J., Srivastava, D.S., Duffy, J.E., Wright, J.P., Downing, A.L., Sankaran, M., Jouseau, C., 2006. Effects of biodiversity on the functioning of trophic groups and ecosystems. Nature 443, 989-992.

Carey, C.C., Ibelings, B.W., Hoffmann, E.P., Hamilton, D.P., Brookes, J.D., 2012. Ecophysiological adaptations that favour freshwater cyanobacteria in a changing climate. Water Research 46, 1394-1407.

Carey, R.O., Hochmuth, G.J., Martinez, C.J., Boyer, T.H., Dukes, M.D., Toor, G.S., Cisar, J.L., 2013. Evaluating nutrient impacts in urban watersheds: Challenges and research opportunities. Environmental Pollution 173, 138-149.

Carmichael, W., 2001. Health effects of toxin-producing cyanobacteria: "The cyanoHABs." Human and Ecological Risk Assessment 7, 1393-1407.

Carpenter, S.R., Fisher, S.G., Grimm, N.B., Kitchell, J.F., 1992. Global change and freshwater ecosystems. Annual Review of Ecology and Systematics 23, 119-139.

Carpenter, S.R., Kitchell, J.F., Hodgson, J.R., 1985. Cascading Trophic Interactions and Lake Productivity. BioScience 35, 634-639.

Carpenter, S.R., Stanley, E.H., Vander Zanden, M.J., 2011. State of the world's freshwater ecosystems: Physical, chemical, and biological changes. Annual Review of Environment and Resources 36, 75-99.

Carpenter, S.R.R., Caraco, N.F., Correll, D.L., Howarth, R.W., Sharpley, A.N., Smith, V.H.H., 1998. Nonpoint pollution of surface waters with phosphorus and nitrogen. Ecological Applications 8, 559-568.

Carvalho, L., Poikane, S., Lyche Solheim, A., Phillips, G., Borics, G., Catalan, J., De Hoyos, C., Drakare, S., Dudley, B.J., Järvinen, M., Laplace-Treyture, C., Maileht, K., McDonald, C., Mischke, U., Moe, J., Morabito, G., Nõges, P., Nõges, T., Ott, I., Pasztaleniec, A., Skjelbred, B., Thackeray, S.J., 2013. Strength and uncertainty of phytoplankton metrics for assessing eutrophication impacts in lakes. Hydrobiologia 704, 127-140. 
Castillo, A.M., Sharpe, D.M.T., Ghalambor, C.K., De León, L.F., 2017. Exploring the effects of salinization on trophic diversity in freshwater ecosystems: a quantitative review. Hydrobiologia.

Cataraqui Region Conservation Authority (CRCA). 2008. Watershed Characterization Report, Chapter 1. Glenburnie, Canada.

Cataraqui Region Conservation Authority (CRCA), 2011. Cataraqui Source Protection Area Assessment Report. Glenburnie, Ontario.

Cataraqui Region Conservation Authority (CRCA). 2013. Watershed Report Card 2013. Glenburnie, Ontario.

Cataraqui Region Conservation Authority (CRCA), 2017. Cataraqui Region Lake Assessment Report 2017. Glenburnie, Ontario.

Cataraqui Region Conservation Authority (CRCA). 2018. Watershed Report Card 2018. Glenburnie, Ontario.

Catling, P.M., Mitrow, G., Haber, E., Posluszny, U., Charlton, W.A., 2003. The biology of Canadian weeds. 124. Hydrocharis morsus-ranae L. Canadian Journal of Plant Science 83, 1001-1016.

Cha, Y.K., Cho, K.H., Lee, H., Kang, T., Kim, J.H., 2017. The relative importance of water temperature and residence time in predicting cyanobacteria abundance in regulated rivers. Water Research 124, 11-19.

Chalar, G., 2009. The use of phytoplankton patterns of diversity for algal bloom management. Limnologica 39, 200-208.

Chambers, P.A., McGoldrick, D.J., Brua, R.B., Vis, C., Culp, J.M., Benoy, G.A., 2012. Development of Environmental Thresholds for Nitrogen and Phosphorus in Streams. Journal of Environmental Quality 41, 7-20.

Charlebois, P.M., Lamberti, G.A., 1996. Invading Crayfish in a Michigan Stream: Direct and Indirect Effects on Periphyton and Macroinvertebrates. Journal of the North American Benthological Society 15, 551-563.

Charron, L., Kitchen, B., O’Dell, A., Stephenson, B., 1982. Multiple use management of the Rideau and Trent-Severn waterway reservoir systems. Canadian Water Resources Journal 7, 335-349.

Chételat, J., Pick, F.R., Hamilton, P.B., 2006. Potamoplankton size structure and taxonomic composition: Influence of river size and nutrient concentrations. Limnology and Oceanography 51, 681-689.

Chételat, J., Pick, F.R., Morin, A., 2000. Patterns of periphyton biomass in three eastern Ontario rivers ranging in trophic status. Verhandlungen des Internationalen Verein Limnologie 27, 3148-3153. 
Chételat, J., Pick, F.R., Morin, A., Hamilton, P.B., 1999. Periphyton biomass and community composition in rivers of different nutrient status. Canadian Journal of Fisheries and Aquatic Sciences 56, 560-569.

Chhor, A.D., Glassman, D.M., Smol, J.P., Vermaire, J.C., Cooke, S.J., 2020. Ecological consequences of shoreline armoring on littoral fish and benthic macroinvertebrate communities in an Eastern Ontario lake. Aquatic Sciences 82, 1-13.

Christie, C.E., Smol, J.P., 1996. Limnological effects of 19th century canal construction and other disturbances on the trophic state history of upper Rideau Lake, Ontario. Lake and Reservoir Management 12, 448-454.

City of Ottawa Environmental Services Department (COESD). 2018. The Determination of Total Kjedahl Nitrogen (TKN) and Total Phosphorus (TP) in Water (LSU-OP000137). Version 2.4.

City of Ottawa, 2021. City reviewing its Winter Maintenance Quality Standards.

Collen, B., Whitton, F., Dyer, E.E., Baillie, J.E.M., Cumberlidge, N., Darwall, W.R.T., Pollock, C., Richman, N.I., Soulsby, A.M., Böhm, M., 2014. Global patterns of freshwater species diversity, threat and endemism. Global Ecology and Biogeography 23, 40-51.

Collins, G.B., Weber, C.I., 1978. Phycoperiphyton (Algae) as Indicators of Water Quality. Transactions of the American Microscopical Society 97, 36-43.

Committee on the Status of Endangered Wildlife in Canada (COSEWIC). 2011. COSEWIC Assessment and Status Report on the Silver Lamprey Ichthyomyzon unicuspis in Canada. Ottawa.

Committee on the Status of Endangered Wildlife in Canada (COSEWIC). 2016. COSEWIC Assessment and Status Report on the Blanding's Turtle Emydoidea blandingii in Canada. Ottawa.

Compton, J.A., Kerfoot, W.C., 2004. Colonizing inland lakes: Consequences of YOY fish ingesting the spiny cladoceran (Bythotrephes cederstroemi). Journal of Great Lakes Research 30, 315-326.

Corsi, S.R., De Cicco, L.A., Lutz, M.A., Hirsch, R.M., 2015. River chloride trends in snow-affected urban watersheds: Increasing concentrations outpace urban growth rate and are common among all seasons. Science of the Total Environment 508, 488-497.

Corsi, S.R., Graczyk, D.J., Geis, S.W., Booth, N.L., Richards, K.D., 2010. A fresh look at road salt: Aquatic toxicity and water-quality impacts on local, regional, and national scales. Environmental Science and Technology 44, 7376-7382.

Crocker, D.W., Barr, D.W., 1968. Handbook of the crayfishes of Ontario. University of Toronto, Toronto, Canada. 
Crowther, R.A., Hynes, H.B.N., 1977. The effect of road deicing salt on the drift of stream benthos. Environmental Pollution 14, 113-126.

Cupertino, A., Gücker, B., Von Rückert, G., Figueredo, C.C., 2019. Phytoplankton assemblage composition as an environmental indicator in routine lentic monitoring: Taxonomic versus functional groups. Ecological Indicators 101, 522-532.

Davidson, T.K., 1990. Rideau Valley Rural Beaches Program Water Quality Study 1990. Rideau Valley Conservation Authority, Ontario Ministry of the Environment.

Davis, J., Sim, L., Chambers, J., 2010. Multiple stressors and regime shifts in shallow aquatic ecosystems in antipodean landscapes. Freshwater Biology 55, 5-18.

Davis, J.A., McGuire, M., Halse, S.A., Hamilton, D., Horwitz, P., McComb, A.J., Froend, R.H., Lyons, M., Sim, L., 2003. What happens when you add salt: Predicting impacts of secondary salinisation on shallow aquatic ecosystems by using an alternative-states model. Australian Journal of Botany 51, 715-724.

DeNicola, D.M., Kelly, M., 2014. Role of periphyton in ecological assessment of lakes. Freshwater Science 33, 619-638.

Desforges, J.E., Clarke, J., Harmsen, E.J., Jardine, A.M., Robichaud, J.A., Serré, S., Chakrabarty, P., Bennett, J.R., Hanna, D.E.L., Smol, J.P., Rytwinski, J.J., Taylor, T., Martel, A.L., Winegardner, Amanda K. Marty, J., Taylor, M.K., O'Connor, Constance M. Robinson, S.A., Reid, A.J., Creed, I.F., Gregory-Eaves, I., Lapointe, N.W.R., Cooke, S.J., 2021. On the alarming state of freshwater biodiversity in Canada. Canadian Journal of Fisheries and Aquatic Sciences 55.

Detmer, T.M., Broadway, K.J., Potter, C.G., Collins, S.F., Parkos, J.J., Wahl, D.H., 2019. Comparison of microscopy to a semi-automated method ( FlowCam ${ }^{\circledR}$ ) for characterization of individual-, population-, and community-level measurements of zooplankton. Hydrobiologia 838, 99-110.

Dextrase, A.J., Mandrak, N.E., 2006. Impacts of alien invasive species on freshwater fauna at risk in Canada. Biological Invasions 8, 13-24.

Dignum, M., Matthijs, H.C.P., Pel, R., Laanbroek, H.J., Mur, L.R., 2005. Nutrient limitation of freshwater cyanobacteria. In: Huisman, J., Matthijs, H.C.P., Visser, P.M. (Eds.), Harmful Cyanobacteria. Springer, Netherlands, pp. 65-86.

Dodds, W.K., Bouska, W.W., Eitzmann, J.L., Pilger, T.J., Pitts, K.L., Riley, A.J., Schloesser, J.T., Thornbrugh, D.J., 2009. Eutrophication of U. S. freshwaters: Analysis of potential economic damages. Environmental Science and Technology $43,12-19$.

Dokulil, M.T., Teubner, K., 2000. Cyanobacterial dominance in lakes. Hydrobiologia $438,1-12$. 
Dottne-Lindgren, A., Ekbohm, G., 1975. Ceratium hirundinella in Lake Erken: Horizontal distribution and form variation. Internationale Revue der gesamten Hydrobiologie und Hydrographie 60, 115-144.

Dudgeon, D., Arthington, A.H., Gessner, M.O., Kawabata, Z.I., Knowler, D.J., Lévêque, C., Naiman, R.J., Prieur-Richard, A.H., Soto, D., Stiassny, M.L.J., Sullivan, C.A., 2006. Freshwater biodiversity: Importance, threats, status and conservation challenges. Biological Reviews of the Cambridge Philosophical Society 81, $163-$ 182.

Dudley, J.L., Arthurs, W., Hall, T.J., 2001. A Comparison of Methods Used to Estimate River Rock Surface Areas. Journal of Freshwater Ecology 16, 257-261.

Dynesius, M., Nilsson, C., 1994. Fragmentation and flow regulation of river systems in the northern third of the world. Science 266, 753-762.

Ecoplans, Hodgins, B., 2013. Synthesis of Best Practises - Road Salt Management.

EDDMapS. 2021. Early Detection \& Distribution Mapping System. The University of Georgia - Center for Invasive Species and Ecosystem Health. http://www.eddmaps.org/.

Environment Canada, 2012. Five-year Review of Progress: Code of Practice for the Environmental Management of Road Salts.

Evans, M., Frick, C., 2001. The effects of road salts on aquatic ecosystems. WSTD Contribution No. 02-308. Environment Canada, Water Science and Technology Directorate, Saskatoon, Saskatchewan.

Feipeng, L., Haiping, Z., Yiping, Z., Yihua, X., Ling, C., 2013. Effect of flow velocity on phytoplankton biomass and composition in a freshwater lake. Science of the Total Environment 447, 64-71.

Fenchel, T., Finlay, B.J., 2004. The ubiquity of small species: Patterns of local and global diversity. BioScience 54, 777-784.

Flecker, A.S., Townsend, C.R., 1994. Community-Wide Consequences of Trout Introduction in New Zealand Streams. Ecological Applications 4, 789-807.

Fleming, J.P., Dibble, E.D., 2015. Ecological mechanisms of invasion success in aquatic macrophytes. Hydrobiologia 746, 23-37.

Foley, B., Jones, I.D., Maberly, S.C., Rippey, B., 2012. Long-term changes in oxygen depletion in a small temperate lake: Effects of climate change and eutrophication. Freshwater Biology 57, 278-289. 
Foley, J.A., DeFries, R., Asner, G.P., Barford, C., Bonan, G., Carpenter, S.R., Chapin, F.S., Coe, M.T., Daily, G.C., Gibbs, H.K., Helkowski, J.H., Holloway, T., Howard, E.A., Kucharik, C.J., Monfreda, C., Patz, J.A., Prentice, I.C., Ramankutty, N., Snyder, P.K., 2005. Global consequences of land use. Science 309, 570-574.

Fontaneto, D., 2011. Biogeography of Microscopic Organisms: Is Everything Small Everywhere? Cambridge University Press, Cambridge, UK.

Forrest, F., Reavie, E.D., Smol, J.P., 2003. Comparing limnological changes associated with 19th century canal construction and other catchment disturbances in four lakes within the Rideau Canal system, Ontario, Canada. Journal of Limnology 61, 183197.

Friberg, N., Bonada, N., Bradley, D.C., Dunbar, M.J., Edwards, F.K., Grey, J., Hayes, R.B., Hildrew, A.G., Lamouroux, N., Trimmer, M., Woodward, G., 2011. Biomonitoring of Human Impacts in Freshwater Ecosystems. Advances in Ecological Research 44, 1-68.

Fuller, M.R., Doyle, M.W., Strayer, D.L., 2015. Causes and consequences of habitat fragmentation in river networks. Annals of the New York Academy of Sciences $1355,31-51$.

Gallardo, B., Clavero, M., Sánchez, M.I., Vilà, M., 2016. Global ecological impacts of invasive species in aquatic ecosystems. Global Change Biology 22, 151-163.

Garvey, J.E., Stein, R.A., Thomas, H.M., 1994. Assessing how fish predation and interspecific prey competition influence a crayfish assemblage. Ecology 75, 532547.

Gaston, K.J., 2000. Global Patterns in Biodiversity. Nature 405, 220-227.

Giblin, S.M., Gerrish, G.A., 2020. Environmental factors controlling phytoplankton dynamics in a large floodplain river with emphasis on cyanobacteria. River Research and Applications 36, 1137-1150.

Gilbert, J.J., 1996. Effect of Temperature on the Response of Planktonic Rotifers to a Toxic Cyanobacterium. Ecology 77, 1174-1180.

Godwin, K.S., Hafner, S.D., Buff, M.F., 2003. Long-term trends in sodium and chloride in the Mohawk River, New York: The effect of fifty years of road-salt application. Environmental Pollution 124, 273-281.

Graham, M.D., Cook, J., Graydon, J., Kinniburgh, D., Nelson, H., Pilieci, S., Vinebrooke, R.D., 2018. High-resolution imaging particle analysis of freshwater cyanobacterial blooms. Limnology and Oceanography: Methods 16, 669-679.

Gross, E.M., Meyer, H., Schilling, G., 1995. Release and ecological impact of algicidal hydrolysable polyphenols in Myriophyllum spicatum. Phytochemistry 41, 133-138. 
Guillet, G.R., 1977. Clay and shale deposits of Ontario: Mineral Deposits Circular MDC15.

Haag, W.R., Berg, D.J., Garton, D.W., Farris, J.L., 1993. Reduced survival and fitness in native bivalves in response to fouling by the introduced zebra mussel (Dreissena polymorpha) in western Lake Erie. Canadian Journal of Fisheries and Aquatic Sciences 50, 13-19.

Hallegraeff, G.M., 1993. A Review of Harmful Algal Blooms and Their Apparent Global Increase. Phycologia 32, 79-99.

Hambrook Berkman, J.A., Canova, M.G., 2007. Chapter A7. Section 7.4. Algal biomass indicators, Techniques of Water-Resources Investigations, Book 9. Reston, VA.

Hamilton, P.B., Lavoie, I., Ley, L.M., Poulin, M., 2011. Factors contributing to the spatial and temporal variability of phytoplankton communities in the Rideau River (Ontario, Canada). River Systems 19, 189-205.

Hamilton, P.B., Lavoie, I., Poulin, M., 2012. Spatial, seasonal and inter-annual variability in environmental characteristics and phytoplankton standing stock of the temperate, lowland Rideau River, Ontario, Canada. River Research and Applications 28, $1551-1566$.

Hansson, L. -A, 1988. Effects of competitive interactions on the biomass development of planktonic and periphytic algae in lakes. Limnology and Oceanography 33, 121128.

Harrell Jr., F.E., 2020. R Package "hmisc". Version 4.4-0.

Harris, G.P., 1980. Temporal and Spatial Scales in Phytoplankton Ecology. Mechanisms, Methods, Models, and Management. Canadian Journal of Fisheries and Aquatic Sciences 37, 877-900.

Harris, G.P., Heaney, S.I., Talling, J.F., 1979. Physiological and environmental constraints in the ecology of the planktonic dinoflagellate Ceratium hirundinella. Freshwater Biology 9, 413-428.

Heaney, S.I., 1976. Temporal and spatial distribution of the dinoflagellate Ceratium hirundinella O.F. Müller within a small productive lake. Freshwater Biology 6, 531-542.

Hecky, R.E., Kilham, P., 1988. Nutrient limitation of phytoplankton in freshwater and marine environments: A review of recent evidence on the effects of enrichment, Limnology and Oceanography.

Hill, B.H., Herlihy, A.T., Kaufmann, P.R., Stevenson, R.J., McCormick, F.H., Burch Johnson, C., 2000. Use of periphyton assemblage data as an index of biotic integrity. Journal of the North American Benthological Society 19, 50-67. 
Hillebrand, H., Dürselen, C.D., Kirschtel, D., Pollingher, U., Zohary, T., 1999. Biovolume calculation for pelagic and benthic microalgae. Journal of Phycology $35,403-424$.

Hintz, W.D., Mattes, B.M., Schuler, M.S., Jones, D.K., Stoler, B., Lind, L., Relyea, R.A., 2017. Salinization triggers a trophic cascade in experimental freshwater communities with varying food-chain length. Ecological Applications 27, 833-844.

Hintz, W.D., Relyea, R.A., 2019. A review of the species, community, and ecosystem impacts of road salt salinisation in fresh waters. Freshwater Biology 64, 10811097.

Hofmann, N., Filoso, G., Schofield, M., 2005. The loss of dependable agricultural land in Canada. Rural and Small Town Canada Analysis Bulletin 6, Ottawa: Statistics Canada, Catalogue no. 21-006-X.

Holland, A.J., Gordon, A.K., Muller, W.J., 2011. Osmoregulation in freshwater invertebrates in response to exposure to salt pollution. Grahamstown, South Africa.

Hötzel, G., Croome, R., 1996. Population dynamics of Aulacoseira granulata (EHR.) SIMONSON (Bacillariophyceae, Centrales), the dominant alga in the Murray River, Australia. Archiv fur Hydrobiologie 136, 191-215.

Houser, J.N., Richardson, W.B., 2010. Nitrogen and phosphorus in the Upper Mississippi River: Transport, processing, and effects on the river ecosystem. Hydrobiologia $640,71-88$.

Hrycik, A.R., Shambaugh, A., Stockwell, J.D., 2019. Comparison of FlowCam and microscope biovolume measurements for a diverse freshwater phytoplankton community. Journal of Plankton Research 41, 849-864.

Huber, V., Adrian, R., Gerten, D., 2008. Phytoplankton response to climate warming modified by trophic state. Limnology and Oceanography 53, 1-13.

Huisman, J., Codd, G.A., Paerl, H.W., Ibelings, B.W., Verspagen, J.M.H., Visser, P.M., 2018. Cyanobacterial blooms. Nature Reviews Microbiology 16, 471-483.

Huser, B.J., Futter, M.N., Wang, R., Fölster, J., 2018. Persistent and widespread longterm phosphorus declines in Boreal lakes in Sweden. Science of the Total Environment 613-614, 240-249.

Hutchinson, G.E., 1961. The Paradox of the Plankton. The American Naturalist 95, 137145.

Ibáñez, C., Peñuelas, J., 2019. Changing nutrients, changing rivers. Science 365, 637638. 
Ibelings, B., Admiraal, W., Bijkerk, R., Ietswaart, T., Prins, H., 1998. Monitoring of algae in Dutch rivers: Does it meet its goals? Journal of Applied Phycology 10, $171-181$.

International Organization for Standardization (ISO), 1992. Water quality measurement of biochemical parameters spectrophotometric determination of chlorophyll-a concentration, International Organization for Standardization.

Jackson, D.A., 1993. Stopping Rules in Principal Components Analysis: A Comparison of Heuristical and Statistical Approaches. Ecology 74, 2204-2214.

Jackson, M.C., Loewen, C.J.G., Vinebrooke, R.D., Chimimba, C.T., 2016. Net effects of multiple stressors in freshwater ecosystems: a meta-analysis. Global Change Biology 22, 180-189.

Jane, S.F., Hansen, G.J.A., Kraemer, B.M., Leavitt, P.R., Mincer, J.L., North, R.L., Pilla, R.M., Stetler, J.T., Williamson, C.E., Woolway, R.I., Arvola, L., Chandra, S., DeGasperi, C.L., Diemer, L., Dunalska, J., Erina, O., Flaim, G., Grossart, H.-P., Hambright, K.D., Hein, C., Hejzlar, J., Janus, L.L., Jenny, J.-P., Jones, J.R., Knoll, L.B., Leoni, B., Mackay, E., Matsuzaki, S.-I.S., McBride, C., Müller-Navarra, D.C., Paterson, A.M., Pierson, D., Rogora, M., Rusak, J.A., Sadro, S., SaulnierTalbot, E., Schmid, M., Sommaruga, R., Thiery, W., Verburg, P., Weathers, K.C., Weyhenmeyer, G.A., Yokota, K., Rose, K.C., 2021. Widespread deoxygenation of temperate lakes. Nature 594, 66-70.

Janus, L.L., Vollenweider, R.A., 1981. OECD Cooperative Programme On Eutrophication: Canadian Contribution. Burlington, Canada.

Jeffrey, S.W., Humphrey, G.F., 1975. New spectrophotometric equations for determining chlorophylls a, b, $\mathrm{c}_{1}$ and $\mathrm{c}_{2}$ in higher plants, algae and natural phytoplankton. Biochemie und Physiologie der Pflanzen 167, 191-194.

Jöhnk, K.D., Huisman, J., Sharples, J., Sommeijer, B., Visser, P.M., Stroom, J.M., 2008. Summer heatwaves promote blooms of harmful cyanobacteria. Global Change Biology 14, 495-512.

Kahlert, M., Gottschalk, S., 2014. Differences in benthic diatom assemblages between streams and lakes in Sweden and implications for ecological assessment. Freshwater Science 33, 655-669.

Karst, T.L., Smol, J.P., 2000. Paleolimnological evidence of limnetic nutrient concentration equilibrium in a shallow, macrophyte-dominated lake. Aquatic Sciences 62, 20-38.

Kasprzak, P., Padisák, J., Koschel, R., Krienitz, L., Gervais, F., 2008. Chlorophyll a concentration across a trophic gradient of lakes: An estimator of phytoplankton biomass? Limnologica 38, 327-338. 
Kaushal, S.S., Groffman, P.M., Likens, G.E., Belt, K.T., Stack, W.P., Kelly, V.R., Band, L.E., Fisher, G.T., 2005. Increased salinization of fresh water in the Northeastern United States. Proceedings of the National Academy of Sciences of the United States of America 102, 13517-13520.

Kelly, L.A., Hassall, C., 2018. The spatial ecology of phytoplankton blooms in UK canals. Inland Waters 8, 422-433.

Kernan, M., Battarbee, R.W., Moss, B., 2010. Climate Change Impacts on Freshwater Ecosystems. Climate Change Impacts on Freshwater Ecosystems 1-314.

Kerr, J.G., 2017. Multiple land use activities drive riverine salinization in a large, semiarid river basin in western Canada. Limnology and Oceanography 62, 1331-1345.

Knoll, L.B., Sarnelle, O., Hamilton, S.K., Kissman, C.E.H., Wilson, A.E., Rose, J.B., Morgan, M.R., 2008. Invasive zebra mussels (Dreissena polymorpha) increase cyanobacterial toxin concentrations in low-nutrient lakes. Canadian Journal of Fisheries and Aquatic Sciences 65, 448-455.

Köhler, J., 1993. Growth, production and losses of phytoplankton in the lowland River Spree. I. Population dynamics. Journal of Plankton Research 15, 335-349.

Köhler, J., 1994. Origin and succession of phytoplankton in a river-lake system (Spree, Germany). In: Descy, J.-P., Reynolds, C.S., Padisák, J. (Eds.), Phytoplankton in Turbid Environments: Rivers and Shallow Lakes: Proceedings of the 9th Workshop of the International Association of Phytoplankton Taxonomy and Ecology (IAP) Held in Mont Rigi (Belgium), 10-18 July 1993. Springer Netherlands, Dordrecht, pp. 73-83.

Kristiansen, J., 1996. Dispersal of freshwater algae - a review. Hydrobiologia 336, 151157.

Lampert, W., Fleckner, W., Rai, H., Taylor, B.E., 1986. Phytoplankton control by grazing zooplankton: A study on the spring clear-water phase. Limnology and Oceanography 31, 478-490.

Larned, S.T., 2010. A prospectus for periphyton: Recent and future ecological research. Journal of the North American Benthological Society 29, 182-206.

Lathrop, R.C., Carpenter, S.R., Rudstam, L.G., 1996. Water clarity in Lake Mendota since 1900: Responses to differing levels of nutrients and herbivory. Canadian Journal of Fisheries and Aquatic Sciences 53, 2250-2261.

Latifovic, R., Pouliot, D., 2007. Analysis of climate change impacts on lake ice phenology in Canada using the historical satellite data record. Remote Sensing of Environment 106, 492-507. 
Lederer, A., Massart, J., Janssen, J., 2006. Impact of round gobies (Neogobius melanostomus) on dreissenids (Dreissena polymorpha and Dreissena bugensis) and the associated macroinvertebrate community across an invasion front. Journal of Great Lakes Research 32, 1-10.

Leibold, M.A., Holyoak, M., Mouquet, N., Amarasekare, P., Chase, J.M., Hoopes, M.F., Holt, R.D., Shurin, J.B., Law, R., Tilman, D., Loreau, M., Gonzalez, A., 2004. The metacommunity concept: A framework for multi-scale community ecology. Ecology Letters 7, 601-613.

Lodge, D.M., Lorman, J.G., 1987. Reductions in submersed macrophyte biomass and species richness by the crayfish Orconectes rusticus. Canadian Journal of Fisheries and Aquatic Sciences 44, 591-597.

Lohman, K., Jones, J.R., Perkins, B.D., 1992. Effects of nutrient enrichment and flood frequency on periphyton biomass in northern Ozark streams. Canadian Journal of Fisheries and Aquatic Sciences 49, 1198-1205.

Lorenz, C.M., Van Dijk, G.M., Van Hattum, A.G.M., Cofino, W.P., 1997. Concepts in river ecology: Implications for indicator development. Regulated Rivers: Research and Management 13, 501-516.

Lorenzen, C.J., 1967. Determination of Chlorophyll and Pheo-Pigments: Spectrophotometric Equations. Limnology and Oceanography 12, 343-346.

Lowe, R.L., Pillsbury, R.W., 1995. Shifts in Benthic Algal Community Structure and Function Following the Appearance of Zebra Mussels (Dreissena polymorpha) in Saginaw Bay, Lake Huron. Journal of Great Lakes Research.

MacIsaac, H.J., 1996. Potential Abiotic and Biotic Impacts of Zebra Mussels on the Inland Waters of North America. American Zoology 36, 287-299.

Madsen, J.D., Sutherland, J.W., Bloomfield, J.A., Eichler, L.W., Boylen, C.W., 1991. The decline of native vegetation under dense Eurasian watermilfoil canopies. Journal of Aquatic Plant Management 29, 94-99.

Maier, H.R., Kingston, G.B., Clark, T., Frazer, A., Sanderson, A., 2004. Risk-based approach for assessing the effectiveness of flow management in controlling cyanobacterial blooms in rivers. River Research and Applications 20, 459-471.

Mantyka-Pringle, C.S., Martin, T.G., Moffatt, D.B., Linke, S., Rhodes, J.R., 2014. Understanding and predicting the combined effects of climate change and land-use change on freshwater macroinvertebrates and fish. Journal of Applied Ecology 51, $572-581$.

Martel, A., 1995. Demography and growth of the exotic zebra mussel (Dreissena polymorpha) in the Rideau River (Ontario). Canadian Journal of Zoology 73, 2244-2250. 
Martel, A.L., Madill, J.B., 2018. Twenty-six years (1990-2015) of monitoring annual recruitment of the invasive zebra mussel (Dreissena polymorpha) in the Rideau River, a small river system in Eastern Ontario, Canada. Canadian Journal of Zoology 96, 1071-1079.

McCormick, P. V, Cairns, J., 1994. Algae as indicators of environmental change. Journal of Applied Phycology 6, 509-526.

McKinney, M.L., 2006. Urbanization as a major cause of biotic homogenization. Biological Conservation 127, 247-260.

McQueen, D.J., Post, J.R., Mills, E.L., 1986. Trophic Relationships in Freshwater Pelagic Ecosystems. Canadian Journal of Fisheries and Aquatic Sciences 43, 1571-1581.

Meador, M.R., Goldstein, R.M., 2003. Assessing Water Quality at Large Geographic Scales: Relations Among Land Use, Water Physicochemistry, Riparian Condition, and Fish Community Structure. Environmental Management 31, 0504-0517.

Meybeck, M., 2003. Global analysis of river systems: From Earth system controls to Anthropocene syndromes. Philosophical Transactions of the Royal Society B: Biological Sciences 358, 1935-1955.

Meyer, W.B., Turner, B.L., 1996. Land-use/land-cover change: Challenges for geographers. GeoJournal 39, 237-240.

Miller, R.R., Williams, J.D., Williams, J.E., 1989. Extinctions of North American Fishes During the past Century. Fisheries 14, 22-38.

Ministry of the Environment, 1979. Rationale for the establishment of Ontario's provincial water quality objectives. Toronto, Ontario.

Mistry, I., Beaudoin, C., Kotecha, J., Evans, H., Stevens, M., Vermaire, J.C., Cooke, S., Young, N., 2021. Action research to improve water quality in Canada's Rideau Canal: How do local groups reshape environmental governance? Local Environment 26, 575-594.

Moffett, E.R., Baker, H.K., Bonadonna, C.C., Shurin, J.B., Symons, C.C., 2020. Cascading effects of freshwater salinization on plankton communities in the Sierra Nevada. Limnology and Oceanography Letters.

Mohammed, A.A., Shafea, A.A., 1992. Growth and some metabolic activities of Scenedesmus obliquus cultivated under different $\mathrm{NaCl}$ concentrations. Biologia Plantarum 34, 423-430.

Mooney, H.A., Cleland, E.E., 2001. The evolutionary impact of invasive species. Proceedings of the National Academy of Sciences of the United States of America 98, 5446-5451. 
Morgan II, R.P., Kline, K.M., Cushman, S.F., 2007. Relationships among nutrients, chloride and biological indices in urban Maryland streams. Urban Ecosystems 10, $153-166$.

Mosley, L.M., 2015. Drought impacts on the water quality of freshwater systems: review and integration. Earth-Science Reviews 140, 203-214.

Moss, B., 1972. Studies on Gull Lake, Michigan I. Seasonal and depth distribution of phytoplankton. Freshwater Biology 2, 289-307.

Moss, B., Balls, H., 1989. Phytoplankton distribution in a floodplain lake and river system. II Seasonal changes in the phytoplankton communities and their control by hydrology and nutrient availability. Journal of Plankton Research 11, 839-867.

Moss, B., Kosten, S., Meerhoff, M., Battarbee, R.W., Jeppesen, E., Mazzeo, N., Havens, K., Lacerot, G., Liu, Z., Meester, L. De, Paerl, H., Scheffer, M., 2011. Allied attack: climate change and eutrophication. Inland Waters 1, 101-105.

Moyle, P.B., Light, T., 1996. Biological invasions of fresh water: Empirical rules and assembly theory. Biological Conservation 78, 149-161.

Nagy, C.R., Lockaby, G.B., Kalin, L., Anderson, C., 2012. Effects of urbanization on stream hydrology and water quality: The Florida Gulf Coast. Hydrological Processes 26, 2019-2030.

Naiman, R.J., Turner, M.G., 2000. A future perspective on north America's freshwater ecosystems. Ecological Applications 10, 958-970.

Nakai, S., Inoue, Y., Hosomi, M., Murakami, A., 2000. Myriophyllum spicatum-released allelopathic polyphenols inhibiting growth of blue-green algae Microcystis aeruginosa. Water Research 34, 3026-3032.

Natural Earth. 2018. 1:10m Physical Vectors. https://www.naturalearthdata.com/downloads/10m-physical-vectors/.

Natural Resources Canada. 2017. Lakes, Rivers and Glaciers in Canada - CanVec Series Hydrographic Features. https:/open.canada.ca/data/en/dataset/9d96e8c9-22fe4ad2-b5e8-94a6991b744b.

Nicholls, K.H., Dillon, P.J., 1978. An Evaluation of Phosphorus-ChlorophyllPhytoplankton Relationships for Lakes. Internationale Revue der gesamten Hydrobiologie und Hydrographie 63, 141-154.

Nicholls, K.H., Kennedy, W., Hammett, C., 1980. A fish-kill in Heart Lake, Ontario, associated with the collapse of a massive population of Ceratium hirundinella (Dinophyceae). Freshwater Biology 10, 553-561.

Nijssen, B., O’Donnell, G.M., Hamlet, A.F., Lettenmaier, D.P., 2001. Hydrologic sensitivity of global rivers to climate change. Climatic Change 50, 143-175. 
Nilsson, C., Berggren, K., 2000. Alterations of riparian ecosystems caused by river regulation. BioScience 50, 783-792.

Novotny, V., Olem, H., 1994. Water quality: prevention, identification and management of diffuse pollution. Van Nostrand Reinhold, New York, NY.

O'Brien, P.J., Wehr, J.D., 2010. Periphyton biomass and ecological stoichiometry in streams within an urban to rural land-use gradient. Hydrobiologia 657, 89-105.

Oksanen, J., Blanchet, F.G., Friendly, M., Kindt, R., Legendre, P., Mcglinn, D., Minchin, P.R., O’Hara, R.B., Simpson, G.L., Solymos, P., Henry, M., Stevens, H., Szoecs, E., Maintainer, H.W., 2019. R Package "vegan". Version 2.5-6.

Oliver, B.G., Milne, J.B., LaBarre, N., 1974. Chloride and lead in urban snow. Journal of the Water Pollution Control Federation 46, 766-771.

Ontario Ministry of Environment and Climate Change (OMECC). 2018. Provincial (Stream) Water Quality Monitoring Network. https://data.ontario.ca/dataset/provincial-stream-water-quality-monitoring-network.

Ontario Ministry of Environment and Energy (OMEE). 1994. Water management: Policies, guidelines, Provincial Water Quality Objectives. https://www.ontario.ca/page/water-management-policies-guidelines-provincialwater-quality-objectives.

Ontario Ministry of Natural Resources and Forestry (OMNRF). 2019. Southern Ontario Land Resource Information System (SOLRIS) Land Use Data (version 3.0). Peterborough, Ontario. https://geohub.lio.gov.on.ca/datasets/0279f65b82314121b5b5ec93d76bc6ba.

Ontario Ministry of Natural Resources and Forestry (OMNRF). 2020. Ontario Watershed Boundaries (version 1.2). Peterborough, Ontario. https://geohub.lio.gov.on.ca/maps/mnrf::ontario-watershed-boundaries-owb/about/.

Ormerod, S.J., Dobson, M., Hildrew, A.G., Townsend, C.R., 2010. Multiple stressors in freshwater ecosystems. Freshwater Biology 55, 1-4.

Osborne, L.L., Kovacic, D.A., 1993. Riparian vegetated buffer strips in water-quality restoration and stream management. Freshwater Biology 29, 243-258.

Ottawa Riverkeeper. 2020. Road Salt Monitoring. https://www.ottawariverkeeper.ca/what-we-do-2/initiatives/watershed-healthassessment-and-monitoring/road-salt-monitoring/.

Padisák, J., Hajnal, É., Naselli-Flores, L., Dokulil, M.T., Nõges, P., Zohary, T., 2010. Convergence and divergence in organization of phytoplankton communities under various regimes of physical and biological control. Hydrobiologia 639, 205-220. 
Paerl, H.W., Fulton, R.S., Moisander, P.H., Dyble, J., 2001. Harmful freshwater algal blooms, with an emphasis on cyanobacteria. TheScientificWorldJournal 1, 76-113.

Paerl, H.W., Gardner, W.S., Havens, K.E., Joyner, A.R., McCarthy, M.J., Newell, S.E., Qin, B., Scott, J.T., 2016. Mitigating cyanobacterial harmful algal blooms in aquatic ecosystems impacted by climate change and anthropogenic nutrients. Harmful Algae 54, 213-222.

Paerl, H.W., Hall, N.S., Calandrino, E.S., 2011. Controlling harmful cyanobacterial blooms in a world experiencing anthropogenic and climatic-induced change. Science of the Total Environment 409, 1739-1745.

Paerl, H.W., Shimp, S.L., 1973. Preparation of filtered plankton and detritus for study with scanning electron microscopy. Limnology and Oceanography 18, 802-805.

Paine, R.T., 1966. Food web complexity and species diversity. The American Naturalist $100,65-75$.

Palmer, M.A., Covich, A.P., Finlay, B.J., Gibert, J., Hyde, K.D., Johnson, R.K., Kairesalo, T., Lake, S., Lovell, C.R., Naiman, R.J., Ricci, C., Sabater, F., Strayer, D., 1997. Biodiversity and ecosystem processes in freshwater sediments. Ambio 26, 571-577.

Palmer, M.A., Lettenmaier, D.P., Poff, N.L., Postel, S.L., Richter, B., Warner, R., 2009. Climate change and river ecosystems: Protection and adaptation options. Environmental Management 44, 1053-1068.

Parks Canada, 2005. Rideau Canal - National Historic Site of Canada - Management Plan. Ottawa, Ontario.

Parks Canada, 2006. Nomination of the Rideau Canal by the Government of Canada, 2006 for Inscription on the World Heritage List.

Parks Canada. 2021. Rideau Canal: History and culture. https://www.pc.gc.ca/en/lhnnhs/on/rideau/histoire-history.

Patrick, R., Cairns Jr., J., Scheier, A., 1968. The relative sensitivity of diatoms, snails, and fish to twenty common constituents of industrial wastes. Progressive FishCulturist 30, 137-140.

Paul, M.J., Meyer, J.L., 2001. Streams in the Urban Landscape. Annual Review of Ecology and Systematics 32, 333-365.

Perrings, C., Dehnen-Schmutz, K., Touza, J., Williamson, M., 2005. How to manage biological invasions under globalization. Trends in Ecology and Evolution 20, 212 215 . 
Pick, F.R., 2016. Blooming algae: A Canadian perspective on the rise of toxic cyanobacteria. Canadian Journal of Fisheries and Aquatic Sciences 73, 11491158 .

Piggott, J.J., Salis, R.K., Lear, G., Townsend, C.R., Matthaei, C.D., 2015. Climate warming and agricultural stressors interact to determine stream periphyton community composition. Global Change Biology 21, 206-222.

Pillsbury, R.W., Lowe, R.L., Yang, D.P., Greenwood, J.L., 2002. Changes in the benthic algal community and nutrient limitation in Saginaw Bay, Lake Huron, during the invasion of the zebra mussel (Dreissena polymorpha). Journal of the North American Benthological Society 21, 238-252.

Poff, N., Allan, J., Bain, M., Karr, J., Prestegaard, K., Richter, B., Sparks, R., Stromberg, J., 1997. The Natural Flow Regime. Bioscience 47, 769-784.

Poulin, M., 2001. A multidisciplinary, community-based study of the environmental health of the Rideau River: Final report. Ottawa.

Puckett, L.J., 1995. Identifying the Major Sources of Nutrient Water Pollution. Environmental Science \& Technology 29, 408A-414A.

Quinn, J.M., Cooper, A.B., Stroud, M.J., Burrell, G.P., 1997. Shade effects on stream periphyton and invertebrates: An experiment in streamside channels. New Zealand Journal of Marine and Freshwater Research 31, 665-683.

R Core Team, 2019. R: A language and environment for statistical computing. $R$ Foundation for Statistical Computing.

Rahel, F.J., 2002. Homogenization of freshwater faunas. Annual Review of Ecology and Systematics 33, 291-315.

Rahel, F.J., 2007. Biogeographic barriers, connectivity and homogenization of freshwater faunas: It's a small world after all. Freshwater Biology 52, 696-710.

Rahel, F.J., Olden, J.D., 2008. Assessing the effects of climate change on aquatic invasive species. Conservation Biology.

Raney, S.M., Eimers, M.C., 2014. Unexpected declines in stream phosphorus concentrations across southern Ontario. Canadian Journal of Fisheries and Aquatic Sciences 71, 337-342.

Rao, C., 1995. A review of canonical coordinates and an alternative to correspondence analysis using Hellinger distance. Questiió. 
Reid, A.J., Carlson, A.K., Creed, I.F., Eliason, E.J., Gell, P.A., Johnson, P.T.J., Kidd, K.A., MacCormack, T.J., Olden, J.D., Ormerod, S.J., Smol, J.P., Taylor, W.W., Tockner, K., Vermaire, J.C., Dudgeon, D., Cooke, S.J., 2019. Emerging threats and persistent conservation challenges for freshwater biodiversity. Biological Reviews 94, 849-873.

Reid, S.M., Nocera, J.J., 2015. Composition of native crayfish assemblages in southern Ontario rivers affected by rusty crayfish (Orconectes rusticus Girard, 1852) invasions - implications for endangered queensnake recovery. Aquatic Invasions 10, 189-198.

Revenga, C., Campbell, I., Abell, R., De Villiers, P., Bryer, M., 2005. Prospects for monitoring freshwater ecosystems towards the 2010 targets. Philosophical Transactions of the Royal Society B: Biological Sciences 360, 397-413.

Reynolds, C.S., 1989. Physical Determinants of Phytoplankton Succession. In: Plankton Ecology. pp. 9-56.

Reynolds, C.S., 2000. Hydroecology of river plankton: the role of variability in channel flow. Hydrological Processes 14, 3119-3132.

Reynolds, C.S., Descy, J.-P., 1996. The production, biomass and structure of phytoplankton in large rivers. Archiv für Hydrobiologie.

Reynolds, C.S., Descy, J.P., Padisák, J., 1994. Are phytoplankton dynamics in rivers so different from those in shallow lakes? Hydrobiologia 289, 1-7.

Reynolds, C.S., Glaister, M.S., 1993. Spatial and temporal changes in phytoplankton abundance in the upper and middle reaches of the River Severn. River Systems 9 , $1-22$.

Reynolds, C.S., Walsby, A.E., 1975. Water blooms. Biological Reviews of the Cambridge Philosophical Society 50, 437-481.

Ricciardi, A., MacIsaac, H.J., 2010. Impacts of Biological Invasions on Freshwater Ecosystems. In: Richardson, D.M. (Ed.), Fifty Years of Invasion Ecology: The Legacy of Charles Elton. Blackwell Publishing Ltd, Oxford, United Kingdom, pp. 211-224.

Ricciardi, A., Neves, R.J., Rasmussen, J.B., 1998. Impending extinctions of North American freshwater mussels (Unionoida) following the zebra mussel (Dreissena polymorpha) invasion. Journal of Animal Ecology 67, 613-619.

Ricciardi, A., Whoriskey, F.G., Rasmussen, J.B., 1996. Impact of the Dreissena invasion on native unionid bivalves in the upper St. Lawrence River. Canadian Journal of Fisheries and Aquatic Sciences 53, 1434-1444.

Rideau Valley Conservation Authority (RVCA) Landcover Data. 2019. Rideau Valley Conservation Authority. https://rvcagis.github.io/jkan/datasets/rvca-landcover/. 
Rideau Valley Conservation Authority (RVCA), 2012. Lower Rideau Subwatershed Report. Manotick, Ontario.

Rideau Valley Conservation Authority (RVCA), 2014. Rideau Lakes Subwatershed Report. Manotick, Ontario.

Rigosi, A., Carey, C.C., Ibelings, B.W., Brookes, J.D., 2014. The interaction between climate warming and eutrophication to promote cyanobacteria is dependent on trophic state and varies among taxa. Limnology and Oceanography 59, 99-114.

Roberts, A.D., Prince, S.D., Jantz, C.A., Goetz, S.J., 2009. Effects of projected future urban land cover on nitrogen and phosphorus runoff to Chesapeake Bay. Ecological Engineering 35, 1758-1772.

Rolls, R.J., Heino, J., Ryder, D.S., Chessman, B.C., Growns, I.O., Thompson, R.M., Gido, K.B., 2018. Scaling biodiversity responses to hydrological regimes. Biological Reviews 93, 971-995.

Rosegrant, M.W., Cai, X., Cline, S.A., 2003. Will the world run dry? Global water and food security. Environment 45, 24-36.

Sala, O.E., Chapin, F.S., Armesto, J.J., Berlow, E., Bloomfield, J., Dirzo, R., HuberSanwal, d E., Huenneke, L.F., Jackson, R.B., Kinzig, A., Leemans, R., Lodge, D.M., Mooney, H.A., Oesterheld, M., Poff, N.L., Sykes, M.T., Walke, r B.H., Walker, M., Wall, D.H., 2000. Global biodiversity scenarios for the year 2100 . Science 287, 1770-1774.

Salmaso, N., Braioni, M.G., 2008. Factors controlling the seasonal development and distribution of the phytoplankton community in the lowland course of a large river in Northern Italy (River Adige). Aquatic Ecology 42, 533-545.

Salmaso, N., Zignin, A., 2010. At the extreme of physical gradients: Phytoplankton in highly flushed, large rivers. Hydrobiologia 639, 21-36.

Sand-Jensen, K., Borum, J., 1991. Interactions among phytoplankton, periphyton, and macrophytes in temperate freshwaters and estuaries. Aquatic Botany 41, 137-175.

Sartory, D.P., Grobbelaar, J.U., 1984. Extraction of chlorophyll a from freshwater phytoplankton for spectrophotometric analysis. Hydrobiologia 114, 177-187.

Scheffer, M., 1990. Multiplicity of stable states in freshwater systems. Hydrobiologia 200, 475-486.

Scheffer, M., Carpenter, S.R., Lenton, T.M., Bascompte, J., Brock, W., Dakos, V., Van De Koppel, J., Van De Leemput, I.A., Levin, S.A., Van Nes, E.H., Pascual, M., Vandermeer, J., 2012. Anticipating critical transitions. Science 338, 344-348.

Scheffer, M., Hosper, S.H., Meijer, M.-L., Moss, B., Jeppesen, E., 1993. Alternative Equilibria in Shallow Lakes. Trends in Ecology and Evolution 8, 275-279. 
Scheffer, M., Szabó, S., Gragnani, A., Van Nes, E.H., Rinaldi, S., Kautsky, N., Norberg, J., Roijackers, R.M.M., Franken, R.J.M., 2003. Floating plant dominance as a stable state. Proceedings of the National Academy of Sciences of the United States of America 100, 4040-4045.

Schindler, D.E., Knapp, R.A., Leavitt, P.R., 2001. Alteration of nutrient cycles and algal production resulting from fish introductions into Mountain Lakes. Ecosystems 4, 308-321.

Schindler, D.W., 1971. Carbon, nitrogen, and phosphorus and the eutrophication of freshwater lakes. Journal of Phycology 7, 321-329.

Schindler, D.W., 1977. Evolution of Phosphorus Limitation in Lakes. Science 195, 260 262.

Schindler, D.W., 1987. Detecting ecosystem to responses anthropogenic stress. Canadian Journal of Fisheries and Aquatic Sciences 44, 6-25.

Schindler, D.W., 1990. Experimental Perturbations of Whole Lakes as Tests of Hypotheses concerning Ecosystem Structure and Function. Oikos 57, $25-41$.

Schindler, D.W., 1997. Widespread effects of climatic warming on freshwater ecosystems in North America. Hydrological Processes 11, 1043-1067.

Schindler, D.W., 2001. The cumulative effects of climate warming and other human stresses on Canadian freshwaters in the new millennium. Canadian Journal of Fisheries and Aquatic Sciences 58, 18-29.

Schindler, D.W., 2006. Recent advances in the understanding and management of eutrophication. Limnology and Oceanography 51, 356-363.

Schindler, D.W., 2012. The dilemma of controlling cultural eutrophication of lakes. Proceedings of the Royal Society B: Biological Sciences 279, 4322-4333.

Schindler, D.W., Armstrong, F.A.J., Holmgren, S.K., Brunskill, G.J., 1971. Eutrophication of Lake 227, Experimental Lakes Area, Northwestern Ontario, by Addition of Phosphate and Nitrate. Journal Fisheries Research Board of Canada 28, 1763-1782.

Schindler, D.W., Bayley, S.E., Parker, B.R., Beaty, K.G., Cruikshank, D.R., Fee, E.J., Schindler, E.U., Stainton, M.P., 1996. The effects of climatic warming on the properties of boreal lakes and streams at the Experimental Lakes Area, northwestern Ontario. Limnology and Oceanography 41, 1004-1017.

Schindler, D.W., Hecky, R.E., Findlay, D.L., Stainton, M.P., Parker, B.R., Paterson, M.J., Beaty, K.G., Lyng, M., Kasian, S.E.M., 2008. Eutrophication of lakes cannot be controlled by reducing nitrogen input: Results of a 37-year whole-ecosystem experiment. Proceedings of the National Academy of Sciences of the United States of America 105, 11254-11258. 
Scott, M.C., Helfman, G.S., 2001. Native Invasions, Homogenization, and the Mismeasure of Integrity of Fish Assemblages. Fisheries 26, 6-15.

Sereda, J., Bogard, M., Hudson, J., Helps, D., Dessouki, T., 2011. Climate warming and the onset of salinization: Rapid changes in the limnology of two northern plains lakes. Limnologica 41, 1-9.

Setter, T.., Greenway, H., Kuo, J., 1982. Inhibition of Cell Division by High External $\mathrm{NaCl}$ Concentrations in Synchronized Cultures of Chlorella emersonii. Functional Plant Biology 9, 179.

Sieracki, C.K., Sieracki, M.E., Yentsch, C.S., 1998. An imaging-in-flow system for automated analysis of marine microplankton. Marine Ecology Progress Series 168, 285-296.

Simon, K.S., Townsend, C.R., 2003. Impacts of freshwater invaders at different levels of ecological organisation, with emphasis on salmonids and ecosystem consequences. Freshwater Biology 48, 982-994.

Slavik, K., Peterson, B.J., Deegan, L.A., Bowden, W.B., Hershey, A.E., Hobbie, J.E., 2004. Long-term responses of the Kuparuk river ecosystem to phosphorus fertilization. Ecology 85, 939-954.

Smith, V.H., 2003. Eutrophication of freshwater and coastal marine ecosystems: A global problem. Environmental Science and Pollution Research 10, 126-139.

Smol, J.P., 2010. The power of the past: Using sediments to track the effects of multiple stressors on lake ecosystems. Freshwater Biology 55, 43-59.

Søballe, D.M., Kimmel, B., 1987. A Large-Scale Comparison of Factors Influencing Phytoplankton Abundance in Rivers, Lakes, and Impoundments. Ecology 68, $1943-$ 1954.

Soininen, J., 2007. Environmental and spatial control of freshwater diatoms - a review. Diatom Research 22, 473-490.

Soininen, J., Weckström, J., 2009. Diatom community structure along environmental and spatial gradients in lakes and streams. Fundamental and Applied Limnology 174, 205-213.

Sommer, U., Gliwicz, Z.M., Lampert, W., Duncan, A., 1986. The PEG-model of seasonal succession of planktonic events in fresh waters. Archiv für Hydrobiologie 106, 433-471.

Søndergaard, M., Larsen, S.E., Jørgensen, T.B., Jeppesen, E., 2011. Using chlorophyll-a and cyanobacteria in the ecological classification of lakes. Ecological Indicators $11,1403-1412$. 
Sonnenburg, E.P., Boyce, J.I., Reinhardt, E.G., 2009. Multi-proxy paleoenvironmental record of colonial land-use change in the lower Rideau Canal system (Colonel By Lake), Ontario, Canada. Journal of Paleolimnology 42, 515-532.

Soranno, P.A.A., Hubler, S.L.L., Carpenter, S.R.R., Lathrop, R.C.C., 1996. Phosphorus Loads to Surface Waters: A Simple Model to Account for Spatial Pattern of Land Use. Ecological Applications 6, 865-878.

Sosiak, A., 2002. Long-term response of periphyton and macrophytes to reduced municipal nutrient loading to the Bow River (Alberta, Canada). Canadian Journal of Fisheries and Aquatic Sciences 59, 987-1001.

Sparks, R.E., 1995. Need for ecosystem management of large rivers and their floodplains. BioScience 45, 168-182.

Stammler, K.L., Taylor, W.D., Mohamed, M.N., 2017. Long-term decline in stream total phosphorus concentrations: A pervasive pattern in all watershed types in Ontario. Journal of Great Lakes Research 43, 930-937.

Statistics Canada. 1996. Census of Population, Statistics Canada Catalogue no. 93F0032XDB96018.

Statistics Canada. 2017. Ottawa, CV [Census subdivision], Ontario and Canada [Country] (table). Census Profile. 2016 Census. Statistics Canada Catalogue no. 98-316X2016001.

Stević, F., Čerba, D., Čakalić, I.T., Pfeiffer, T.Ž., Vidaković, J., Mihaljević, M., 2013. Interrelations between Dreissena polymorpha colonization and autotrophic periphyton development - A field study in a temperate floodplain lake. Fundamental and Applied Limnology 183, 107-119.

Strayer, D.L., 1999. Effects of alien species on freshwater mollusks in North America. Journal of the North American Benthological Society 18, 74-98.

Strayer, D.L., Caraco, N.F., Cole, J.J., Findlay, S., Pace, M.L., 1999. Transformation of freshwater ecosystems by bivalves: A case study of zebra mussels in the Hudson River. BioScience 49, 19-27.

Strayer, D.L., Dudgeon, D., 2010. Freshwater biodiversity conservation: Recent progress and future challenges. Journal of the North American Benthological Society 29, $344-358$

Su, G., Logez, M., Xu, J., Tao, S., Villéger, S., Brosse, S., 2021. Human impacts on global freshwater fish biodiversity. Science 371, 835-838.

ter Braak, C.J.F., Prentice, I.C., 1988. A Theory of Gradient Analysis. Advances in Ecological Research 18, 271-317. 
Throndsen, J., 1978. Preservation and storage. In: Sournia, A. (Ed.), Phytoplankton Manual. UNESCO, pp. 69-74.

Thunqvist, E.L., 2004. Regional increase of mean chloride concentration in water due to the application of deicing salt. Science of the Total Environment 325, 29-37.

Tilman, D., 1977. Resource Competition between Plankton Algae: An Experimental and Theoretical Approach. Ecology 58, 338-348.

Timms, R.M., Moss, B., 1984. Prevention of growth of potentially dense phytoplankton populations by zooplankton grazing, in the presence of zooplanktivorous fish, in a shallow wetland ecosystem. Limnology and Oceanography 29, 472-486.

Trenberth, K.E., 2011. Changes in precipitation with climate change. Climate Research 47, 123-138.

United Nations Educational Scientific and Cultural Organization (UNESCO), 2007. Nomination of natural, mixed and cultural properties to the world heritage list Rideau Canal. Decision: 31 COM 8B.35.

Vadeboncoeur, Y., Power, M.E., 2017. Attached Algae: The Cryptic Base of Inverted Trophic Pyramids in Freshwaters. Annual Review of Ecology, Evolution, and Systematics 48, 255-279.

Vadeboncoeur, Y., Vander Zanden, M.J., Lodge, D.M., 2002. Putting the Lake Back Together: Reintegrating Benthic Pathways into Lake Food Web Models.

BioScience 52, 44-54.

Van Meter, R.J., Swan, C.M., Leips, J., Snodgrass, J.W., 2011. Road salt stress induces novel food web structure and interactions. Wetlands 31, 843-851.

Vance, B.D., 1965. Composition and Succession of Cyanophycean Water Blooms. Journal of Phycology 1, 81-86.

Vander Zanden, M.J., Vadeboncoeur, Y., 2020. Putting the lake back together 20 years later: what in the benthos have we learned about habitat linkages in lakes? Inland Waters 1-17.

Vanni, M.J., Temte, J., 1990. Seasonal patterns of grazing and nutrient limitation of phytoplankton in a eutrophic lake. Limnology and Oceanography 35, 697-709.

Vannote, R.L., Minshall, G.W., Cummins, K.W., Sedell, J.R., Cushing, C.E., 1980. The River Continuum Concept. Canadian Journal of Fisheries and Aquatic Sciences 37, 130-137.

Vidal, M., Hamilton, P.B., Pick, F.R., 2004. Zebra mussel (Dreissena polymorpha) veliger larvae: Distribution and relationship to phytoplankton biomass and composition in the Rideau River, Ontario, Canada. Archiv fur Hydrobiologie 161, $113-131$. 
Vitousek, P.M., D’Antonio, C.M., Loope, L.L., Westbrooks, R., 1996. Biological invasions as global environmental change. American Scientist 84, 468-478.

Walling, D.E., 1999. Linking land use, erosion and sediment yields in river basins. Hydrobiologia 410, 223-240.

Walsh, J.R., Carpenter, S.R., Van Der Zanden, M.J., 2016. Invasive species triggers a massive loss of ecosystem services through a trophic cascade. Proceedings of the National Academy of Sciences of the United States of America 113, 4081-4085.

Walsh, M.G., Dittman, D.E., O'Gorman, R., 2007. Occurrence and food habits of the round goby in the profundal zone of southwestern Lake Ontario. Journal of Great Lakes Research 33, 83-92.

Watson, K.W., 2006. Engineered landscapes: the Rideau Canals' transformation of a wilderness waterway. Elgin, Ontario.

Watson, K.W., 2007. The Rideau Route: Exploring the pre-canal waterway. Ken W. Watson, Elgin, Ontario.

Webb, D.J., Burnison, B.K., Trimbee, A.M., Prepas, E.E., 1992. Comparison of Chlorophyll-a Extractions with Ethanol and Dimethyl Sulfoxide/Acetone, and a Concern about Spectrophotometric Phaeopigment Correction. Canadian Journal of Fisheries and Aquatic Sciences 49, 2331-2336.

Weijters, M.J., Janse, J.H., Alkemade, R., Verhoeven, J.T.A., 2009. Quantifying the effect of catchment land use and water nutrient concentrations on freshwater river and stream biodiversity. Aquatic Conservation: Marine and Freshwater Ecosystems $19,104-112$.

Wetzel, R.G., 2001. Limnology: Lake and river ecosystems, 3rd ed. Elsevier, San Diego, CA.

Wetzel, R.G., Likens, G.E., 2000. Limnological Analyses, 3rd ed. Springer-Verlag, New York, NY.

Whitton, B.A., Kelly, M.G., 1995. Use of algae and other plants for monitoring rivers. Australian Journal of Ecology 20, 45-56.

Wickham, H., 2016. ggplot2: Elegant graphics for data analysis, Springer. SpringerVerlag, New York, NY.

Williams, D.D., Williams, N.E., Cao, Y., 1999. Road salt contamination of groundwater in a major metropolitan area and development of a biological index to monitor its impact. Water Research 34, 127-138.

Williams, W.D., 1987. Salinization of rivers and streams: an important environmental hazard. Ambio 16, 180-185. 
Williams, W.D., 2001. Anthropogenic salinisation of inland waters. Hydrobiologia 466, 329-337.

Wilson, K.A., Magnuson, J.J., Lodge, D.M., Hill, A.M., Kratz, T.K., Perry, W.L., Willis, T. V., 2004. A long-term rusty crayfish (Orconectes rusticus) invasion: Dispersal patterns and community change in a north temperate lake. Canadian Journal of Fisheries and Aquatic Sciences 61, 2255-2266.

Wilson, S.J., Ricciardi, A., 2009. Epiphytic macroinvertebrate communities on Eurasian watermilfoil (Myriophyllum spicatum) and native milfoils Myriophyllum sibericum and Myriophyllum alterniflorum in eastern North America. Canadian Journal of Fisheries and Aquatic Sciences 66, 18-30.

Winter, J.G., Desellas, A.M., Fletcher, R., Heintsch, L., Morley, A., Nakamoto, L., Utsumi, K., 2011a. Algal blooms in Ontario, Canada: Increases in reports since 1994. Lake and Reservoir Management 27, 107-114.

Winter, J.G., Landre, A., Lembcke, D., O'Connor, E.M., Young, J.D., 2011b. Increasing chloride concentrations in Lake Simcoe and its tributaries. Water Quality Research Journal of Canada 46, 157-165.

Wintermans, J.F.G.M., De Mots, A., 1965. Spectrophotometric characteristics of chlorophylls $\mathrm{a}$ and $\mathrm{b}$ and their phenophytins in ethanol. BBA - Biophysics Including Photosynthesis 109, 448-453.

Withers, P.J.A., Lord, E.I., 2002. Agricultural nutrient inputs to rivers and groundwaters in the UK: Policy, environmental management and research needs. Science of the Total Environment 282-283, 9-24.

Wolman, M.G., Schick, A.P., 1967. Effects of construction on fluvial sediment, urban and suburban areas of Maryland. Water Resources Research 3, 451-464.

Woolway, R.I., Merchant, C.J., 2019. Worldwide alteration of lake mixing regimes in response to climate change. Nature Geoscience 12, 271-276.

World Wide Fund For Nature (WWF), 2020. Living Planet Report 2020. Bending the curve of biodiversity loss: a deep dive into freshwater. Gland, Switzerland.

Wu, N., Schmalz, B., Fohrer, N., 2014. Study progress in riverine phytoplankton and its use as bio-indicator - a review. Austin J. Hydrol 1, 1-9.

Yang, J.R., Basu, B.K., Hamilton, P.B., Pick, F.R., 1997. The development of a true riverine phytoplankton assemblage along a lake-fed lowland river. Archiv fuir Hydrobiologie 140, 243-260.

Zhang, H., Chen, R., Li, F., Chen, L., 2015. Effect of flow rate on environmental variables and phytoplankton dynamics: results from field enclosures. Chinese Journal of Oceanology and Limnology 33, 430-438. 
Zhu, B., Eppers, M.E., Rudstam, L.G., 2008. Predicting invasion of European frogbit in the finger lakes of New York. Journal of Aquatic Plant Management 46, 186-189.

Zhu, B., Kopco, J., Rudstam, L.G., 2015. Effects of invasive European frogbit and its two physical control methods on macroinvertebrates. Freshwater Science 34, 497-507. 


\section{APPENDICES}

Table 7-1. Abbreviated names of phytoplankton sub-groups used in PCA plot (Figure 46).

\begin{tabular}{|c|c|c|}
\hline$\overline{\text { Class }}$ & Sub-Group Name & Abbreviation \\
\hline \multirow{5}{*}{ Bacillariophyceae } & Aulacoseira spp. & B. Aula. \\
\hline & Cocconeis spp. & B. Coc. \\
\hline & Cyclotella spp. & B. Cyc. \\
\hline & Pennate & B. Pen. \\
\hline & Other & B. Spp. \\
\hline \multirow{9}{*}{ Chlorphyceae } & Ankyra spp. & Ch. Ank. \\
\hline & Blue Cluster & Ch. Spp2. \\
\hline & Spheres & Ch. Sing. \\
\hline & Cluster & Ch. Col. \\
\hline & Pediastrum spp. & Ch. Ped. \\
\hline & Sphaerocystis spp. & Ch. Sph. \\
\hline & Tetrastrum spp. & Ch. Tet. \\
\hline & Other & Ch. Spp. \\
\hline & Yellow Dots & Ch. Spp3. \\
\hline Chrysophyceae & Dinobyron spp. & Cs. Din. \\
\hline \multirow{3}{*}{ Cryptophyceae } & Plagioselmis spp. & Cr. Pla. \\
\hline & Cryptomonas reflexa & Cr. Ref. \\
\hline & Other & Cr. Spp. \\
\hline \multirow{6}{*}{ Cyanophyceae } & Aphanothece spp. & Cy. Aph. \\
\hline & Beaded & Cy. Sppl. \\
\hline & Cylinder & Cy. Spp2. \\
\hline & Dolichospermum spp. & Cy. Dol. \\
\hline & Filament & Cy. Spp3. \\
\hline & Microcystis spp. & Cy. Mic. \\
\hline \multirow{2}{*}{ Dinophyceae } & Ceratium hirundinella & D. Cer. \\
\hline & Gymnodinium spp. & D. Gym. \\
\hline Trebouxiophyceae & Geminella spp. & T. Gem. \\
\hline Zygnematophyceae & Staurastrum spp. & Z. Sta. \\
\hline
\end{tabular}

